\title{
NISTIR 3973
}

\section{A BIBLIOGRAPHY OF THE NIST ELECTROMAGNETIC FIELDS DIVISION PUBLICATIONS}

Edited by

Ruth Marie Lyons Kathryn A. Gibson

IC

100 56 3973 991 



\section{A BIBLIOGRAPHY OF THE NIST ELECTROMAGNETIC FIELDS DIVISION PUBLICATIONS}

\section{Edited by}

Ruth Marie Lyons

Kathryn A. Gibson

\section{Electromagnetic Fields Division}

Electronics and Electrical Engineering Laboratory

National Institute of Standards and Technology

Boulder, Colorado 80303-3328

August 1991

(Supersedes NISTIR 89-3945)

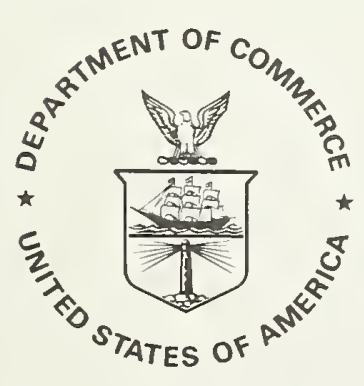

U.S. DEPARTMENT OF COMMERCE, Robert A. Mosbacher, Secretary NATIONAL INSTITUTE OF STANDARDS AND TECHNOLOGY, John W. Lyons, Director 

CONTENTS

Page

INTRODUCTION . . . . . . . . . . . . . . . . . . . . 1

ANTENNAS . . . . . . . . . . . . . . . . . . . . . . . . . . . 3

DIELECTRIC MEASUREMENTS. . . . . . . . . . . . . . . . 20

ELECTROMAGNETIC INTERFERENCE . . . . . . . . . . . . . . . . . . . . 24

MICROWAVE METROLOGY. . . . . . . . . . . . . . . . . . . . . 54

NOISE. . . . . . . . . . . . . . . . . . . . . . 71

REMOTE SENSING . . . . . . . . . . . . . . . . . . . . . . 76

TIME DOMAIN. . . . . . . . . . . . . . . . . . . . . 79

WAVEFORM METROLOGY . . . . . . . . . . . . . . . . . . . 81

MISCELLANEOUS. . . . . . . . . . . . . . . . . . . . 88

AUTHOR INDEX . . . . . . . . . . . . . . . . . . . . . . . . . . . 99 



\title{
A BIBLIOGRAPHY OF THE NIST ELECTROMAGNETIC FIELDS DIVISION PUBLICATIONS
}

\author{
Edited by
}

Ruth Marie Lyons and Kathryn A. Gibson

This bibliography lists the publications by the staff of the Electromagnetic Fields Division of the National Institute of Standards and Technology for the period January 1970 through July 1991. It supersedes NISTIR 3945, which listed the publications of the Electromagnetic Fields Division from January 1970 through July 1990. Selected earlier publications from the Division's predecessor organizations are included.

Key words: antennas; dielectric measurements; electromagnetic interference; microwave metrology; microwave power, impedance, attenuation; near-field antenna measurements; noise; nonionizing radiation; radiation hazards; standards; time domain; waveform metrology.

\section{INTRODUCTION}

The Electromagnetic Fields Division was formed during the reorganization of NIST (formerly NBS) in April 1978. Originally, the Division developed measurement methods and standards, and provided metrological support for antenna systems, noise measurement equipment, fast pulse waveforms, electromagnetic interference, electromagnetic environmental characterization equipment, electromagnetic emission and immunity (or susceptibility) testing equipment, and especially for fields near sources or in other complicated field conditions. In April 1985, microwave and millimeter wave metrology was added to the Division.

The editors have attempted to include all work published by the Division staff in the period from January 1970 through July 1991. Work performed by authors before joining this Division or work by authors who have left this Division has been included only when it had special significance. A miscellaneous category includes general publications. A few references are listed in more than one category where appropriate.

Several other information sources may be useful to the reader who is interested in NIST activities connected with electromagnetic metrology. A companion bibliography, NISTIR 3972, lists publications of the Electromagnetic Technology Division for the same period. Topics include metrology for laser systems, optical fibers, optical communication equipment, cryoelectronics, superconductors, and other unusual electrical 
engineering materials. Three additional bibliographies list publications of the former Electromagnetics Division: NBSIR 73-320 (July 1972-June 1973); NBSIR 74-395 (July 1973-June 1974); NBSIR 75-818 (July 1974-June 1975). These were preceded by a series of unpublished reports (edited by H. M. Altschuler) that cover the period back to 1956. An excellent summary of the whole field of electromagnetic metrology as it stood in 1967 was published as a special issue of the IEEE Proceedings (volume 55, June 1967). Advances in the following decades were described in two other special issues of the same journal (volume 66, April 1978 and volume 74, January 1986).

\section{A Note on Abbreviations}

NOTE: On August 23, 1988, the National Bureau of Standards (NBS) became the National Institute of Standards and Technology (NIST); therefore, documents with either prefix are considered NIST publications. Most readers are familiar with the commonly used abbreviations for the names of the professional journals that appear in this bibliography. Some publication series are peculiar to NIST and may call for explanation. They are:

NISTIR - NIST Interagency/Internal Report NIST Tech. Note - NIST Technical Note NIST SP - NIST Special Publication NIST HB - NIST Handbook NIST JRES - NIST Journal of Research NIST MN - NIST Monograph
NBSIR - NBS Interagency/Internal Report NBS Tech. Note - NBS Technical Note NBS SP - NBS special Publication NBS HB - NBS Handbook NBS JRES - NBS Journal of Research NBS MN - NBS Monograph

Purchase Procedures and Document Availability

NIST (NBS) Technical Notes, Special Publications, Handbooks, Journals of Research, and Monographs may be purchased from the superintendent of Documents, U. S. Government Printing office, Washington, DC 20402. Orders must be accompanied by postal money order, express money order, or check made out to the superintendent of Documents.

NIST (NBS) Interagency/Internal Reports (NISTIRs, NBSIRs) may be purchased from the National Technical Information Service, Springfield, VA 22161. Orders must be accompained by postal money order, express money order, or check made out to NTIS.

Reprints of papers published in non-NIST media may be available in limited quantities from the authors. 


\section{ANTENNAS}

BAIRD, R. C.

Microwave Antenna Measurement Services at the National Bureau of Standards

Dig., Antenna Meas. Tech. Assn. Mtg. October 1981

BAIRD, R. C.; ESTIN, A. J.

The Orbiting Standards Package: A Recalibratable Satellite Instrument Assembly for Measuring Large Earth Station Antennas

Proc., 1982 Antenna Meas. Techniques Assoc., 5-7 October, 1982, New Mexico State University, Las Cruces, NM, pp. 5-1 - 5-9 1982

BAIRD, R. C.; KERNS, D. M.

The Accurate Determination of Millimeter-Wave Antenna Characteristics by Deconvolution and Extrapolation Techniques

Proc., 1974 Milimeter-Wave Conf., 26-28 March, 1974, Vol. 2,

E 2-1 through E 2-12 1974

BAIRD, R. C.; NEWELL, A. C.; STUBENRAUCH, C. F .

A Brief History of Near-Field Measurements of Antennas at the National Bureau of Standards

IEEE Trans. on Antennas and Propagat., Spec. Issue on Near-Field Scanning Techn., Vol. 36, No. 6, pp. 727-733 June 1988

BAIRD, R. C.; DAYWITT, W. C.; NEWELI, A. C.; PERERA, S.; REPJAR, A. G.; WAIT, D. F.; ESTIN, A. J.

Calibration Requirements for EHF satellite Communication systems NBSIR 86-3058

October 1986

BENSEMA, W. D.

Broadband Orthogonal Array Antenna System: Microprocessor Control and Computation Record, "EMC '81," 1981 IEEE Int. Symp. on Electromagn. Compat., 18-20 August, 1981, Boulder, CO 1981

Handbook for Broadband Isotropic Antenna System Volume 1 - Operations Manual

$$
\begin{array}{ll}
\text { NBSIR } & 83-1693 \\
\text { July } 1983
\end{array}
$$

BUSSEY, H. E.; LARSEN, E. B.

Buried Antenna Performance: Development of Small Resonant Buried Antennas

RADC-TR-74-169M, AD 783274

June 1974

CAMELL, D. G.; LARSEN, E. B.; CRUZ, J. E.; HILL, D. A.

NIST Calibration Procedure for Vertically Polarized Monopole Antennas, $30 \mathrm{kHz}$ to $300 \mathrm{MHz}$

NIST Tech Note 1347

January 1991

CRAWFORD, M. L.

Calibration of Broadbeam Antennas Using Planar Near-Field Measurements Proc., 1976 Conf. on Precision Electromagn. Meas.,

28 June-1 July, 1976, Boulder, CO, pp. 53-56 1976 
CRUZ, J. E.; LARSEN, E. B.

Screenroom Measurements of Antenna Factors

Proc., 1985 Instrum. and Meas. Technol. Conf., 20-22 March, 1985, Tampa, FL, p. 208 1985

DAY, G. W.; STUBENRAUCH, C. F.

Laser Far-Field Beam-Profile Measurements by the Focal Plane Technique NBS Tech. Note 1001 March 1978

DAYWITT, W. C.

Error Equations Used in the NBS Precision G/T Measurement system NBSIR 76-842

September 1976

A Precision Earth-Terminal system for Accurate C/KT, G/T, and EIRP Measurements with a Calibrated Radio Star

Proc., 1977 URSI Int. Symp. on Meas. in Telecommunications, 3-7

October, 1977, Lannion, France, pp. 1-4 1977

Error Equations Used in the NBS Earth-Terminal Measurement System NBSIR 78-869

December 1977

Atmospheric Propagation Equations Used in the NBS Earth Terminal

Measurement System

NBSIR 78-883

April 1978

An Error Analysis for the Measurement of Satellite EIRP using a Calibrated Radio star

IEEE Trans. Instrum. Meas., Vol. IM-27, No. 3, pp. 253-258 September 1978

An Error Analysis for the Use of Presently Available Lunar Radio Flux Data in Broadbeam Antenna-system Measurements

NBS Tech. Note 1973

February 1984

A Preliminary Investigation into using the Sun as a source for G/T Measurements

NBSIR 84-3015

August 1984

A Simple Technique for Determining Joint Losses on a Coaxial Line from Swept-Frequency Reflection Data

IEEE Trans. on Instrum. and Meas., Vol. IM-36, pp. 468-473 June 1987

DAYWITT, W. C.; RANDA, M.

G/T Measurement Errors with Radio stars

Proc., 1975 IEEE Int. Antennas and Propagat. Symp., 2-4 June, 1975, Urbana-Champaign, IL, Session 20, pp. 460-463 1975

DOUGHERTY, H. T.; ESTIN, A. J.; MORGAN, W. L.; WOODRUFF, J. J. The Orbiting standards Platform Proc., 1978 Antenna Applications Symp., 20-22 September, 1978, Urbana-Champaign, IL, pp. 1-9 1978 
ESTIN, A. J.; BAIRD, R. C.

Feasibility study of orbiting standards Platform

NBSIR 78-886

June 1978

ESTIN, A. J.; JANEZIC, M. D.

Improvements in Dielectric Measurements with a Resonant Cavity

Conf. Record, IEEE Instrumentation \& Measurement Technology Conf., May 14-16, 1991, Atlanta, GA, pp. 573-579 May 1991

ESTIN, A. J.; STUBENRAUCH, C. F.; REPJAR, A. G.; NEWELL, A. C.

Optimized Wavelength-Sized Scalar Horns as Antenna Radiation Standards 1981 EEMTIC Dig., June 1981 1981

IEEE Trans. Instrum. Meas., Vol. IM-31, No. 1, pp. 53-56 March 1982

FITZGERRELI, R. G .

A Partial Loop Source of $E$ \& $H$ Fields for Antenna Factor Calibration (A Loop Cell)

Proc., 1982 Antenna Meas. Techniques Assoc., 5-7 October, 1982, New Mexico State University, Las Cruces, NM, pp. 15-1 through 15-22

1982

A Source of E\&H Fields for Antenna-Factor Calibration

IEEE Trans. Electromagn. Compat., Vol. EMC-26, No. 2, pp. 58-65

May 1984

Linear Gain - Standard Antennas Below $1000 \mathrm{MHz}$

NBS Tech. Note 1098

May 1986

Standard Linear Antennas, $30 \mathrm{GHz}$ to $1000 \mathrm{MHz}$

Proc., Conf. on Electromagn. Compat., 29 september-2 October,

1986, University of York, England, pp. 147-153 1986

Three PC-Computer Programs for Antenna Calculations Primarily for Use

Below $1000 \mathrm{MHz}$

IEEE Antennas and Propagat. Soc. (AP-S) Newslett., Vol. 29, No. 3, pp. $30-32$

June 1987

FRANCIS, M. B.

Antenna Far-Field Pattern Accuracies at Millimeter Wave Frequencies

Using the Planar Near-Field Technique.

Proc., Antenna Measurement Techniques Association (AMTA) Symp.;

9-13 October 1989; Monterey, CA; pp. 11-16-11-21.

October 1989

FRANCIS, M. H.; HILI, D. A.

Out-of-Band Response of Array Antennas

Proc., Antenna Meas. Techniques Assoc., 28 September-2 October, 1987, seattle, WA, pp. 14-19 1987 
FRANCIS, M. H.; MACREYNOLDS, K.

Evaluation of Dual-Port Circularly Polarized Probes for Planar NearField Measurements

Proc., 12th Annual Meeting \& Symp., Antenna Msmt. Techniques

Assn. , 8-11 Oct. 1990, Philadelphia, PA, pp. 13-3-13-8 October 1990

FRANCIS, M. H.; STUBENRAUCH, C. F.

Comparison of Measured and Calculated Antenna Side Lobe Coupling Loss in the Near Field Using Approximate Far-Field Data

IEEE Trans. on Antennas and Propagat., Vol. 36, No. 3, pp. 438-441 March 1988

FRANCIS, M. H.; YAGHJIAN, A. D.

Computations of Antenna Side-Lobe Coupling in the Near Field Using

Approximate Far-Field Data

NBSIR $82-1674$

August 1982

FRANCIS, M. H.; REPJAR, A. G.; KREMER, D. P.

Antenna Measurements for Millimeter Waves at the National Bureau of Standards

Proc., Antenna Meas. Techniques Assoc., 12-16 September, 1988, Atlanta, GA, pp. 13-13-13-17

September 1988

FRANCIS, M. B.; RREMER, D. P . ; REPJAR, A. G. Advanced System Characterizes Antennas to $65 \mathrm{GHz}$. Microwaves and RF; pp. 77-88. March 1990

GREENLEE, D. H . ; RANDA, M.; CHANG, D. C.

The Characteristics of Iris-Fed Millimeter Wave Rectangular Microstrip Patch Antennas

NBS Tech. Note 1063

october 1983

GUERRIERI, J . R ; KREMER, D. P.

Automated Multi-Axis Motor Controller and Data Acquisition System for Near-Field Scanners.

Proc., Antenna Measurement Techniques Association (AMTA) Symp.;

9-13 October 1989; Monterey, CA; pp.12-24 - 12-28.

October 1989

HILI, D. A.

Theory of Near-field Phased Arrays for Electromagnetic Susceptibility Testing

NBS Tech. Note 1072

February 1984

Out-of-Band Response of Reflector Antennas

NBSIR 85-3021

April 1985

Far-Field Transient Response of an Antenna from Near-Field Data NBSIR 86-3063

December 1986

Antennas for Geophysical Applications

Antenna Handbook: Theory, Applications and Design (Chapter 3), edited by U. T. Lo and S. W. Lee, Van Nostrand Reinhold Co., pp. 23-1 through 23-6 1988 
HIL工, D. A.; CAVCEY, K. H.

Coupling Between Two Antennas separated by a Planar Interface

IEEE Trans. on Geoscience and Remote Sensing,

Vol. GE-25, No. 4, pp. 422-431 July 1987

HII工, D. A.; EHRET, R. L.

Near-Field Gain of Pyramidal Horns from 18 to $40 \mathrm{GHz}$;

NISTIR 89-3924

November 1989

HIIL, D. A.; FRANCIS, M. H.

Out-of-Band Response of Antenna Arrays

NBSIR 86-3047

June 1986

Proc., 1987 IEEE Int. Symp. on Electromagn. Compat.,

25-27 August, 1987, Atlanta, GA, pp. 435-438 1987

IEEE Trans. on Electromagn. Compat., Vol. EMC-29, No. 4, pp. 282-288

November 1987

HILL, D. A.; ROEPRE, G. H.

A Near-Field Array of Yagi-Uda Antennas for Electromagnetic

Susceptibility Testing

NBS Tech. Note 1082

July 1985

IEEE Trans. on Electromagn. Compat., Vol. EMC-28, No. 4, pp. 273-276

November 1986

An Array of Dipoles for Plane Wave Synthesis

Proc., 1985 Int. Symp. on Antennas and EM Theory,

26-28 August, 1985, Beijing, China, pp. 422-427 1985

HILI, D. A.; WAIT, J.R.

Electromagnetic Characteristics of a Coaxial Cable with Periodic slots

IEEE Trans. Electromagn. Compat., Vol. EMC-22, No. 4,

pp. 303-307

November 1980

JESCH, R. L.

Measured Vehicular Antenna Performance

IEEE Trans. Veh. Technol., Vol. VT-34, No. 2, pp. 97-107 May 1985

National Institute of Justice Technology Program, NIJ Report-201-85

May 1986

RANDA, M.

Accuracy Considerations in the Measurement of the Power Gain of a Iarge Microwave Antenna

Proc., 1974 Int. IEEE/AP-S Symp., 10-12 June, 1974,

Atlanta, GA, pp. 43-45

1974 
KANDA, M. (cont.)

Accuracy Considerations in the Measurement of the Power Gain of a Large Microwave Antenna

IEEE Trans. Antennas Propagat., Vol. AP-23, No. 3, pp. 407-411

May 1975

Study of Error Analysis for Absolute Flux Density Measurements of Cassiopeia

IEEE Trans. Instrum. Meas., Vol. IM-25, No. 3, pp. 173-182

September 1976

A Relatively short Cylindrical Broadband Antenna with Tapered Resistive Loading for Picosecond Pulse Measurements

NBSIR 77-861

August 1977

IEEE Antennas and Propagat. Soc. Dig., pp. 230-233

May 1978

IEEE Trans. Antennas and Propagat., Vol. AP-26, No. 3, pp. 439-447

May 1978

Transients in Resistively Loaded Antennas and Their Comparison with Conical Antennas and TEM Horns

NBSIR 78-876

March 1978

IEEE Trans. Antennas Propagat., Vol. AP-28, No. 1, pp. $132-136$

January 1980

Analytical and Numerical Techniques for Analyzing an Electrically short Dipole with a Nonlinear Load

NBSIR 78-898

November 1978

IEEE Trans. Antennas Propagat., Vol. AP-28, No. 1, pp. 71-78 January 1980

The Time Domain Characteristics of a Traveling Wave Linear Antenna with Linear and Non-Linear Loads

NBSIR $78-892(R)$

February 1979

The Effects of Resistive Loading on TEM Horns

NBSIR 79-1601

August 1979

The Characteristics of a Linear Antenna with Tapered Resistive and Capacitive Loading

Proc., 1980 IEEE AP Symp., 2-6 June, 1980, Quebec, Canada, Vol. 2, AP. 18-2, pp. 696-699 1980 
RANDA, M. (cont.)

The Effects of Resistive Loading on TEM Horns

IEEE Trans. Electromagn. Compat., Vol. EMC-24, No. 2, pp. 245-255

May 1982

An Electromagnetic Near-Field Sensor for simultaneous Electric and Magnetic-Field Measurements IEEE Trans. Electromagn. Compat., Vol. EMC-26, No. 3, pp. 102-110 August 1984

Transients in a Resistively Loaded Loop Antenna Proc., 1984 Int. Symp. on Electromagn. Compat., 16-18 October, 1984, Tokyo, Japan, Vol. 1, pp. 286-290 1984

RANDA, M.; ORR, R. D.

Near-Field Gain of a Horn and an Open-Ended Waveguide; Comparison Between Theory and Experiment

IEEE AP/S Symp. on Antennas and Propagation

8-13 June, 1986, Philadelphia, PA, pp. 91-94 1986

Proc., 5th Int. Conf. on Electromagn. Compat., 29 september-

2 October, 1986, University of York, England, pp. 137-145 1986

IEEE Trans. on Antennas and Propagat., Vol. AP-35, No. 1, pp. $33-40$

January 1987

RANDA, M.; CHANG, D. C.; GREENLEE, D. H.

The Characteristics of Iris-Fed Millimeter Wave Rectangular Microstrip Patch Antennas

Proc., 1982 IEEE AP/S Symp., 24-28 May, 1982, University of New Mexico, Albuquerque, NM, pp. 292-295 1982

RERNS, D. M.

Comment on Correction of Errors in Aerial Far-Field Radiation-Pattern Determinations

Electronics Letters, Vol. 7 , No. 24, pp. 706 December 1971

Plane-Wave Scattering Matrix Theory of Antennas and Antenna-Antenna Interactions: Formulation and Applications NBSIR 75-824 January 1975

Plane-Wave Scattering Matrix Theory of Antennas and Antenna-Antenna Interactions

NBS MN 162

June 1981 
KREMER, D. P.; NEWELL, A. C.

Alignment Fixture for Millimeter Waveguide

IEEE Antennas \& Propagation Magazine, Vol. 3, No. 3, pp. 45-48 June 1990

KREMER, D. P.; REPJAR, A. G.

Antenna Calibrating Standards Using CW and Pulsed-CW Measurements and the Planar Near-Field Method

Proc., Antenna Meas. Techn. Assoc., 12-16 September, 1988,

Atlanta, GA, pp. 13-21-13-29

September 1988

KREMER, D. P.; NEWELL, A. C.; AGEE, D. A.

Absorber Characterization.

Proc., Antenna Measurement Techniques Association (AMTA) Symp.;

9-13 October 1989; Monterey, CA; pp.13-7 - 13-11.

October 1989

LARSEN, E. B.

Calibration and Meaning of Antenna Factor and Gain for EMI Antennas

Interference Technology Engineers' Master (ITEM 1986),

pp. $113-335$

1986

LARSEN, E. B.; ANDREWS, J.R.

Using Fiber Optics in a Broadband, Sensitive, Isotropic Antenna -

$15 \mathrm{kHz}$ to $150 \mathrm{MHz}$

Proc., IEEE Int. Symp. on Electromagn. Compat.,

13-15 July, 1976, Washington, DC, pp. 385-389 1976

LARSEN, E. B.; CRUZ, J.E.

E\&H Fields in Transmission Lines and Coils for susceptibility Testing,

Probe Calibration, and RF Exposure Chambers

Proc., 1985 Instrum. and Meas. Technol. Conf.,

20-22 March, 1985, Tampa, FL, p. 199

1985

IAWTON, R. A.; ONDREJRA, A. R.

Antennas and the Associated Time Domain Range for the Measurement of Impulsive Fields

NBS Tech. Note 1008

November 1978

LEWIS, R. I.

The Use of Three Term Recursion Relations for Numerical Computations as Applied to Near-Field Spherical Scanning

Proc., Int. Union of Radio Science (URSI) Int. Symp.,

20-24 June, 1977, pp. 224-226

1977

Efficient Computation of the Far-Field Radiated by an Arbitrary Rectangular-Aperture Distribution

NBSIR 81-1643

April 1981 
LEWIS, R. L. (cont.)

Spherical Scanning Data Processing: An Algorithm for Halving the Data Processing Effort when the Radiation into the Back Hemisphere is Negligible

$$
\text { Dig., } 1981 \text { IEEE APS Int. Symp., June } 1981
$$

Spherical-Wave Source-Scattering-Matrix Analysis of the Mutual Coupling Between Two Antennas

Dig., 1981 IEEE AP-S Int. Symp.

June 1981

Spherical-Wave Source-Scattering Matrix Analysis of Coupled Antennas; A General system Two-Port solution

IEEE Trans. on Antennas and Propagat., Vol. AP-35, No. 12, pp. 1375-1380

December 1987

LEWIS, R. L.; NEWELI, A. C.

Efficient and Accurate Method for Calculating and Representing Power

Density in the Near Zone of Microwave Antennas IEEE Trans. on Antennas \& Propag., Spec. Issue, Near-Field

Scanning Techn., Vol. 36, No. 6, pp. 890-891 June 1988

LEWIS, R. I.; WITTMANN, R. C.

Improved Spherical and Hemispherical Scanning Algorithms

IEEE Trans. on Antennas and Propagat., Vol. AP-35, No. 12, pp. 1381-1388

December 1987

MA, M. T.

A Theoretical Study of Unbalanced Ground Effects on Receiving Dipoles NBSIR 79-1605

May 1979

Synthesis of Broadband Antenna Arrays as Possible Over-the-Horizon

Radars Research Topics in EM Wave Theory (Chapter 9)

John Wiley Interscience, pp. 188-209 1981

Arrays of Discrete Elements

Antenna Engineering Handbook, Chapter 3, R. C. Johnson and H. Jasik, MCGraw-Hill Book Co. January 1984

MUTH, L. A.

Mutual Impedances and Multiple Reflections in an $\mathbf{N}-$ Element Array

Environment NBS Tech. Note 1078

February 1985

A Theory of Mutual Impedances and Multiple Reflections in an N-Element Array Environment

Proc., 1985 Int. Symp. on Antennas and Propagat.,

20-22 August, 1985, Kyoto, Japan, pp. 719-722

1985 
MUTH, I. A. (cont.)

A Theory of Mutual Impedances and Multiple Reflections in an N-Element Array Environment

Proc., 1985 Int. Symp. on Antennas and EM. Theory,

26-28 August, 1985, Beijing, China, pp. 440-443 1985

Interelement Interactions in Phased Arrays: Theory, Methods of Data Analysis, and Theoretical Simulations

NBS Tech. Note 1091

December 1985

Gradient Displacement Errors in Antenna Near-Field Measurements and Their Effects on the Far Field

NBS Tech. Note 1306

October 1986

Experimental study of Interpanel Interactions at $3.3 \mathrm{GHz}$ Proc., Antenna Meas. Techniques Assoc.,

28 September-2 October, 1987, Seattle, WA, pp. 25-29 1987

Displacement Errors in Antenna Near-Field Measurements and Their Effect on the Far Field

IEEE Trans. on Antennas and Propagat., Vol. 36, No. 5, pp. 581-591

May 1988

MUTH, I. A.; LEWIS, R. L.

An Iterative Technique to Correct Probe Position Errors in Planar

Near-Field to Far-Field Transformations

NIST TN-1323

October 1988

Planar Near-Field Codes for Personal Computers; NISTIR 89-3929

October 1989

An Iterative Technique to Correct Probe Position Errors in Planar Near-Field to Far-Field Transformations.

Proc., 1989 Int. Symp. on Antennas and Propagat.; 22-25 August 1989; Nagoya, Japan; pp. 901-904.

August 1989

A General Technique to Correct Probe Position Errors in Planar NearField Measurements to Arbitrary Accuracy

IEEE Trans. on Antennas and Propagat., Vol. 38, No. 12, pp. 19251932

December 1990

MUTH, L. A.; NEWELL, A. C.; LEWIS, R. L.; CANALES, S ; KREMER, D. P. Experimental \& Theoretical Probe Position Error Correction in Near-Field Antenna Measurements

Proc., 12th Annual Meeting \& Symp., Antenna Msmt. Techniques

Assn., 8-11 Oct., 1990, Philadelphia, PA, pp. 13-27-13-30 October 1990 
NEWELI, A. C.

Improved Polarization Measurements Using a Modified Three Antenna Technique

Proc., 1975 IEEE Int. Antennas and Propagat. Symp.,

2-4 June, 1975, Urbana-Champaign, IL, Session 15, pp. 337-340 1975

Improved Polarization Measurements Using a Modified Three Antenna Technique

IEEE Trans. on Antennas and Propagat., Spec. Issue on Near-Field Scanning Techn., Vol. 36, No. 6, pp. 852-854 June 1988

Error Analysis Techniques for Planar Near-Field Measurements IEEE Trans. on Antennas and Propagat., Spec. Issue on Near-Field Scanning Techn., Vol. 36, No. 6, pp. 754-768 June 1988

Development of Near-Field Test Procedures for Communication Satellite Antennas, Phase I, Part 2

NBSIR 87-3081

August 1988

NEWELL, A. C.; CRAWFORD, M. L.

Planar Near-Field Measurements on Phased Array Antennas Proc., 1974 Int. IEEE/AP-S Symp., 10-12 June, 1974, Atlanta, GA, (Paper 6-7 in 1974 International IEEE/AP-S Symposium Digest, p. 423) 1974

Planar Near-Field Measurements on High Performance Array Antennas NBSIR $74-380$ July 1974

NEWELL, A. C.; RERNS, D. M.

Determination of Both Polarization and Power Gain of Antennas by a Generalized 3-Antenna Measurement Method

Electronics Letters, Vol. 7, No. 3, pp. 68-70 January 1971

NEWELL, A. C.; REPJAR, A. G.

Results of Spherical Near-Field Measurements on Narrow-Beam Antennas Proc., 1976 Conf. on Precision Electromagn. Meas., 28 June-1 July, 1976, Boulder, CO, pp. 382-385 1976

Development of Near-Field Test Procedures for Communication Satelite Antennas, Phase I, Part 1 NBSIR 85-3031

September 1985

NEWELL, A. C.; STUBENRAUCB, C. F.

The Effect of Random Errors in Planar Near-Field Measurements Proc., 1986 Int. IEEE AP-S Symp., 8-13 June, 1986, Philadelphia, PA, pp. 195-198 1986 
NEWELL, A. C.; STUBENRAUCH, C. F. (cont.)

Effect of Random Errors in Planar Near-Field Measurement IEEE Trans. on Antennas and Propagat., Spec. Issue on Near-Field Scanning Techn., Vol. 36, No. 6, pp. 769-773 June 1988

NEWELL, A. C.; YAGHJIAN, A. D.

Study of Errors in Planar Near-Field Measurements Proc., 1975 IEEE Int. Antennas and Propagat. Symp., 2-4 June, 1975, Urbana-Champaign, IL, Session 20, pp. 470-473 1975

NEWELL, A. C.; BAIRD, R. C.; WACKER, P. F.

Accurate Measurement of Antenna Gain and Polarization at Reduced Distances by an Extrapolation Technique

IEEE Trans. Antennas Propagat., Vol. AP-21, No. 4, pp. $418-431$

July 1973

NEWELL, A. C.; FRANCIS, M. H.; KREMER, D. P.

The Determination of Near-field Correction Parameters for Circularly Polarized Probes

Proc., 1984 Antenna Meas. Techniques Assoc. Conf.,

2-4 October, 1984, Atlanta, GA, pp. 3A3-1 through 3A3-29 1984

NEWELL, A. C.; KREMER, D. P.; GUERRIERI, J. R .

Improvements in Polarization Measurements of Circularly Polarized

Antennas.

Proc., Antenna Measurement Techniques Association (AMTA) Symp.;

9-13 October 1989; Monterey, $\mathrm{CA}_{\text {; }} \mathrm{pp}$. 1-30 - 1-36.

October 1989

NEWELL, A. C.; STUBENRAUCH, C. F.; BAIRD, R. C.

Calibration of Microwave Antenna Gain Standards

Proc. IEEE, Spec. Issue on Radio Meas. Methods and Standards,

Vol. 74, Vol. 1, pp. 129-132

January 1986

NEWELI, A. C.; FRANCIS, M. H.; KREMER, D. P.; GRIMM, K. R .

Results of Planar Near-field Testing with Ultralow Sidelobe Antennas Dig., Int. IEEE/AP-S Symp. on Antennas and Propagat., 17-21 June, 1985, University of British Columbia, Vancouver, Canada, pp. 693-698

1985

NEWELL, A. C.; GUERRIERI, J. R.; PERSINGER, R. R。; STILES, J. A.; MCFARIANE, E. J.

Comparison of Antenna Boresight Measurements Between Near-Field and Far-Field Ranges.

Proc., Antenna Measurement Techniques Association (AMTA) Symp.;

9-13 October 1989; Monterey, CA; pp. 1-24 - 1-29.

October 1989 
REEVE, G. R .

Synthesized Isotropic Pattern Antennas for EM Field Measurements Record, "EMC '81," 1981 IEEE Int. Symp. on Electromagn. Compat., 18-20 August, 1981, Boulder, Co 1981

REEVE, G. R.; WAINWRIGHT, A. E.

A Frequency Tracking, Tuned, Receiving Monopole Record, IEEE/APS Symp., June, 1981 1981

REPJAR, A. G.; RREMER, D. P.

Results of Planar Near-Field Measurements on a Compact Range at 18 and $54 \mathrm{GHz}$

$$
\begin{array}{ll}
\text { Dig., } & \text { IEEE/AP-S Symp. } \\
1980
\end{array}
$$

Accurate Evaluation of a Millimeter Wave Compact Range Using Planar Near-Field Scanning

IEEE Trans. Antennas Propagat., Vol. AP-30, No. 3,

pp. $419-425$

May 1982

REPJAR, A. G.; NEWELL, A. C.; BAIRD, R. C.

Antenna Gain Measurements by an Extended Version of the NBS

Extrapolation Method

Dig., 1982 Conf. on Precision Electromagn. Meas.,

28 June-1 July, 1982, Boulder, CO, pp. F-7 through F-9 1982

IEEE Trans. Instrum. Meas., Vol. IM-32, No. 1, pp. 88-91 March 1983

REPJAR, A. G.; NEWELL, A. C.; FRANCIS, M. H.

Accurate Determination of Planar Near-Field Correction Parameters for Linearly Polarized Probes

IEEE Trans. on Antennas and Propagat., Special Issue on Near-Field Meas., Vol. 36, No. 6, pp. 855-868

June 1988

REPJAR, A. G.; NEWELL, A. C.; TAMURA, D. T.

Extrapolation Range Measurements for Determining Antenna Gain and

Polarization

NBS Tech. Note 1311

August 1987

STUBENRAUCH, C. F.

Some Recent Near-Field Antenna Measurements

Proc., 1979 Antenna Application Symp., September, 1979 1979

STUBENRAUCH, C. F.; FRANCIS, M. H.

Comparison of Measured and Calculated Mutual Coupling in the Near Field Between Microwave Antennas

NBSIR 84-3010

June 1984 
STUBENRAUCH, C. F.; FRANCIS, M. H. (cont.)

Comparison of Measured and Calculated Mutual Coupling in the Near Field Between Microwave Antennas

Proc., 1984 Antenna Applications Symp., 19-21 September, 1984, University of Illinois, Urbana-Champaign, IL, pp. 1-21 1984

STUBENRAUCH, C. F.; YAGHJIAN, A. D.

Determination of Mutual Coupling Between Co-Sited Microwave Antennas and Calculation of Near-Zone Electric Field

NBSIR $81-1630$

June 1981

STUBENRAUCH, C. F.; SPIESS, W.; GALLIANO, P. G.; BABJI, T.

International Intercomparison of Electric Field Strength at $100 \mathrm{MHz}$ Dig., 1982 Conf. on Precision Electromagn. Meas.,

28 June-1 July, 1982, Boulder, CO, pp. P-3 through P-4 1982

TAGGART, H. E.; SHAFER, J. F.

Testing of Electronic Industries Association Land-Mobile Communication

Antenna Gain Standards at the National Bureau of Standards

IEEE Trans. Veh. Technol. VT-27, pp. 259-264

November 1978

TREADO, M. J.; TAGGaRT, H. E.; NELSON, R. E.; WORKMAN, J. L.

Fixed and Base Station Antennas

National Institute of Justice (NIJ) Standard-0204.01 (Supercedes

National Institute for Law Enforcement and Criminal Justice

(NILECJ) STD-0204.00, dated November 1977)

December 1981

WACKER, P. F.

Near-Field Antenna Measurements Using a Spherical Scan: Efficient Data Reduction with Probe Correction

CPEM Dig., No. 113, pp. 286-288 (Institution of Electrical

Engineers, London, England) 1974

Antenna Measurements at the National Bureau of Standards Near-Field and Extrapolation Techniques

Proc., 1974 Colloquium on Microwave Communication (5th),

24-30 June, 1974, Budapest, PME-113-114. 1974

Non-Planar Near-Field Measurements: Spherical Scanning

NBSIR 75-809

1975

Symmetry Analysis Applied to Scattering, Inverse Scattering, and Antenna Patterns: Measurements, Moment Method, and Characteristic Modes Proc., 1977 IEEE/Antennas and Propagat. Soc. Int. Symp., pp. $177-180$

1977

Symmetry Analysis Applied to Wave Theory

Int. IEEE/AP-S Symp. Dig. 1977 
WACKER, P. F. (cont.)

Recent Results with Spherical Near-Field Antenna scanning at the National Bureau of Standards Proc., 1977 European Space Agency Symp., 6-8 June, 1977, Noordwijk (Netherlands), pp. 159-164 1977

A Qualitative Survey of Near-Field Analysis and Measurement NBSIR 79-1602 January 1979

Plane-Radial Scanning Techniques With Probe Correction; Natural Orthogonalities With Respect to Summation on Planar Measurement Lattices Dig. of the IEEE/APS Symp. February 1979

WACKER, P. F.; NEWELL, A. C.

Advantages and Disadvantages of Planar, Circular Cylindrical and Spherical Scanning and Description of the NBS Antenna Scanning Facilities

Proc., 1977 European Space Agency Symp., 6-8 June, 1977, Noordwijk (Netherlands), pp. 115-121

$$
1977
$$

WAIT, D. F.

Satellite Earth Terminal G/T Measurements

Microwave Journal, Vol. 20, No. 4, pp. 49, 51, 58 April 1977

Earth Terminal Measurement System Operations Manual

NBSIR 78-879

April 1978

Precision Measurement of Antenna System Noise Using Radio Stars

Dig., 1982 Conf. on Precision Electromagn. Meas.,

28 June-1 July, 1982, Boulder, CO, p. F-17 1982

IEEE Trans. Instrum. Meas., Vol. IM-32, No. 1, pp. 110-116 March 1983

Earth Terminal Measurement System Operations Manual (Revised) NBSIR 83-1679(R)

January 1983

WAIT, J. R.; HILL, D. A.

Fields of a Horizontal Loop of Arbitrary Shape Buried in a Two-Layer

Earth

Radio Science, Vol 15, No. 5, pp. 903-912

September-October 1980

WILSON, P. F.; CHANG, D. C. ; MA, M. T.

Input Impedance of a Probe Antenna Exciting a TEM Cell

NBS Tech. Note 1054

April 1982 
WITTMANN, R. C.

Probe Correction in Spherical Near-field Scanning Viewed as an Ideal

Probe Measuring an Effective Field

Dig., 1984 Int. Symp. on Antennas and Propagat.,

25-29 June, 1984, Boston, MA, pp. 674-677

1984

Spherical Wave Operators and the Translation Formulas

IEEE Trans. on Antennas \& Propagation, Vol. 36, No. 8, pp.10781087

August 1988

Comments on Spherical Near-Field Antenna Measurements:

Review for AP-S Newsletter, Vol. 31, No. 3, pp. 35-36

June 1989

Spherical Near-Field Scanning: Determining the Incident Field Near a Rotatable Probe.

Proc. Int'l Symp. on Antennas \& Propagation, IEEE;

May 7-11, 1990; Dallas, TX; pp. 224-227

May 1990

Probe-Corrected Spherical Near-Field Scanning Theory in Acoustics

Conf. Record, IEEE Instrumentation/Measurement Technology Conf.; May 14-16, 1991; Atlanta, GA; pp. 283-286

May 1991

WITTMANN, R. C.; STUBENRAUCH, C. F.

Spherical Near-Field Scanning: Experimental and Theoretical Studies NISTIR 3955

July 1990

WYSS, J. C.; SHEERAN, S.

A Passive, Optical Modulator and Link for Antennas

IEEE J. of Lightwave Technol., Vol. LT-3, No. 2, pp. 316-321 April 1985

WYSS, J. C.; ANSON, W. J.; ORR, R. D.

Building Penetration Project NBSIR 84-3009

September 1984

WYSS, J. C.; KANDA, M.; MELQUIST, D. G.; ONDREJKA, A. R.

Optical Modulator and Link for Broadband Antennas

Dig., 1982 Conf. on Precision Electromagn. Meas.,

28 June-1 July, 1982, Boulder, CO, pp. P-16 through P-17

1982

YAGHJIAN, A. D.

Upper-Bound Errors in Far-Field Antenna Parameters Determined from

Planar Near-Field Measurements. Part 1: Analysis

NBS Tech. Note 667

October 1975 
YAGHJIAN, A. D. (cont.)

A Direct Approach to the Derivation of Electric Dyadic Green's Functions AP-Symposium Dig., October, 1976, pp. 76-156 October 1976

NBS Tech. Note 1000

December 1977

Near-Field Antenna Measurements on a Cylindrical Surface: A Source Scattering-Matrix Formulation

NBS Tech. Note 696

september 1977

An Approximate Expression for the Principal Beamwidth of Directive Antennas in Terms of Aperture Fields

NBSIR 81-1644

March 1981

A Delta-Distribution Derivation of the Electric Field in the source Region

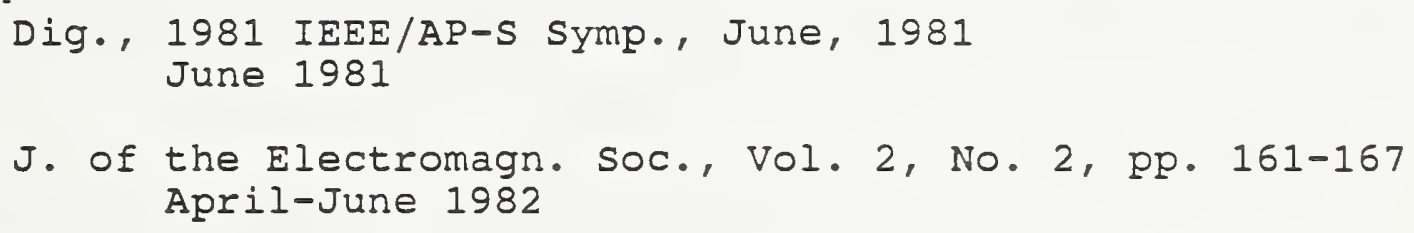

Efficient Computation of Antenna Coupling and Fields Within the Near-Field Region

IEEE Trans. Antennas Propagat., Vol. AP-30, No. 1, pp. $113-128$

January 1982

Approximate Formulas for the Far Field and Gain of Open-Ended

Rectangular Waveguide

NBSIR 83-1689

May 1983

YAGHJIAN, A. D.; WITTMANN, R. C.

The Receiving Antenna as a Linear Differential Operator: Application to Spherical Near-Field Scanning

IEEE Trans. on Antenna and Propagat., Vol. AP-33, No. 11, pp. 1175-1185

November 1985 


\section{DIELECTRIC MEASUREMENTS}

BARER-JARVIS, $J$.

Transmission/Reflection and Short-Circuit Line Permittivity Measurement Methods

$$
\begin{aligned}
\text { NIST TN } 1341 \\
\text { July } 1990
\end{aligned}
$$

BARER-JARVIS, J.; GEYER, R. G . Improved Algorithms for the Transmission/Reflection and short Circuit Permittivity and Permeability Measurement Methods.

Digest, CPEM; June 11-14, 1990; Ottawa, Canada; pp. 232-233. June 1990

BARER-JARVIS, J.; VANZURA, E. J.; KISSICK, W. A.

Improved Technique for Determining Complex Permittivity with the Transmission/Reflection Method

IEEE Trans. on Microwave Theory and Techniques, Vol. 38, No. 8, pp. 1096-1103

August 1990

BENNETT, W. S.; TAGGART, H. E.

Characteristics of A CISPR/VDE Far-Field EMI Test site with Ground screen

Proc., Third Rotterdam Electromagn. Compat. Symp., December 1978

1978

BUSSEY, H. E.

Measurement of RF Properties of Materials, A Survey

Proc. IEEE, Special Issue on Radio Meas. Methods and Standards, Vol. 55, No. 6, pp. 1046-1053

June 1967

Rapport Sur la Comparaison Int.E des Mesures de Permittivite Complexe a

$9 \mathrm{GHz}$ (Int. Comparison of Complex Permittivity Measurement at $9 \mathrm{GHz}$ )

Proc., of Comite Consultatif, D'Electricite Comite, Int. des Poids et Mesures, 12-13 October, 1972, Sevres, France, pp. 124-137 1972

Wavelength of a slotted Rectangular Line Containing Two Dielectrics NBSIR 73-326

July 1973

Dielectric Measurements of Lunar Soil

Proc., 1979 Lunar and Planetary Science Conf. (10th) Nat.

Aeronautics and Space Administration, 19-23 March, 1979,

Lyndon B. Johnson Space Center, Houston, TX 1979

Open Circuited Coaxial Resonator for High Sensitivity Dielectric Measurements, Application to Lunar Soil 70051-20 Proc., 1979 Lunar and Planetary Science Conf. (10th) Nat. Aeronautics and Space Administration, 19-23 March, 1979, Lyndon B. Johnson Space Center, Houston, TX 1979

Dielectric Measurements in a Shielded Open Circuit Coaxial Iine IEEE Trans. Instrum. Meas., Vol. IM-29, No. 2 June 1980 
BUSSEY, H. E . R R CHMOND, J . H .

scattering by a Lossy Dielectric Circular Cylindrical Multilayer, Numerical Values

IEEE Trans. Antennas Propagat., Vol. 23, No. 5, pp. 723-725 September 1975

BUSSEY, H. E.; MORRIS, D.; ZALTSMAN, E. B. International Comparison of Complex Permittivity Measurement at 9 GHz IEEE Trans. Instrum. Meas., Vol. IM-23, No. 3, pp. 235-239

september 1974

DAYWITT, W. C.

Complex Permittivity of Beryllium Oxide Between 100 and 300 Kelvins at 9.3 Gigahertz

IEEE Trans. Instrum. Meas., Vol. IM-34, No. 1, pp. 98-99 March 1985

ELLERBRUCH, D. A.; LITTLE, W. E.; BOYNE, H. S.; BACHMAN, D. D. Microwave Characteristics of Snow Proc., 1977 Western Snow Conf., 18-21 April, 1977, Albuquerque, NM, p 7 . 1977

GEYER, R. G .

Dielectric Mixing Rules for Background Test Soils

NBSIR 88-3095

June 1988

Electrodynamics of Materials for Dielectric Measurement Standardization. Record, Instrumentation \& Measurement Technology (IMTC) Conf.;

February 13-15, 1990; San Jose, CA; pp. 2-7. February 1990

Dielectric Characterization and Reference Materials;

NIST Tech Note 1338.

April 1990

GEYER, R. G.; WEIL, C. M.; KISSICK, W. A.

Precision Dielectric Measurements Using a Mode-Filtered Cylindrical Cavity Resonator.

Digest, CPEM; June 11-14, 1990; Ottawa, Canada; pp. 174-175. June 1990

HILI, D. A.

Near-Field Detection of Buried Dielectric objects

IEEE Trans. on Geoscience and Remote Sensing, Vol. 27,

No. 4, pp. 364-368

July 1989

Electric and Magnetic Dipole Radiation in a Random Medium.

Electromagnetics; Vol. 10: pp. 279-292. 1990 
HILI, D. A.; KANDA, M.; LARSEN, E. B.; KOEPKE, G. H.; ORR, R. D. Generating Standard Reference Electromagnetic Fields in the NIST Anechoic Chamber, 0.2 to $40 \mathrm{GHz}$ NIST Tech Note 1335 March 1990

JANEZIC, M. D.; GROSVENOR, J. H. Improved Technique for Measuring Permittivity of Thin Dielectrics with a Cylindrical Resonant Cavity

Conf. Record, IEEE Instrumentation \& Measurement Technology Conf., May 14-16, 1991, Atlanta, GA, pp. 580-584 May 1991

JESCH, R. L.

Dielectric Measurements of Five Different Soil Textural Types as Functions of Frequency and Moisture Content NBSIR 78-896 1978

Dielectric Measurements of Oil shale as Functions of Temperature and Frequency

IEEE. Trans. Geosci. and Remote Sensing, Vol. GE-22, No. 2, pp. 99-105

March 1984

Measurement of Shielding Effectiveness of Different Cable and Shielding Configurations by Mode-Stirred Techniques.

IEEE Trans. on EMC; Vol. 30: pp. 222-228. August 1988

JONES, R. N.; BUSSEY, H. E.; LITTLE, W. E.; METZKER, R. F.

Electrical Characteristics of Corn, Wheat, and Soya in the 1-200 MHz Range

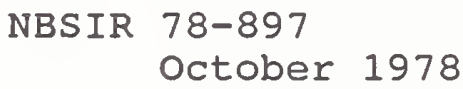

LAWTON, R. A. Autocorrelation and Power Measurement with Pyroelectric and Dielectric Bolometers

IEEE Trans. Instrum. Meas., IM-22, pp. 299-306 December 1973

IAWTON, R. A.; ANDERSON, W. T. Two Layer Dielectric Microstrip Line structure: $\mathrm{SiO}_{2}$ on $\mathrm{Si}$ and GaAs on Si: Modeling and Measurement IEEE Trans. on Microwave Theory and Techniques, Vol. 36 , No. 4 , pp. 785-789

April 1988

WEIL, C. M.; RISSICK, W. A.

The NIST Electromagnetic Properties of Materials Program Conf. Record, IEEE Instrumentation \& Measurement Technology Conf., May 14-16, 1991, Atlanta, GA, pp. 626-630 May 1991 
VANZURA, E. J.; KISSICK, W. A.

Advances in NIST Dielectric Measurement Capability Using a Mode-Filtered Cylindrical Cavity

Proc., 1989 IEEE MTT-S Int. Microwave Symp., 13-15 June 1989, Long Beach, CA, pp. 901-904 1989

VANZURA, E. J.; ROGERS, J. E.

Evaluation of a Resonant Circuit Model Using Reflected S-Parameter Data Conf. Record, IEEE Instrumentation \& Measurement Technology Conf., May 14-16, 1991, Atlanta, GA, pp. 150-155

May 1991 
ADAMS, J. W.

Measurement of Electromagnetic Radiation from Electric Rail Cars

NBSIR 82-1669

August 1982

ADAMS, J. W.; FRIDAY, D. S.

Measurement Procedures for Electromagnetic Compatibility Assessment of Electroexplosive Devices

IEEE Trans. on Electromagn. Compat., Vol. 30, No. 4,

pp. $484-494$

November 1988

ADAMS, J. W.; TAGGART, H. E.

Electromagnetic Compatibility Evaluation of Seven Electronic Brake systems

NBSIR 78-872

February 1978

ADAMS, J. W.; VANZURA, E. J.

Shielding Effectiveness Measurements of Plastics

NBSIR 85-3035

January 1986

EMC Technology and Interference Control News, pp. 39-44 September-October 1986

ADAMS, J. W.; BENSEMA, W. D.; RANDA, M.

Electromagnetic Noise in Grace Mine

NBSIR 74-388

June 1974

ADAMS, J. W.; BENSEMA, W. D.; TOMOEDA, N. C.

Surface Magnetic Field Noise Measurements at Geneva Mine NBSIR 74-369

June 1974

ADAMS, J. W.; CRAWFORD, M. I.; SHAFER, J. F.

Electromagnetic Interference (EMI) Measurements for Automotive Applications

Proc., 1976 SAE Automotive Congress Conf., 23-27 February, 1976, Detroit, MI, pp. 1-6 1976

ADAMS, J. W.; TAGGART, H. E.; SPAULDING, A. D.

Survey Report of the U.S. Bureau of Mines Electromagnetic Noise Measurement Program

NBS Rept. 10723

November 1971

ADAMS, J. W. ; WU, D. I.; BUDLONG, A.

Measurement of Electric Field Strength Near Higher-Powered Personal

Transceivers

NISTIR 90-3938

May 1990

ADAMS, J. W.; RANDA, M.; SHAFER, J. F.; WU, Y.

Near-Field Electric Field Strength Levels of EM Environments Applicable to Automotive Systems

Proc., 1977 IEEE Int. Symp. on Electromagn. Compat.,

2-4 August, 1977, Seattle, WA, pp. 336-343

1977 
ALSPACH, W. J.; MILLER, C. K. S.; REEVE, G. R.

An Assessment of Electromagnetic Interference (EMI) and Electromagnetic Compatibility (EMC) Measurement Practices to Meet U.S. Army Aviation

Research and Development Command EMI/EMC Requirements

$$
\begin{aligned}
& \text { NBSIR } 84-1698(R) \\
& \text { January } 1984
\end{aligned}
$$

ANDREWS, J. R.

Picosecond Pulse Generators Using Microminiature Mercury Switches NBSIR 74-377

1974

Impulse Generator spectrum Amplitude Measurement Techniques

IEEE Trans. Instrum. Meas., Vol. IM-25, No. 4, pp. 380-384 December 1976

ANDREWS, J. R.; ARTHUR, M. G.

Spectrum Amplitude--Definition, Generation and Measurement NBS Tech. Note 699

October 1977

ANDREWS, J. R.; BAIDWIN, E. E.

UHF Impulse Generator NBSIR 78-880

April 1978

SHF Impulse Generator

NBSIR 78-888

June 1978

ARTHUR, M. G.

Impulse spectral Intensity -- What is it?

NBSIR 74-365

May 1974

Proc., 1978 Electromagn. Interference Workshop

NBS SP 551

July 1979

ARTHUR, M. G.; ORR, R. D.; REEVE, G. R.

Planning Guidance for Future EMI Measurement Instrumentation NBSIR 82-1662

April 1982

BAIRD, R. C.

Methods of Calibrating Microwave Hazard Meters

Proc., Int. Symp on Biological Effects and Health Hazards of Microwave Radiation, October, 1973, Warsaw, Poland, pp. 228-236

1973

BELSHER， D. R .

Development of Near-Field Electric Energy Density Meter Model EDM-2 Department of Health, Education, and Welfare, Publ. No. (NIOSH) 75-140

March 1975 
BENSEMA, W. D.

Coal Mine Magnetic-Field Noise Measurements

Proc., $1972 \mathrm{~W}$. Virginia Conf. on Coal Mine Electrotechnology

(1st), 2-4 August, 1972, West Virginia Univ., Morgantown, pp. XII-1 through XII-12 1972

A Noise Spectrum Measurement System Using the Fast Fourier Transform IEEE Trans. Electromagn. Compat., Vol. EMC-19, No.2, pp. 37-43

May 1977

Amplitude, Time, and Frequency Statistics of Quasi-Impulsive Noise Proc., 1977 Electromagn. Compat. Symp., 18-30 June, 1977, Montreux (Switzerland), pp. 347-352 1977

Broadband Orthogonal Array Antenna System: Microprocessor Control and Computation

Record, "EMC '81," 1981 IEEE Int. Symp. on Electromagn. Compat., 18-20 August, 1981, Boulder, CO 1981

Handbook for Broadband Isotropic Antenna System

Volume 1 - Operations Manual

NBSIR 83-1693

July 1983

BENSEMA, W. D.; RANDA, M.; ADAMS, J. W.

Electromagnetic Noise in Robena No. 4 Coal Mine NBS Tech. Note 654

April 1974

Electromagnetic Noise in Itmann Mine NBSIR 74-390

June 1974

BENSEMA, W. D.; ROEPKE, G. H.; MEDLEY, H. W.

Handbook for NBS Multisensor Automated EM Field Measurement System NBSIR 86-3056

October 1986

BENSEMA, W. D.; REEVE, G. R.; KOEPKE, G. H.

A Multisensor Automated EM Field Measurement System Proc., 1985 Instrum. and Meas. Technol. Conf., 20-22 March, 1985, Tampa, FL, pp. 200-202 1985

BOWMAN, R. R.

Field Strength Above $1 \mathrm{GHz}$ : Measurement Procedures for Standard Antennas Proc., IEEE, Special Issue on Radio Meas. Methods and Standards, Vol. 55, No. 6, pp. 981-990 June 1967 
BOWMAN, R. R. (cont.)

Quantifying Hazardous Electromagnetic Microwave Fields: Practical

Considerations

Proc., 1969 Biological Effects and Health Implications of Microwave Radiation, 17-19 September, 1969, Richmond, VA., BRH/DBE 70-2, U.S. Dept. of Health, Education, and Welfare, Rockville, MD. , pp. 204-209

June 1970

Some Recent Developments in the Characterization and Measurement of Hazardous Electromagnetic Fields

Proc., 1973 Int. Symp. Biologic Effects and Health Hazards of Microwave Radiation, 15-18 October, 1973, Warsaw (Poland), pp. $217-227$

1973

A Probe for Measuring Temperature in Radio-Frequency-Heated Material IEEE Trans. Microwave Theory Technol., Vol. MTT-24, No. 1, pp. 43-45 January 1976

Calibration Techniques for Electromagnetic Hazard Meters: $500 \mathrm{MHz}$ To $20 \mathrm{GHz}$ NBSIR 75-805 April 1976

A Temperature Probe for Radio-Frequency Heated Material NBSIR 81-1634 January 1981

CAMELL, D. G.; LARSEN, E. B.; ANSON, W. J .

NBS Calibration Procedures for Horizontal Dipole Antennas

(25 to $100 \mathrm{MHz}$ )

Proc. IEEE Int. Symp. on Electromagn. Compat.,

2-4 August, 1988, Seattle, WA, pp. 390-394 1988

CAVCEY, R. H.

Transmission Loss Through 6061 T-6 Aluminum Using a Pulsed Eddy Current Source

"Materials Evaluation", American Society for Nondestructive Testing, Vol. 47, No. 2, pp. 216-218 February 1989

CAVCEY, R. H.; FRIDAY, D. S.

Aircraft Field Degradation and Electromagnetic Compatibility NBSIR 88-3083

January 1988

CLARR, H. E.

Requirements for an Effective National Nonionizing Radiation Measurement System

NBS SP 613

June 1981 
CRAWFORD, M. L .

Evaluation of Reflectivity Level of Anechoic Chambers Using Isotropic, 3-Dimensional Probing

Proc., 1974 Int. IEEE/AP-S Symp. Dig., 10-12 June, 1974, Atlanta, GA, pp. 28-34 1974

Generation of Standard EM Fields Using TEM Transmission Cells IEEE Trans. Electromagn. Compat., Vol. EMC-16, No. 4, pp. 189-195

November 1974

Generation of Standard EM Fields for Calibration of Power Density Meters $20 \mathrm{kHz}$ to $1000 \mathrm{MHz}$

NBSIR 75-804

January 1975

Techniques for Measurement of Electromagnetic Radiation and Susceptibility of Electronic Equipment

Proc., 1975 Symp. and Technical Exhib. on Electromagn. Compat. (1st), 20-22 May, 1975, Montreux, Switzerland, pp. 38-44

1975

Experimental Evaluation of the Radiation Characteristics of Dipole Sources Enclosed in a TEM Transmission Cell

Proc., 1976 Conf. on Precision Electromagn. Meas., 28 June-1 July, 1976, Boulder, CO, pp. 57-59

1976

Improved Techniques and Instrumentation for EMC Measurements IEEE 1976 Int. Symp. on Electromagn. Compat.,

13-15 July, 1976, Washington, DC 1976

Comparison and Selection of Techniques for Measuring EM Radiated Emissions and Susceptibility of Large Equipment Proc., 1979 Symp. and Technical Exhib. on Electromagn. Compat. (3rd), 1-3 May, 1979, Rotterdam (Netherlands), pp. $115-122$

1979

Evaluation of a Reverberation Chamber Facility for Performing EM Radiated Fields Susceptibility Measurements

NBSIR 81-1638

February 1981

Options to Open-Field and Shielded Enclosure Electromagnetic Compatibility Measurements

Proc., 1981 Int. Electromagn. Compat. Symp.,

10-12 March, 1981, Zurich, Switzerland 1981 
CRAWFORD, M. I. (cont.)

Improving the Repeatability of EM Susceptibility Measurements of Electronic Components When Using TEM Cells

SAE Technical Paper Series, 830607, International Congress and Exposition, 28 February-4 March, 1983, Detroit, MI, pp. 1-8

$$
1983
$$

Evaluation of Shielded Enclosure for EMI/EMC Measurements Without and With RF Anechoic Material

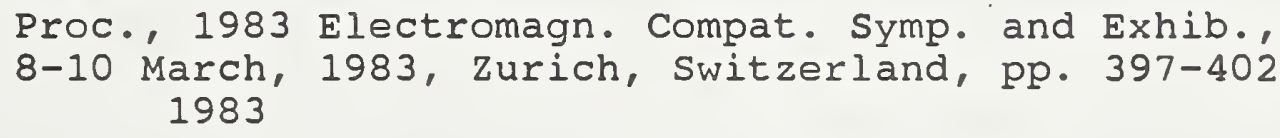

Comparison of Open-Field, Anechoic Chamber and TEM Cell

Facilities/Techniques for Performing Electromagnetic Radiated Emissions Measurements

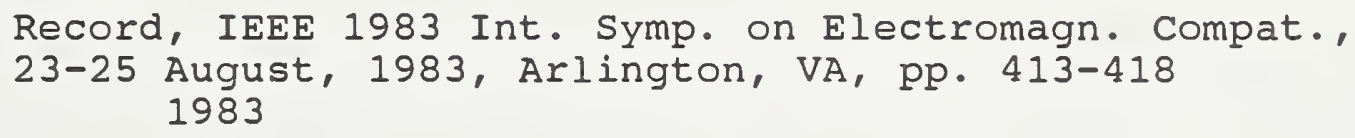

A TEM Driven Reverberating Chamber A Single Facility for Radiated EMS/V Testing $10 \mathrm{kHz}-18 \mathrm{GHz}$ ?

Proc., EMC Expo 1987, Int. Conf. on Electromagn. Compat.,

19-21 May, 1987, San Diego, CA, pp. T11.18- T11.28 1987

TEM/Reverberating Chamber Design/Concept Study: A Single Facility for

Large System Radiated EMC Testing, $10 \mathrm{kHz}-40 \mathrm{GHz}$

PrOC., EMC EXPO, 1-3 August 1989, Washington, DC, pp. B6.22-B6.29 1989

CRAWFORD, M. L.; BEAN, J. L.

NSWC Reverberating Chamber A High Power Microwave Exposure Chamber Proc., 3rd Nat. High Power Microwave Technical Conf., 1-5 December, 1986, Kirtland AFB, NM, p. 5 1986

CRAWFORD, M. L.; KOEPKE, G. H. Performing EM Susceptibility/Vulnerability Measurements Using a Reverberation Chamber Proc., EMC EXPO 1986, Int. Conf. on Electromagn. Compat., 16-19 June, 1986, Washington, DC, pp. T28.7-T28.14 1986

Proc., 7th Int. Zurich Symp. and Technical Exhib. on Electromagn. Compat., 3-5 March, 1987, Zurich, Switzerland, pp. 121-126 1987

Operational Considerations of a Reverberation Chamber for EMC Immunity Measurements, Some Experimental Results Proc., 1984 IEEE Nat. Symp. on Electromagn. Compat., 24-26 April, 1984, San Antonio, TX, pp. 47-54 1984 
CRAWFORD, M. L.; ROEPRE, G. H. (cont.)

Comparing EM Susceptibility Measurement Results Between Reverberation and Anechoic Chambers

Record, IEEE 1985 Int. Symp. on Electromagn. Compat., 20-22 August, 1985, Wakefield, MA, pp. 200-202 1985

Design, Evaluation and Use of a Reverberation Chamber for Performing Electromagnetic Susceptibility/Vulnerability Measurements NBS Tech. Note 1092 April 1986

EMR Test Facilities - Evaluation of Reverberation Chambers Located at NSWC, Dahlgren, VA

NBSIR 86-3051

June 1986

Preliminary Evaluation of Reverberation Chamber Method for Pulsed RF Immunity Testing

Record, IEEE Int. Symp. on Electromagn. Compat.,

16-18 September, 1986, San Diego, CA, pp. 270-278 1986

CRAWFORD, M. L.; LADBURY, J. M. Mode-Stirred Chamber for Measuring Shielding Effectivess of Cables \& Connectors An Assessment of MIL-STD 1344A Method 3008

Proc., 1988 IEEE Int. Symp. on Electromagn. Compat., 1-5 August, 1988, Seattle, WA, pp. 30-36 1988

CRAWFORD, M. L.; THOMAS, C. L. Converting a Rectangular shielded Enclosure into a TEM Transmission Cell for EMI Measurements IEEE 1977 Int. Symp. on Electromagn. Compat., 2-5 August, 1977, Seattle, WA 1977

CRAWFORD, M. L.; WORKMAN, J. L.

Asymmetric Versus Symmetric TEM Cells for EMI Measurements Proc., 1978 IEEE Int. Symp. on Electromagn. Compat., 20-22 June, 1978, Atlanta, GA, pp. 204-210 1978

Using a TEM Cell for EMC Measurements of Electronic Equipment NBS Tech. Note 1013 April 1979

Predicting Free-Space Radiated Emissions from Electronic Equipment Using TEM Cell and Open-Field Site Measurements Record, 1980 Int. Electromagn. Compat. Symp. 1980

Spherical Dipole for Radiating Standard Fields

Dig., 1980 Conf. Precision Electromagn. Meas. June 1980 
CRAWFORD, M. L.; KOEPRE, G. H.; LADBURY, J. M.

EMR Test Facilities Evaluation of Reverberating Chamber Located at RADC, Griffiss, AFB, Rome, New York NBSIR $87-3080$

December 1987

CRAWFORD, M. L.; WORKMAN, J. L.; THOMAS, C. L.

Generation of EM Susceptibility Test Fields Using a Iarge

Absorber-Loaded TEM Cell

IEEE Trans. Instrum. Meas., Vol. IM-26, No. 3, pp. 336-343 September 1977

Expanding the Bandwidth of TEM Cells for EMC Measurements IEEE Trans. Electromagn. Compat., Vol. EMC-20, No. 3, pp. 368-375

August 1978

CRAWFORD, M. L.; LADBURY, J. M.; RIDDLE, B. F.; LARSEN, E. B. Electromagnetic Radiation Test Facilities: Evaluation of a Small

Reverberating Chamber Located at RADC, Griffiss AFB, Rome, NY NISTIR 90-3939

June 1990

CRAWFORD, M. L.; MA, M. T.; LADBURY, J.M.; RIDDLE, B. F.

Measurement \& Evaluation of a TEM/Reverberating Chamber NIST Tech Note 1342

July 1990

CRUZ, J. E.

Design, Construction, and Calibration of the Broadband Electric Field Monitor $(\mathrm{EFM}-5)$

Record, "EMC "81," 1981 IEEE Int. Symp. on Electromagn. Compat., 18-20 August, 1981, Boulder, CO 1981

CRUZ, J. E.; LARSEN, E. B.

Screenroom Measurements of Antenna Factors

Proc., 1985 Instrum. and Meas. Technol. Conf., 20-22 March, 1985, Tampa, FL, p. 208 1985

Assessment of Errors for MIL-STD-461/462

NBS Tech. Note 1300

October 1986

Alternative Techniques for some Typical MIL-STD-461/462 Types of Measurements NBS Tech. Note 1320

March 1989

CRUZ, J. E.; DRIVER, L. D.; KANDA, M.

Design of the National Bureau of Standards Isotropic Magnetic Field Meter (MFM-10) $300 \mathrm{kHz}$ to $100 \mathrm{MHz}$

NBS Tech. Note 1085

October 1985 
DECKER, W. F.; CRAWFORD, M. L.; WILSON, W. A.

Construction of a Large Transverse Electromagnetic Cell NBS Tech. Note 1011

February 1979

DRIVER， L. D.; CRUZ, J. E.

Development of the NBS Isotropic Magnetic-Field Meter (MFM-10), $300 \mathrm{kHz}$ to $100 \mathrm{MHz}$

Proc., 1982 Int. Symp. on Electromagn. Compat.,

8-10 September, 1982, Santa Clara, CA, pp. 460-467 1982

DRIVER, L. D.; RANDA, M.

An Optically Linked Electric and Magnetic Field Sensor for Poynting

Vector Measurements in the Near Fields of Radiating Sources

IEEE Trans. on Electromagn. Compat., Vol. 30,

No. 4, pp. 495-503

November 1988

DRIVER, L. D.; REEVE, G. R.

Application of a Systematic Approach to an Investigation of $\mathrm{HF}$

Interference to a Shipboard Radar set

Proc., 1984 IEEE Nat. Symp. on Electromagn. Compat.,

24-26 April, 1984, San Antonio, TX, pp. 211-218 1984

FITZGERRELL, R. G.

Experimental RF Field Polarization Meter

FAA-RD-74-188

1975

Free-Space Transmission Loss for Anechoic Chamber Performance Evaluation Record, "EMC '81," 1981 IEEE Int. Symp. on Electromagn. Compat., 18-20 August, 1981, Boulder, CO 1981

IEEE Trans. Electromagn. Compat., Vol. EMC-24, No. 3, pp. 356-358 August 1982

A Partial Loop Source of E \& H Fields for Antenna Factor Calibration (A Loop Cell)

Proc., 1982 Antenna Meas. Techniques Assoc., 5-7 October, 1982, New Mexico State University, Las Cruces, NM, pp. 15-1 through $15-22$ 1982

E-Fields Over Ground

Record, IEEE 1983 Int. Symp. on Electromagn. Compat.,

23-25 August, 1983, Arlington, VA, pp. 6-9 1983 
FITZGERRELL, R. G. (cont.)

A Source of E\&H Fields for Antenna-Factor Calibration

IEEE Trans. Electromagn. Compat., Vol. EMC-26,

No. 2, pp. 58-65

May 1984

Site Attenuation

Record, IEEE 1985 Int. Symp. on Electromagn. Compat.,

20-22 August, 1985, Wakefield, MA, pp. 612-617 1985

NBS Tech. Note 1089

November 1985

IEEE Trans. on Electromagn. Compat., Vol. EMC-28,

No. 1 , pp. 38-40

February 1986

Monopole Impedance and Gain Measurements on Finite Ground Planes

IEEE Trans. on Antennas and Propat., Vol. 36,

No. 3, pp. 431-438

March 1988

Monopole Impedance and Gain Measurements of Finite Ground Planes National Institute of Justice Report, 200-87 May 1989

FLANIGAN, W. F. Jr.; BOWMAN, R. R.; LOWELL, W. R .

Nonmetaliic Electrode System for Recording EEG and ECG in

Electromagnetic Fields

Physiology and Behavior, Vol. 18, No. 3, pp. 531-533 1977

FRIDAY, D. S.

Methodology for Statistical Control of the Anechoic Chamber Field

Generation System

NBSIR 85-3033

January 1986

FRIDAY, D. S. ; ADAMS, J. W.

A Statistical Characterization of Electroexplosive Devices (EED)

Relevant to Electromagnetic Compatibility (EMC)

NBS Tech. Note 1094

May 1986

GREENE, F. M.

NBS Field-Strength Standards and Measurements ( $30 \mathrm{MHz}$ to $1000 \mathrm{MHz}$ )

Proc., IEEE Spec. Issue on Radio Measurement Methods and

Standards, Vol. 55, No. 6, pp. 970-981

June 1967

Development and Construction of an Electromagnetic Near-Field

Synthesizer

NBS Tech. Note 652

May 1974 
GREENE, F. M. (cont.)

Development of Electric and Magnetic Near-Field Probes

NBS Tech. Note 658

January 1975

Measurement of RF Power-Absorption in Biological specimens (10 to $100 \mathrm{MHz}$ )

NBS Tech. Note 687

November 1976

HILI, D. A.

Theory of Near-field Phased Arrays for Electromagnetic susceptibility Testing

NBS Tech. Note 1072

February 1984

Electromagnetic Wave Propagation in an Asymmetrical Coal Seam IEEE Trans. on Antennas and Propagat., Vol. AP-34, No. 2, pp. 244-247

February 1986

A Numerical Method for Near-Field Array Synthesis

IEEE Trans. on Electromagn. Compat., Vol. EMC-27, No. 4, pp. 201-211

November 1985

Radio-Wave Propagation from a Forest to a clearing

Electromagnetics, pp. 217-228 1986

Out-of-Band Response of a Coax-to-Waveguide Adapter

IEEE Trans. on Electromagn. Compat., Vol. EMC-28, No. 3, pp. 156-158

August 1986

An Error Bound for Near-Field Array Synthesis

IEEE Trans. on Electromagn. Compat., Vol. EMC-28, No. 4, pp. 273-276

November 1986

Effect of a Thin Conducting sheet on the Fields of a Buried Magnetic Dipole

Electromagnetics, pp. 71-79 1987

A Circular Array for Plane-Wave Synthesis

IEEE Trans. on Electromagn. Compat., Vol. 30, No. 1, pp. 3-8 February 1988

Electromagnetic Scattering by Buried objects of Low Contrast IEEE Trans. on Geoscience and Remote Sensing, Vol. 26, No. 2 , pp. 195-203 March 1988

Electromagnetic Detection of Long Conductors in Tunnels Proc., Third Tunnel Detection Symp., 12-15 January 1988, Golden, CO, pp.518-537 1988 
HILL, D. A. (cont.)

Reflection Coefficient of a Waveguide with Slightly Uneven Walls IEEE Trans., Microwave Theory and Techniques, Vol 37,

No. 1 , pp. 244-252 January 1989

Clutter Models for Subsurface Electromagnetic Applications NISTIR 89-3909

February 1989

Quasi-static Analysis of a Two-Wire Transmission Line Located at an Interface

Radio science, Vol. 25, No. 4, pp. 435-440 July-August 1990

Near-Field and Far-Field Excitation of a Long Conductor in a Lossy Medium

$$
\begin{aligned}
& \text { NISTIR } 3954 \\
& \text { September } 1990
\end{aligned}
$$

A Generalization of the Cornu Spiral for Lossy Media

Journal of Applied Physics, Vol. 69, No. 3, pp. 1772-1774 February 1991

HIL乙, D. A.; ROEPRE, G. H.

A Near-field Array of Yagi-Uda Antennas for Electromagnetic

Susceptibility Testing

NBS Tech. Note 1082

July 1985

IEEE Trans. on Electromagn. Compat., Vol. EMC-28, No. 4, pp. 273-276

November 1986

An Array of Dipoles for Plane Wave Synthesis

Proc., 1985 Int. Symp. on Antennas and Propagat.,

20-22 August, 1985, Kyoto, Japan, pp. 177-180 1985

HILL, D. A. ; WAIT, J.R.

Propagation Along a Coaxial Cable with a Helical shield

IEEE Trans. Microwave Theory Technol., Vol. MTT-28, No. 2,

pp. 84-89

$$
\text { February } 1980
$$

Electromagnetic Characteristics of a coaxial Cable with Periodic slots

IEEE Trans. Electromagn. Compat., Vol. EMC-22,

No. 4, pp. 303-307

November 1980

Anomalous Vertical Magnetic Field for Electromagnetic Induction in a Laterally Varying Thin Conductive Sheet

Radio science, Vol. 21, No. 4, pp. 617-621

July-August 1986 
HUDSON, P. A.; MELQUIST, D. G.; ONDREJKA, A. R.; WERNER, P. E.

A Program to Evaluate/Improve Instrumentation and Test Methods for

Electroexplosive Device Safety Qualification

NBSIR 73-323

June 1973

Completion of the Program to Evaluate/Improve Instrumentation and Test Methods for Electroexplosive Device Safety Qualification

NBSIR 74-379

June 1974

JESCH, R. L.

Susceptibility of Emergency Vehicle Sirens to External Radiated

Electromagnetic Fields

National Institute of Justice Technology Program, NIJ

Report-200-85

May 1986

A Survey of Triaxial and Mode-Stirred Techniques for Measuring the

Shielding Effectiveness of Connectors and Cables NBSIR 86-3060

October 1986

Measurement of Shielding Effectiveness of Different Cable and Shielding Configurations by Mode-stirred Techniques

NBSIR 87-3076

October 1987

Measurement of Shielding Effectiveness of Different Cable and Shielding Configurations by Mode-Stirred Techniques

IEEE Trans. on EMC, Vol. 30, pp. 222-228

August 1988

RANDA, M.

Time and Amplitude Statistics for Electromagnetic Noise in Mines

NBSIR $74-378$

July 1974

The Characteristics of a Relatively Short Broadband Linear Antenna with Tapered Resistive Loading

Proc., Int. Symp. on Antennas and Propagat. Soc.,

20-22 June, 1977

1977

IEEE Antennas and Propagat. Soc. Dig., 20-22 June, 1977,

pp. 230-233

1977

A Relatively Short Cylindrical Broadband Antenna with Tapered Resistive Loading for Picosecond Pulse Measurements

NBSIR 77-861

August 1977 
RANDA, M. (cont.)

A Relatively Short Cylindrical Broadband Antenna with Tapered Resistive Loading for Picosecond Pulse Measurements

IEEE Trans. Antennas Propagat., Vol. AP-26,

No. 3, pp. $439-447$ 1977

A Broadband Antenna with Tapered Resistive Loading for EMI Measurements Proc., 1977 IEEE Int. Symp. on Electromagn. Compat., 2-4 August, 1977, Seattle, WA, pp. 13-18 1977

The Characteristics of Broadband, Isotropic Electrical Field and Magnetic Field Probes

NBSIR 77-868

November 1977

Transients in Resistively Loaded Antennas and Their Comparison with Conical Antennas and TEM Horns

NBSIR $78-876$

March 1978

Analytical and Numerical Techniques for Analyzing an Electrically Short Dipole with a Nonlinear Load

NBSIR 78-898

November 1978

IEEE Antennas and Propagat., Vol. AP-28, No. 1, pp. 71-78 January 1980

The Characteristics of a Traveling-Wave, Linear Antenna with a Nonlinear Load

Dig. Abstract, 1979 IEEE AP symp.

January 1979

The Time Domain Characteristics of a Traveling Wave Linear Antenna with

Linear and Non-Linear Loads

NBSIR 78-892(R)

February 1979

The Effects of Resistive Loading on TEM Horns

NBSIR 79-1601

August 1979

IEEE Antennas and Propagat., Vol. AP-28, No. 1, pp. 71-78 January 1980

IEEE Trans. Electromagn. Compat., Vol. EMC-24,

No. 2 , pp. 245-255

May 1982

Transients in Resistively Loaded Antennas and Their Comparison with Conical Antennas and a TEM Horn

IEEE Trans. Antennas Propagat., Vol. AP-28,

No. 1, pp. 132-136

January 1980 
RANDA, M. (cont.)

The Time-Domain Characteristics of a Traveling-Wave Linear Antenna with Linear and Nonlinear Parallel Loads

IEEE Trans. Antennas Propagat., Vol. AP-28, No. 2 March 1980

The Characteristics of a Linear Antenna with Tapered Resistive and Capacitive Loading

Proc., IEEE AP Symp., 2-6 June, 1980, Quebec, Canada, Vol. 2, AP.18-2, pp. 696-699 1980

Theoretical and Experimental Investigations of Loading Effects Due to a Perfectly Conducting Rectangular Cylinder in a Transverse

Electromagnetic Cell

4th Symp. and Tech. Exhib. on Electromagn. Compat., March, 1981, Zurich, Switzerland 1981

Theoretical and Experimental Investigations of Electromagnetic Field Distortion Due to a Perfectly Conducting Rectangular Cylinder in a Transverse Electromagnetic Cell

NBS Tech. Note 1028

April 1981

An Electric and Magnetic Field Sensor for Simultaneous Electromagnetic Near-Field Measurements - Theory

NBS Tech. Note 1062

April 1983

An Electromagnetic Near-field Sensor for Simultaneous Electric and Magnetic-Field Measurements

IEEE Trans. Electromagn. Compat., Vol. EMC-26,

No. 3, pp. 102-110

August 1984

Transients in a Resistively Loaded Loop Antenna

Proc., 1984 Int. Symp. on Electromagn. Compat.,

16-18 October, 1984, Tokyo, Japan, Vol. 1, pp. 286-290 1984

A Methodology for Evaluating Microwave Anechoic Chamber Measurements Proc., 1985 Symp. and Technical Exhib. on Electromagn. Compat., 5-7 March, 1985, Zurich, Switzerland, pp. 69-74 1985

A Microstrip Patch Antenna as a Standard Transmitting and Receiving Antenna.

Digest, 1989 Int'l Symp. on EMC, 8-10 September, 1989, Nagoya,

Japan, pp. 460-462 1989

IEEE Trans. on Electromagnetic Compatibility, Vol. 32, No. 1 ; pp. 5-8.

February 1990 
RANDA, M.; ADAMS, J. W.

Amplitude Statistics of Electromagnetic Noise in Coal Mines

Proc., 1973 Thru-the-Earth Electromagn. Workshop,

15-17 August, 1973, Colorado School of Mines,

Golden, CO, pp. 156-160 1973

URSI Dig., IEEE Trans. Antennas Propagat. May 1975

RANDA, M.; DRIVER, L. D.

An Isotropic, Electric-Field Probe with Tapered Resistive Dipoles for Broadband Use, $100 \mathrm{kHz}-18 \mathrm{GHz}$

Record, 1986 IEEE Int. Symp. on Electromagn. Compat.,

16-18 September, 1986, San Diego, CA, pp. 256-261 1986

IEEE Trans. on Microwave Theory and Techn., Vol. MTT-35,

No. 2, pp. 124-130

February 1987

A Broadband, Electric-Field Probe Using Resistively Tapered Dipoles, 100 $\mathrm{kHz}-18 \mathrm{GHz}$

Proc., 1986 IEEE/MTT/S Int. Microwave Symp. Dig.,

2-4 June, 1986, Baltimore, MD, pp. 621-624 1986

An Optically Linked Electric and Magnetic Field Sensor for Poynting

Vector Measurements in the Near Field of Radiating sources CPEM Dig., 7-10 June, 1988, Tsukuba Science City, Japan, pp. $32-33$

1988

RANDA, M.; MAY, W. G.

A Millimeter Wave Isolator Containing a Semiconductor Rod in a Circular Waveguide

IEEE Trans. Instrum. Meas., No. IM-24, No. 3, pp. 264-266 September 1975

RANDA, M.; NAHMAN, N. S.

Standards for Measurement of Electromagnetic Fields Proc., 1985 Instrum. and Meas. Technol. Conf., 20-22 March, 1985, Tampa, FL, pp. 20-23 1985

RANDA, M.; ORR, R. D.

A Radio-frequency Power Delivery System: Procedures for Error Analysis and Self-Calibration

NBS Tech. Note 1083

August 1985

Near-Field Gain of a Horn and an Open-Ended Waveguide: Comparison

Between Theory and Experiment

Proc., 5th Int. Conf. on Electromagn. Compat.,

29 September-2 October, 1986, University of York, England, pp. 137-145

1986 
RANDA, M.; ORR, R. D. (cont.)

Generation of Standard Electromagnetic Fields in a TEM Cell NBS Tech. Note 1319

August 1988

KANDA, M.; RANDA, J. P.

Estimation of Electromagnetic Firlds in Complex Envixonments

Proc., 9th Int'l Symp. \& Tech. Exhibition, EMC, March 12-14, 1991,

Zurich, Switzerland, pp. 337-342 1991

RANDA, M.; RIES, F. X.

Time Domain Sensors for Radiated Impulsive Measurements

Proc., IEEE 1982 Int. Symp. on Electromagn. Compat.,

8-10 September, 1982, Santa Clara, CA, pp. 296-301 1982

IEEE Trans. Antennas Propagat., Vol. AP-31, No. 3, pp. 438-444

May 1983

RANDA, M.; WYSS, J. C.

Evaluation of off-Axis Measurements Performed in an Anechoic Chamber NBS Tech. Note 1305

October 1986

KANDA, M.; ADAMS, J. W.; BENSEMA, W. D. Electromagnetic Noise in McElroy Mine

NBSIR 74-389

June 1974

RANDA, M.; RANDA, J. P.; NAHMAN, N. S .

Possible Estimation Methodologies for Electromagnetic Field Distributions in Complex Environments

NBS Tech. Note 1081

March 1985

KANDA, M.; RIES, F. X.; BELSHER, D. R .

A Broadband Isotropic, Real-Time, Electric Field Sensor (BIRES) Using

Resistively Loaded Dipoles

NBSIR 79-1622

December 1979

KANDA, M.; RIES, F. X.; DRIVER, L. D.; ORR, R. D.

Design Considerations for Broadband Magnetic-Field Sensors

Dig., 1982 Conf. on Precision Electromagn. Meas.,

28 June-1 July, 1982, Boulder, CO, pp. P-11 - P-13

1982

An Electric and Magnetic Field Sensor Concept for Simultaneous

Near-Field Electromagnetic Components when Using TEM Cells

Proc., 1983 Electromagn. Compat. Symp. and Exhib.,

8-10 March, 1983, Zurich, Switzerland, pp. 263-266 1983 
KANDA, M.; LARSEN, E. B.; BORSERO, M.; GALLIANO, P. G.; YODOSHIMA, I.;

NAHIMAN, N. S.

Standards for Electromagnetic Fields Measurements

Special Issue of Proc., IEEE on Radio Meas. and Standards,

Vol. 94, No. 1, pp. 120-128

January 1986

ROEPRE, G. H.; MA, M. T.

A New Method for Determining the Emission Characteristics of an Unknown

Interference source

Proc., IEEE 1982 Int. Symp. on Electromagn. Compat.,

8-10 September, 1982, Santa Clara, CA, pp. 151-156 1982

Proc., 1983 Electromagn. Compat. Symp. and Exhib., 8-10 March, 1983, Zurich, Switzerland, pp. 263-266 1983

ROEPRE, G. H.; MA, M. T.; BENSEMA, W. D.

Theory and Measurements of Radiated Emissions Using a TEM Cell

NIST Tech Note 1326

January 1989

Implementation of an Automated System for Measuring Radiated Emissions Using a TEM cell

IEEE Trans. on Instrum. and Meas., Vol. 38,

No. 2 , pp. 473-479

April 1989

RUFFEL, J.; MALEWSKI, R.; VAN HEESWIJK, R.; LAWTON, R. A.

Dynamic Performance of Digital Recorders Used for Monitoring

High-Voltage Impulse Tests

Proc., IEEE Instrum. and Meas. Technol. Conf.,

25-27 March, 1986, Boulder, CO, Vol. IM-35,

No. 4 , pp. 591-595 1986

LARSEN, E. B.

Calibration of Radio Receivers to Measure Broadband Interference NBSIR 73-335

September 1973

Background and Present status of RF Probe Development at NBS Record, "EMC '81," 1981 IEEE Int. Symp. on Electromagn. Compat., 18-20 August, 1981, Boulder, CO 1981

Calibration and Meaning of Antenna Factor and Gain for EMI Antennas Interference Technology Engineers' Master (ITEM 1986), pp. $113-335$

1986

LARSEN, E. B.; ANDREWS, J. R.

Using Fiber Optics in A Broadband, Sensitive, Isotropic Antenna $15 \mathrm{KHz}$ to $150 \mathrm{MHz}$

Proc., 1976 IEEE Int. Symp. on Electromagn. Compat.,

13-15 July, 1976, Washington, DC 1976 
LARSEN, E. B.; CRUZ, J. E.

E\&H Fields in Transmission Lines and Coils for susceptibility Testing, Probe Calibration, and RF Exposure Chambers

Proc., 1985 Instrum. and Meas. Technol. Conf.,

20-22 March, 1985, Tampa, FL, p. 199 1985

LARSEN, E. B.; RIES, F. X.

Design and Calibration of the NBS Isotropic Electric-Field Monitor

$(E F M-5), 0.2$ to $1000 \mathrm{MHz}$

NBS Tech. Note 1033

March 1981

LARSEN, E. B.; SHAFER, J. F.

Surveys of Electromagnetic Field Intensities Near Representative

Higher-Power FAA Transmitting Antennas

FAA-RD -77

December 1977

LARSEN, E. B.; ANDREWS, J. R.; BALDWIN, E. E.

Sensitive Isotropic Antenna with Fiber-Optic Link to a Conventional

Receiver

NBSIR 75-819

September 1976

LARSEN, E. B.; EHRET, R. L.; CAMELL, D. G.; KOEPKE, G. H.

Calibration of Antenna Factor at a Ground Screen Field Site Using an

Automatic Network Analyzer

Proc., IEEE 1989 Nat. Symp. on Electromagn. Compat.,

23-25 May 1989, Denver, CO, pp. 19-24

1989

LAWTON, R. A.

A New Standard for Electric Field Strength

IEEE Trans. Instrum. Meas., Vol. IM-19, pp. 45-51 February 1970

LAWTON, R. A.; ONDREJKA, A. R. Antennas and the Associated Time Domain Range for the Measurement of Impulsive Fields

NBS Tech. Note 1008

November 1978

LIU, B. H.; CHANG, D. C.; MA, M. T.

Eigenmodes and the Composite Quality Factor of a Reverberating Chamber NBS Tech. Note 1066

August 1983

Design Consideration of Reverberating Chambers for Electromagnetic Interference Measurements

Record, IEEE 1983 Int. Symp. on Electromagn. Compat.,

23-25 August, 1983, Arlington, VA, pp. 508-512 1983

MA, M. T.

A Theoretical Study of Unbalanced Ground Effects on Receiving Dipoles NBSIR 79-1605

May 1979 
MA, M. T. (cont.)

Arrays of Discrete Elements

Antenna Engineering Handbook, Chapter 3, R. C. Johnson and H.

Jasik, McGraw-Hill Book Co.

January 1984

Error Analysis of Radiation Characteristics of an Unknown Interference

Source Based on Power Measurements

Proc., 1984 Int. Symp. on Electromagn. Compat.,

16-18 October, 1984, Tokyo, Japan, pp. 39-44

1984

Measurements of Unintentional Electromagnetic Emissions

Proc., IEEE Spec. Issue on Radio Meas. Methods and Standards, Vol. 74, No. 1, pp. 110-111

January 1986

Measuring Electromagnetic Interference, Part II; Reverberating Chambers Test and Measurement World, pp. 74-90 May 1986

Shielding Effectiveness Measuring Using an Apertured TEM Cell in a Reverberation Chamber

IEEE Int. Symp. on Electromagn. Compat., August 1986,

San Diego, CA 1986

Characterization of Unknown RF Leakage Sources: Problems, Solutions and Practical Implications

URSI XXIInd General Assembly, 24 August - 2 September, 1987,

Tel Aviv, Israel 1987

Understanding Reverberating Chambers as an Alternative Facility for EMC Testing

J. of Electromagn. Waves and Appl., Vol. 2, pp. 339-351

March \April 1988

Theory and Measurements of Unintentional Radiators

CPEM Dig., 7-10 June, 1988, Tsukuba Science City, Japan,

pp. $30-31$ 1988

How High is the Level of Electromagnetic Fields Radiated by an ESD?

Proc., 8th Int'1. Symp. \& Tech. Exhibition on EMC,

7-9 March 1989, Zurich, Switzerland, pp. 361-365 1989

MA, M. T.; ARTHUR, M. G.

A Study of Distribution of Electromagnetic Fields Inside Buildings with Apertures Excited by an External Source

NBSIR 82-1659

February 1982 
MA, M. T.; BENSEMA, W. D.

Automated TEM Cell for Measuring Unintentional EM Emissions

Proc., EMC Expo 1987, Int. Conf. on Electromagn. Compat.,

19-21 May, 1987, San Diego, CA, pp. T11.1. - T11.12 1987

MA, M. T.; CRAWFORD, M. L.

Facilities for Improving Evaluations of Electromagnetic Susceptibilities of Weapon systems and Electronic Equipment

NISTIR 89-3928

November 1989

MA, M. T.; FITZGERRELI, R. G.

Design of a Van-Top Low-Profile HF Antenna OTR-77-131

October 1977

MA, M. T.; RANDA, M.

Electromagnetic Compatibility and Interference Metrology

NBS Tech. Note 1099

July 1986

MA, M. T.; KOEPKE, G. H.

A Method to Quantify Radiation Characteristics of an Unknown

Interference Source

NBS Tech. Note 1059

October 1982

Uncertainties in Extracting Radiation Parameters for an Unknown

Interference Source Based on Power and Phase Measurements

NBS Tech. Note 1064

June 1983

MA, M. T.; WILSON, P. F.; CHANG, D. C.

Excitation of a TEM Cell by a Vertical Electric Hertzian Dipole NBS Tech. Note 1037

March 1981

MA, M. T.; CHANG, D. C.; SREENIVASIAH, I.

A Method of Determining the Emission and Susceptibility Levels of Electrically Small Objects Using a TEM Cell

NBS Tech. Note 1040

April 1981

MA, M. T.; KANDA, M.; CRAWFORD, M. L.; LARSEN, E. B.

A Review of Electromagnetic Compatibility/Interference Measurement Methodologies

Proc., IEEE, Vol. 73, No. 3, pp. 388-411

March 1985

MARTZLOFF, F. D.; WILSON, P. F.

Fast Transient Tests - Trivial or Terminal pursuit?

Proc., 7th Int. Zurich Symp. and Technical Exhib. on Electromagn. Compat., 3-5 March, 1987, Zurich, Switzerland, pp. 283-288 1987 
MASTERSON, R. D.

A Photonic Electric Field Probe for Frequencies up to $2 \mathrm{GHz}$

Proc., Soc. for Photo-Optical Instrumentation Engineers (SPIE), Vol. 720 , p. 100 1986

MASTERSON, R. D.; DRIVER, L. D.

A Broadband, Isotropic, Photonic Electric Field Probe for Measurements from $10 \mathrm{kHz}$ to Above $1 \mathrm{GHz}$

Proc., High Bandwith Analog Applications of Photonics II, SPIE Int. Soc. of Optical Engineers, Vol. 987,

8 -9 September, 1988, Boston, MA, pp. 107-118 1989

MASTERSON, K. D.; DRIVER, L. D. ; KANDA, M.

Photonic Probes for the Measurement of Electromagnetic Fields Over Broad Bandwidths

Proc., IEEE 1989 Nat. Symp. on Electromagn. Compat.,

23-25 May 1989, Denver, CO, pp. 1-6 1989

MILLER, C. R. S .

EMI - A Problem of Growing Concern

Report of the 63rd Nat. Conf. on Weights and Measures NBS SP 532

1978

Challenges of EMI Measurements

Proc., Nat. Conf. of Standards Laboratories,

22-25 September, 1980, pp. 8-1 - 8-17

1980

The EMI Measurement Challenge

Proc., 1983 Meas. Sci. Conf., 20-21 January, 1983,

Palo Alto, CA, pp. 189-197

1983

NABMAN, N. S.

Miniature Superconductive Coaxial Transmission Lines

Proc., IEEE, Vol. 61, pp. 76-79

January 1073

NABMAN, N. S.; KANDA, M.; LARSEN, E. B.; CRAWFORD, M. L.

Methodology for Standard Electromagnetic Field Measurements

IEEE Trans. Instrum. Meas., Vol. IM-34, No. 4, pp. 490-503 December 1985

NEWELL, A. C.; CRAWFORD, M. L.

Planar Near-Field Measurements on High Performance Array Antennas NBSIR 74-380

July 1974

ONDREJKA, A. R.; ADAMS, J. W.

Shielding Effectiveness (SE) Measurement Techniques

Proc., 1984 IEEE Nat. Symp. on Electromagn. Compat.,

24-26 April, 1984, San Antonio, TX, pp. 249-256 1984 
ONDREJKA, A. R.; ADAMS, J. W. (cont.)

Shielding Effectiveness (SE) Measurement Techniques

Proc., 1984 EMI/RFI Technical Conf., The Soc. of Plastics

Engineers, Inc., 18-20 June, 1984, Chicago, IL, pp. 19-26 1984

RANDA, J P.

Theoretical Considerations for a Thermo-Optic Microwave Electric-Field Probe

Journal of Microwave Power and Electromagnetic Energy, Vol. 25, No. 3, pp. 133-140 1990

RANDA, J. P.; KANDA, M.

Multiple-Source, Multiple-Frequency Error of an Electric Field Meter

IEEE Trans. Antennas Propagat., Vol. AP-33, No. 1, pp. 2-9 January 1985

A Directional Scanning Technique for Characterization of Complex Electromagnetic Environments

Dig., 1985 IEEE/APS Symp. on Antennas and Propagat.,

17-21 June, 1985, University of British Columbia,

Vancouver, B. C., Canada, pp. 521-524 1985

Directional Scanning of Complex Electromagnetic Environments Proc., 1985 Int. Symp. on Antennas and Propagat.,

20-22 August, 1985, Kyoto, Japan, pp. 899-902 1985

A Finite-element Action Approach to the Characterization of Complex Electromagnetic Environments

Proc., 1985 Int. Symp. on Antennas and EM Theory,

26-28 August, 1985, Beijing, China, pp. 48-53 1985

High Frequency Errors of an Electric-field-meter in Complicated Environments

Record, IEEE 1985 Int. Symp. on Electromagn. Compat.,

20-22 August, 1985, Wakefield, MA, pp. 618-621 1985

A Lattice Approach to Complex Electromagnetic Environments Proc., 1986 IEEE Int. Symp. on Electromagn. Compat., September, 1986, San Diego, CA, pp. 329-331 1986

A Lattice Approach to Volumes Irradiated by Unknown Sources

NBS Tech. Note 1303

October 1986

A Lattice Approach to Environments Irradiated by Unknown Sources Proc., 7th Int. Electromagn. Compat. Symp., March 1987, Zurich, Switzerland, pp. 191-195

1987 
RANDA, J. P.; RANDA, M. (cont.)

A New Approach to Volumes Irradiated by Unknown Sources IEEE Trans. on Electromagn. Compat., pp. 273-281 November 1987

RANDA, J. P.; KANDA, M.; MELQUIST, D. G.

Possible Designs for Electric-Field Strength-Probes for Millimeter Waves NBSIR 88-3084

February 1988

RANDA, J. P.; RANDA, M.; MELQUIST, D. G.; ORR, R. D.

Thermo-optic Designs for Microwave and Millimeter-wave Electric-Field Probes

Proc., IEEE Symp. on Electromagn. Compt., 23-25 May 1989,

Denver, CO, pp. 7-11 1989

RANDA, J. P.; RANDA, M.; MELQUIST, D. G ; SEGA, R. M.; NORGARD, J. D.

High Frequency Electric Field Probe Development

Proc., EMC EXPO'88, Int. Conf. on Electromagn. Compat.,

10-12 May, 1988, Washington, DC, pp. T15.31-T15.37

1988

REEVE, G. R.

Calibration of Impulse Noise Generators

NBSIR 73-343

October 1973

A Standard Percent Modulation Measurement system

Dig. 1976 CPEM Conf., pp. 165-166

June 1976

Synthesized Isotropic Pattern Antennas for EM Field Measurements

Record, "EMC' $81, " 1981$ IEEE Int. Symp. on Electromagn. Compat.,

18-20 August, 1981, Boulder, CO 1981

Alternate EMI Measurement Techniques for Microelectronic Circuits

Proc., EMC EXPO 1986, Int. Conf. on Electromagn. Compat., 16-19

June, 1986, Washington, DC, pp. T26.1-T26.4 1986

Proficiency Testing for MIL-STD 462 NVLAP Laboratories

Dig., EMC EXPO'88, 10-12 MaY, 1988, Washington, DC,

T33.13 - T33.15

September 1988

Proficiency Testing for MIL-STD 462 NVLAP Laboratories. Dig., EMC EXPO

'88; 10-12 May, 1988; Washington, DC; T33.13 - T33.15.

September 1988

REEVE, G. R.; WAINWRIGHT, A. E.

A Frequency Tracking, Tuned, Receiving Monopole

Record, IEEE/APS Symp., June, 1981 1981 
RIES, F. X.; MILIER, C. K. S.

Influence of Electromagnetic Interference on Electronic Devices Bulletin OIML Seminar

December 1981

SCOTT, W. W., Jr.; ADAMS, J. W.; BENSEMA, W. D.; DOBROSKI, H.

Electromagnetic Noise in Lucky Friday Mine

NBSIR 74-391

October 1974

SHAFER, J. F.

Field Strength Levels in Vehicles Resulting from Communications

Transmitters

National Institute of Justice Report, 200-83 June 1984

SIMPSON, P. A.

Broadband Pulsed/CW Calibration Signal Standard for Field Intensity

Meter (FIM) Receivers

NBSIR 74-371

June 1974

SREENIVASIAH, I.; CHANG, D. C.

Variational Expression for the Scattering Matrix of a Coaxial Line step

Discontinuity and its Application to an Over Moded Coaxial TEM Cell NBSIR 79-1606

May 1979

SREENIVASIAH, I.; CHANG, D. C.; MA, M. T.

Characterization of Electrically Small Radiating sources by Tests Inside

a Transmission Line Cell

NBS Tech. Note 1017

March 1980

A Critical study of Emission and Susceptibility Levels of Electrically

Small Objects from Tests Inside a TEM Cell

Record, "EMC '81," 1981 IEEE Int. Symp. on Electromagn. Compat., 18-20 August, 1981, Boulder, CO

1981

Emission Characteristics of Electrically Small Radiating Sources from

Tests Inside a TEM Cell

IEEE Trans. Electromagn. Compat., Vol. EMC-23, No. 3, pp. 113-121

August 1981

STUBENRAUCH, C. F.; SPIESS, W.; GALLIANO, P. G.; BABJI, T.

International Intercomparison of Electric Field strength at $100 \mathrm{MHz}$

IEEE Trans. Instrum. Meas., Vol. IM-32, No. 1, pp. 235-237 March 1983

TAGGART, H. E.

Methods of Suppressing Automotive Interference

NBS SP $480-44$

November 1981 
TAGGART, H. E. (cont.)

Radiated EMI Instrumentation Errors

EMC Technology Magazine, Vol. 1, No. 4, pp. 26-35 October 1982

TIPPET, J. C.; CHANG, D. C.

Radiation Characteristics of Dipole Sources Located Inside a

Rectangular, Coaxial Transmission Line

NBSIR 75-829

January 1976

A New Approximation for the Capacitance of a Rectangular, Coaxial, Strip Transmission Line

IEEE Trans. Microwave Theory Technol., pp. 602-604

September 1976

Higher Order Modes in Rectangular Coaxial Line with Infinitely Thin

Inner Conductor

NBSIR 78-873

March 1978

Characteristic Impedance of a Rectangular Coaxial Line with offset Inner Conductor

IEEE Trans. Microwave Theory Technol., Vol. MTT-26, No. 11,

pp. $876-883$

November 1978

Dispersion and Attenuation Characteristics of Modes in a TEM Cell with a Lossy Dielectric Slab

NBSIR 79-1615

July 1979

TIPPET, J. C.; CHANG, D. C.; CRAWFORD, M. L.

An Analytical and Experimental Determination of the Cutoff Frequencies of Higher-Order TE Modes in a TEM Cell

NBSIR 76-841

June 1976

VANZURA, E. J.

Automated System for Electromagnetic Field Generation and Immunity Testing

Proc., 1988 IEEE Instrum./Meas. Technol. Conf., 19-22 April, 1988, San Diego, CA, pp. 3-10
1988

VANZURA, E. J.; ADAMS, J. W.

Generating Constant Electromagnetic Fields Inside a Partially-Loaded

Shielded Room

Test and Meas. World, pp. 72-83

November 1987

WACKER, P. F .

Quantifying Hazardous Microwave Fields: Analysis

Proc., 1969 Symp. on Biological Effects and Health Implications of Microwave Radiation, 17-19 September, 1969, U.S. Department of Health Education, and Welfare, Rockville, MD. Richmond, VA, BRH/DBE 70-2, pp. 197-203

June 1970 
WACKER, P. F.; BOWMAN, R. R .

Quantifying Hazardous Electromagnetic Fields: Scientific Basis and Practical Considerations

IEEE Trans. Microwave Theory Technol., Vol. MTT-19, No. 22 February 1971

WILSON, P. F.

A Comparison Between Near-Field Shielding Effectiveness Measurements

Based on Coaxial Dipoles and on Electrically Small Apertures

IEEE Trans. on Electromagn. Compat., Vol. 30, No. 1, pp. 23-28

$$
\text { February } 1988
$$

WILSON, P. F.; CHANG, D. C.

Mode Coupling by a Longitudinal slot for a Class of Planar Waveguiding Structures: Part I - Theory

IEEE Trans. on Microwave Theory and Techniques, Vol. MTT-33, No. 10, pp. 981-987 October 1985

Mode Coupling by a Longitudinal slot for a Class of Planar Waveguiding Structures: Part II - Applications IEEE Trans. on Microwave Theory and Techniques, Vol. MTT-33, No. 10, pp. 988-993 October 1985

WILSON, P. F.; MA, M. T.

Small Aperture Analysis of the Dual TEM Cell Proc., 1984 IEEE Nat. Symp. on Electromagn. Compat., 24-26 April, 1984, San Antonio, TX, pp. 365-369 1984

Some Problems Associated with Interpreting Shielding Effectiveness Measurement Results

Proc., 1984 EMI/RFI Technical Conf., The Soc. of Plastics Eng., Inc., 18-20 June, 1984, Chicago, IL, pp. 9-18 1984

Small Aperture Analysis of the Dual TEM Cell and an Investigation of Test Object Scattering in a single TEM Cell

NBS Tech. Note 1076

October 1984

Small obstacle Loading in a TEM Cell

Proc., 1984 Int. Symp. on Electromagn. Compat.,

16-18 October, 1984, Tokyo, Japan, pp. 30-35 1984

Input Impedance of a Probe Antenna in a TEM Cell

IEEE Trans. Electromagn. Compat., Vol. EMC-26, No. 4, pp. 154-161

November 1984

Factors Influencing Material Shielding Effectiveness Measurements Record, IEEE 1985 Int. Symp. on Electromagn. Compat., 20-22 August, 1985, Wakefield, MA, pp. 29-33 1985 
WILSON, P. F.; MA, M. T. (cont.)

Shielding Effectiveness Measurements in a Dual TEM Cell

IEEE Trans. Electromagn. Compat., Vol. EMC-27, No. 3, pp. 137-142

August 1985

Measurements of Electromagnetic Shielding Capability of Materials Proc., IEEE Regional Conf. and Exhib. on Electromagn. Compat., January 1986, Vol. 74, No. 1, pp. 112-115 1986

Electromagnetic Shielding Effectiveness: Measurement Techniques and Interpretations

1986 IEEE Regional Conf. and Exhib. on Electromagn. Compat., 6 February, 1986, Anaheim, CA, pp. 1-14 1986

A Study of Techniques for Measuring the Electromagnetic shielding Effectiveness of Materials

NBS Tech. Note 1095

May 1986

Methods for Measuring the Near-Field and Far-Field Shielding

Effectiveness of Materials

Proc., EMC Expo 1986 Int. Conf. on Electromagn. Compat.,

16-19 June, 1986, Washington, DC, pp. \#T28.1-T28.6 1986

Simple Approximate Expressions for Higher-Order Mode Cut off and Resonant Frequencies in TEM Cells IEEE Trans. on Electromagn. Compat., Vol. EMC-28, No. 3, pp. $125-130$

August 1986

Shielding Effectiveness Measurements Using an Apertured TEM Cell in a Reverberation Chamber

Record, 1986 IEEE Int. Symp. on Electromagn. Compat., 16-18 September, 1986, San Diego, CA, pp. 265-269 1986

Techniques for Measuring the Shielding Effectiveness of Materials Proc., 7th Int. Symp. and Exhib. on Electromagn. Compat., 3-5 March, 1987, Zurich, Switzerland, pp. 547-552 1987

Techniques for Measuring the Electromagnetic Shielding Effectivenss of Materials: Part II -- Near-Field Source Simulation

IEEE Trans. on Electromagn. Compat., Vol. 30, No. 3, pp. 251-259

August 1988

Fields Radiated by Electrostatic Discharges

IEEE Trans. on Electromagnetic Compatibility, Vol. 33, No. 1, pp. $10-18$

February 1991 
WILSON, P. F.; CHANG, D. C.; MA, M. T.

Input Impedance of a Probe Antenna Exciting a TEM Cell

NBS Tech. Note 1054

April 1982

WILSON, P. F.; MA, M. T.; ADAMS, J.W.

Techniques for Measuring the Electromagnetic Shielding Effectivenss of

Materials: Part I - Far-Field Source Simulation

IEEE Trans. on Electromagn. Compat., Vol. 30, No. 3, pp. 239-250

August 1988

WILSON, P. F.; MA, M. T.; ONDREJKA, A. R.

Fields Radiated by Electrostatic Discharges

Proc., IEEE Int. Symp. on Electromagn. Compat.,

2-4 August, 1988, Seattle, WA, pp. 179-183 1988

WILSON, P. F.; CHANG, D. C.; MA, M. T.; CRAWFORD, M. L .

Theoretical and Experimental Analysis of Coupling Characteristics of

Dual TEM Cells

Record, IEEE 1983 Int. Symp. on Electromagn. Compat.,

23-25 August, 1983, Arlington, VA, pp. 513-517 1983

WILSON, P. F.; ONDREJKA, A. R.; MA, M. T.; LADBURY, J. M.

On the Electromagnetic Fields Radiated From Electrostatic Discharges Theory and Experiment

NBS Tech. Note 1314

February 1988

WU, D. I.; CHANG, D. C.

An Investigation of a Ray-Mode Representation of the Green's Function in a Rectangular Cavity

NBS Tech. Note 1312

september 1987

The Effect of a Large Rotating scatterer in a Rectangular Cavity NBS Tech. Note 1317 March 1988

A Hybrid Representation of the Green's Function in an Over-Moded Rectangular Cavity

IEEE Trans. on Microwave Theory and Techniques, Vol. 36,

No. 9, pp. 1334-1342

september 1988

The Effect of an Electrically Large Stirrer in a Mode-Stirred Chamber

IEEE Trans. on Electromagn. Compat., Vol. 31, No. 2,

pp. 164-169

May 1989

WU, D. I.; KANDA, M.

Comparison of Theoretical and Experimental Data for the Near-Field of an

Open Ended Rectangular Waveguide.

IEEE Trans. on Electromagnetic Compatibility.; Vol. 31,

No. 4, pp. 353-358.

November 1989 
WYSS, J. C. ; SHEERAN, S.

A Passive, Optical Modulator and Link for Antennas

IEEE J. of Lightwave Technol., Vol. LT-3, No. 2, pp. 316-321

April 1985

WYSS, J. C.; RANDA, M.; MELQUIST, D. G.; ONDREJKA, A. R.

Optical Modulator and Link for Broadband Antennas

Dig., 1982 Conf. on Precision Electromagn. Meas.,

28 June-1 July, 1982, Boulder, CO, pp. P-16 - P-17 1982 
ADAIR, R. T.

A Precision $30 \mathrm{MHz}$ Waveguide-Below-Cutoff Attenuator with an Absolute Electronic Readout, NBS Model XII

NBSIR 76-833

January 1976

ADAIR, R. T.; LIVINGSTON, E. M.

Coaxial "Intrinsic" Impedance Standards;

NIST Tech Note 1333.

October 1989

ADAIR, R. T.; RUSSELL, D. H.

A Calibration Service for $30 \mathrm{MHz}$ Attenuation and Phase shift SP $-250-32$

April 1988

ADAIR, R. T.; REEVE, G. R.; GATTERER, L. E.

Millimeter Wave Standards: An Emerging Need

Proc., IEEE Instrum. and Meas. Techn. Conf.,

25-27 March, 1986, Boulder, CO, Vol. IM-35, No. 4,

pp. $376-382$ 1986

The Expanding Need for Microwave and Millimeter Wave Calibration Services

NCSL Newsletter, Vol. 27, No. 1, pp. 21-31 January 1987

AGY, D. I.; NELSON, R. E.

An Immittance Transcomparator

1970 Annual Precision Measurement Association Metrology Conf. (3rd), 17-18 June, 1970, Gaithersburg, MD, Vol. 1, pp. 147-154 1970

ALLRED, C. M.; MANNEY, C. H . Self-Calibration of Complex Ratio Measuring system

Proc., 1973 Int. Conf. Meas. and Instrum., 17-23 June, 1973, Dresden, Germany, ACTA IMEKO 1, pp. 157-166 1973

The Calibration and Use of Directional Couplers Without standards IEEE Trans. Instrum. Meas., Vol. IM-25, pp. 84-89 March 1976

BEATTY, R. W.

Impedance Measurements and Standards for Uniconductor Waveguide Proc., IEEE, Special Issue on Radio Meas. Methods and Standards, Vol. 55, No. 6, pp. 933-941 June 1967

CLAGUE, F. R.

The NIST Automated Coaxial Microwave Power Standard Proc., 1989 Measurement Science Conf., 26-27 January, 1989, Anaheim, CA, pp. $1 \mathrm{C}-1-1 \mathrm{C}-14$ 1989

Power Measurement system for $1 \mathrm{~mW}$ at $1 \mathrm{GHz}$ NIST Tech Note 1345

November 1990 
CLAGUE, F. R.; LARSEN, N. T.

A Transient Response Error in Microwave Power Meters Using Thermistor Detectors

28th ARFTG Conf. Dig., 4-5 December, 1986, st. Petersburg Beach, FL, pp. 79-89

1986

COOR, C. C.; ALLRED, C. M.

An Excitation System for Piston Attenuators

IEEE Trans. Instrum. Meas., Vol. IM-20, pp. 10-16

February 1971

COUNAS, G. J.; YATES, B. C.

Measurement of Adapter Loss, Mismatch, and Efficiency Using the Dual

six-port

$$
\begin{array}{ll}
\text { NBSIR } & 88-3095 \\
\text { July } 1988
\end{array}
$$

CRAWFORD, M. L.; SMART, G. R.

New Coaxial Thermistor Mounts for use as Precision Transfer Standards

Proc., 1970 Instrument Soc. of America Conf., 26-29 October, 1970, Philadelphia, PA, N708-70, pp. 1-6

1970

DRIVER, L. D.; RIES, F. X.; REBULDELA, G.

NBS RF Voltage Comparator

NBSIR 78-871

December 1978

EBBESEN, H.; ENGEN, G. F.

Singularities in Calibration of Six-port Network Analyzers

1981 IEEE MTT-S Int. Microwave Symp. Dig., p. 149 1981

ELLERBRUCH，D. A.

UHF and Microwave Phase-Shift Measurements

Proc., IEEE, Special Issue on Radio Meas. Methods and Standards,

Vol. 55, No. 6, pp. 960-969 June 1967

ENGEN, G. F.

An Introduction To The Description and Evaluation of Microwave Systems

Using Terminal Invariant Parameters

NBS MN 112

October 1969

A New Method of Characterizing Amplifier Noise Performance

IEEE Trans. Instrum. Meas., Vol. IM-19, pp. 344-349

November 1970

An Extension to the Sliding Short Method of Connector and Adaptor Evaluation

NBS J. Res. Vol. 75C, pp. 177-183 1971 
ENGEN, G. F. (cont.)

Power Equations: A New Concept in the Description and Evaluation of Microwave systems

IEEE Trans. Instrum. Meas., Vol. IM-20, pp. 49-57 February 1971

Theorem Giving Limits for $S_{22}$ when $S_{11}$ and the Two-Port Efficiency are known

IEEE Trans. Instrum. Meas., Vol. IM-20, p. 78

February 1971

Theory of UHF and Microwave Measurements Using the Power Equation concept

NBS Tech. Note 637

April 1973

Mismatch Considerations in Evaluating Amplifier Noise Performance

IEEE Trans. Instrum. Meas., Vol. IM-22, pp. 274-278 September 1973

Calibration of an Arbitrary Six-Port Junction for Measurement of Active and Passive Circuit Parameters

IEEE Trans. Instrum. Meas., Vol. IM-22, pp. 295-299 December 1973

Comments on Practical Analysis of Reflectometers and Power Equation Concepts

IEEE Trans. Instrum. Meas., Vol. IM-23, pp. 104-105 March 1974

An Alternative Calibration Technique for Automated Network Analyzers with Application to Adapter Evaluation

Proc., 1974 IEEE S-MTT Int. Microwave Symp., 12-14 June, 1974,

Atlanta, GA, Microwave Symposium Digest, pp. 261-262 1974

Calibration Technique for Automated Network Analyzers with Application to Adapter Evaluation

IEEE Trans. Microwave Theory Tech. Part II, 1974 Symp. Issue, Vol. MTT-22, pp. 1255-1260. December 1974

Automated Calibration of Directional-Coupler-Bolometer-Mount Assemblies Proc., 1975 IEEE Microwave Theory and Technique symp. Int., 12-14 May, 1975, Palo Alto, CA, pp. 98-99 1975

IEEE Trans. Microwave Theory Techn., Vol. MTT-23, pp. 984-990 December 1975

Measurement of Complex Microwave Circuit Parameters Using Only Power Detectors

Proc., 1976 Conf. on Precision Electromagn. Meas.,

28 June-1 July, 1976, Boulder, CO, p. 171 1976 
ENGEN, G. F. (cont.)

Determination of Microwave Phase and Amplitude from Power Measurements IEEE Trans. Instrum. Meas., Vol. IM-25, pp. 414-418 December 1976

An Improved Circuit for Implementing the Six-Port Technique of Microwave Measurements

1977 IEEE-MTT-S Int. Microwave Symp., 21-23 June, 1977,

San Diego, CA, pp. 53-55 1977

IEEE Trans. Microwave Theory Techn., Vol. MTT-25, pp. 1080-1083

December 1977

The Six-Port Reflectometer: An Alternative Network Analyzer

Proc., 1977 IEEE-MTT-S Int. Microwave Symp.,

21-23 June, 1977, San Diego, CA, pp. 44-46 1977

Design Considerations for Automatic Network Analyzers Based on the Six-Port Concept

Proc., IEE Euromeas 1977 Conf., 1-9 September, 1977, Sussex, England; London, England, pp. 110-111 1977

Instrumentation: Six Ports Simplify Network Microwave syst. News, pp. 54-55 January 1978

Advances in Microwave Measurement Science

Proc., IEEE, Vol. 66, pp. 374-384 April 1978

The Six-Port Measurement Technique: A Status Report

Microwave J., Vol. 21, pp. 18,21-22,24,84,87,89 May 1978

Calibrating the six-port Reflectometer by Means of sliding Terminations IEEE Trans. Microwave Theory Techn., Vol. MTT-26, pp. 951-957 December 1978

A Least Squares Solution for Use in 6-port Measurement Technique IEEE Trans. Microwave Theory Techn., Vol. MTT-28, No. 12 December 1980

Redundancy: A Monitor of Six-Port Performance Dig., IEEE 1983 Colloquium on Advances in S-Parameter Measurement at Microwave Lengths, 23 May, 1983, Savoy Place, London, England, No. $1983 / 53$, pp. 4-1 - 4-2 1983

In Search of a More Realistic Accuracy Statement for Microwave Metrology Dig., 27th Automatic RF Techniques Group, 5-6 June, 1986, Baltimore, MD, pp. 181-183 1986 
ENGEN, G. F. (cont.)

On-Line Accuracy Assessment for the Dual Six-Port ANA: Background and Theory

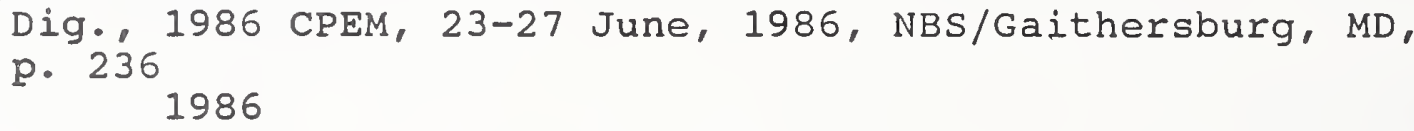

IEEE Trans. on Instrum. and Meas., Vol. IM-36, No. 2, pp. 501-506

June 1987

ENGEN, G. F.; HOER, C. A.

Application of an 'Arbitrary' 6-Port Junction to Power Measurement Problems

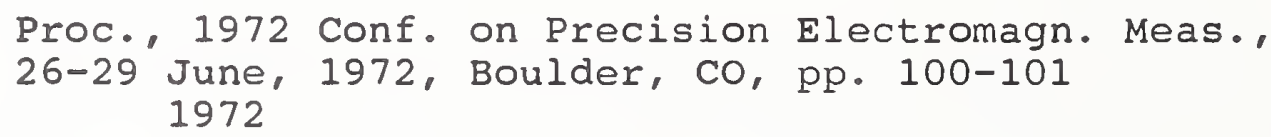

IEEE Trans. Instrum. Meas., Vol. IM-21, pp. 470-474 November 1972

Through-Load-Delay: An Improved Technique for Calibrating the Dual Six-port Automatic Network Analyzer

Int. Microwave Symp. Dig., Orlando, FL, p. 53 1979

ENGEN, G. F.; HUDSON, P. A.

International Intercomparison of Power Standards at $3 \mathrm{GHz}$

IEEE Trans. Microwave Theory Techn., Vol. MTT-19, pp. 411-413 April 1971

ENGEN, G. F.; HOER, C. A.; SPECIALE, R. A.

The Application of "Through-Short-Delay" to the Calibration of the Dual six-port

IEEE Int. Microwave Symp. Dig., pp. 184-185 1978

ESTIN, A. J.

A Calculable Microwave Attenuation Standard: The High Q Cavity Proc., 1972 Conf. on Precision Electromagn. Meas., 26-29 June, Boulder, CO, pp. 100-101 1972

Scattering Parameters of SMA Coaxial Connectors

IEEE Trans. Instrum. Meas., Vol. IM-25, No. 4, pp. 329-334 1976

FOOTE, W. J.; HUNTER, R. D.

Improved Gearing for Rotary-Vane Attenuators

Rev. Scientific Instrum., Vol. 43, No. 7, pp. 1042-1043 July 1972

GINLEY, R. A.; ALLRED, C. M.

1.25 MHz Attenuation Measurement system

Proc., IEEE Instrum. and Meas. Techn. Conf., 25-27 March, 1986, Boulder, CO, Vol. IM-35, No. 4, pp. 463-466 1986 
HILL, D. A.; WAIT, J.R.

Propagation Along a Coaxial Cable with a Helical shield

IEEE Trans. Microwave Theory Techn., Vol. MTT-28, No. 2, pp. 84-89

February 1980

Electromagnetic Theory of the Loosely Braided Coaxial Cable: Part II Numerical Results

IEEE Trans. Microwave Theory Techn., Vol. MTT-28, No. 4, pp. $326-331$

April 1980

HOER, C. A.

The Six-Port Coupler; A New Approach to Measuring V, I, P, Z, and Theta

Dig., 1972 Conf. Precision Electromagn. Meas.,

26-29 June, 1972, Boulder, CO, pp. 6-29

1972

The Six-Port Coupler: A New Approach to Measuring Voltage, Current, Power, Impedance, and Phase

IEEE Trans. Instrum. Meas., Vol. IM-21, pp. 466-470 November 1972

Using Six-Port and Eight-Port Junctions to Measure Active and Passive Circuit Parameters

NBS Tech. Note 673

September 1975

A Microwave Network Analyzer Using Two 6-Port Reflectometers;

Proc., 1977 IEEE-MTT-S Int. Microwave Symp.,

21-23 June, 1977, San Diego, CA, pp. 47-49 1977

A Network Analyzer Incorporating Two 6-Port Reflectometers

IEEE Trans. Microwave Theory Techn., Vol. MIT-25,

pp. 1070-1074

December 1977

Calibrating Two Six-Port Reflectometers with only one Impedance standard NBS Tech. Note 1004

June 1978

Calibrating Two Six-Port Reflectometers with an Unknown Length of

Precision Transmission Line

Proc., 1978 IEEE MTT-S Int. Microwave Symp. Dig.,

27-29 June, 1978, Ottawa, Canada, pp. 176-178 1978

Calibrating a Six-Port Reflectometer with Four Impedance standards NBS Tech. Note 1012 March 1979

Performance of a Dual Six-Port Automatic Network Analyzer

Proc., IEEE MTT-S 1979, Int. Microwave Symp. Dig.: The World of Microwaves, 3 April-2 May, 1979, Orlando, FL, IEEE Cat. No. 79CHI439-9 MTT-S

1979 
HOER, C. A. (cont.)

A High Power Dual Six-port Automatic Network Analyzer Used in Determining Biological Effects of RF and Microwave Radiation

IEEE Trans. Microwave Theory Techn., Vol. MTT-29 December 1981

Choosing Line Lengths for Calibrating Network Analyzers IEEE, Vol. MTT-31, No. 2, pp. 76-78 January 1983

Multiport Network Analyzers

McGraw-Hill Yearbook of Science and Technol., pp. 289-292 1986

On-Line Accuracy Assessment for the Dual Six-Port ANA; Treatment of Systematic Errors

Dig., 1986 CPEM, 23-27 June, 1986, NBS/Gaithersburg, MD, pp. $238-239$

1986

IEEE Trans. on Instrum. and Meas., Vol. IM-36, No. 2, pp. 514-519

June 1987

Some Questions and Answers Concerning Air Lines as Impedance Standards. Dig., 29th Automatic RF Techniques Group; 12-13 June, 1987; Las Vegas, NV; pp. 161-173. 1987

An Equivalent Circuit for Imperfect Transmission Line Connectors CPEM Dig., 7-10 June, 1988, Tsukuba Science City, Japan, pp. 264-265 1988

Systematic Errors in Power Measurements Made with a Dual Six Port ANA; NIST Tech Note 1332

July 1989

HOER, C. A.; AGY, D. L.

Broad-Band Resistive-Divider-Type Directional Coupler

IEEE Trans. Instrum. Meas., Vol. IM-19, pp. 336-343 November 1970

HOER, C. A.; ENGEN, G. F.

Analysis of a Six-Port Junction for Measuring, V, I, A, B, Z, Gamma, and Phase

Proc., 1973 Conf. of the Int. Meas. Confederation (6th), 17-23 June, 1973, Dresden, Germany, Acta Imeko, Vol. 1, pp. $213-222$

1973

Calibrating a Dual six-Port or Four-Port for Measuring Two-Ports with Any Connectors

Dig., 1986 IEEE-MTT Symp., 2-4 June, 1986, Baltimore, MD, pp. 665-668

1986 
HOER, C. A.; ENGEN, G. F. (cont.)

On-Line Accuracy Assessment for the Dual Six-Port ANA: Extension to Non-Mating Connectors

Dig., 1986 CPEM, 23-27 June, 1986, NBS/Gaithersburg, MD, pp. $241-242$ 1986

IEEE Trans. on Instrum. and Meas., Vol. IM-36, No. 2, pp. 524-529

June 1987

HOER, C. A.; ROE, K. C.

Using an Arbitrary Six-Port Junction to Measure Complex Voltage Ratios IEEE Trans. Microwave Theory Techn., Vol. MTT-23, No. 12, pp. $978-984$

December 1975

HOER, C. A.; ROE, K. C.; ALLRED, C. M.

Measuring and Minimizing Diode Detector NonLinearity Proc., 1976 Conf. on Precision Electromagn. Meas., 28 June-1 July, 1976, Boulder, CO, pp. 108-109 1976

HOLT, D. R.

Determination of scattering Parameters from Precision Coaxial Air-Line Standards CPEM Dig., 7-10 June, 1988, Tsukuba Science City, Japan, p. 263

1988

Scattering Parameters Representing Imperfections in Precision Coaxial Air Lines

J. of Research of the NIST, Vol. 94, No. 2, pp. 117-133 March-April 1989

Determination of Scattering Parameters with Respect to thecharacteristic Impedance of Precision Coaxial Air-Line standards.

CPEM Digest; June 11-14, 1990; Ottawa, Canada; pp. 282-283. June 1990

HOLT, D. R. HOER, C. A.

Estimation of True Power Ratios in Six-port Network Analyzers Using

Diode Detectors

Proc., 1985 Instrum. and Meas. Technol. Conf., 20-22 March, 1985,

1985

Tampa, FL, pp. 140-141

IEEE Trans. on Instrum. and Meas., Vol. IM-34, No. 4, pp. 558-563

December 1985

HUDSON, P. A

Measurement of RF Peak Pulse Power

Proc., IEEE, Special Issue on Radio Meas. Methods and Standards, Vol. 55, No. 6 , pp. 851-855

June 1967 
HUDSON, P. A. (cont.)

The National Measurement system for Medical Ultrasonics NBSIR 75-937

February 1976

HUDSON, P. A.; SAULSBERY, L. F .

An Adjustable-Slot-Length UHF Coaxial Coupler with Decade Bandwidth

IEEE Trans. Microwave Theory Techn., Vol. MTT-19, pp. 781-783 September 1971

HUDSON, P. A.; MELQUIST, D. G •; ONDREJKA, A. R .; WERNER, P. E. Completion of the Program to Evaluate/Improve Instrumentation and Test Methods for Electroexplosive Device Safety Qualification NBSIR 74-379

June 1974

HUNTLEY, L. E.; JONES, R. N.

Lumped Parameter Impedance Measurements

Proc., IEEE, Special Issue on Radio Meas. Methods and Standards, Vol. 55, No. 6, pp. 900-911

June 1967

JESCH, R. L.

Impedance Measurements in Coaxial Waveguide Systems

Proc., IEEE, Special Issue on Radio Meas. Methods and Standards, Vol. 55, No. 6, pp. 912-923

June 1967

Repeatability of SMA Coaxial Connectors

IEEE Trans. Instrum. Meas., Vol. IM-25, No. 4, pp. 314-320 December 1976

Evaluation of Low-Loss/Low-Reflection Two-Port Devices or Adapters by Automated Measurement Techniques

NBSIR 78-870

December 1977

JESCH, R. L.; HOER, C. A.

Characterization of a High Frequency Probe Assembly for Integrated Circuit Measurements

NBS Tech. Note 663

January 1975

JONES, R. N.

The Measurement of Lumped Parameter Impedance

NBS MN 141

June 1974

Evaluation of Three-Terminal and Four-Terminal Pair Capacitors at High Frequencies

NBS Tech. Note 1024

September 1980

A Comparison of Centrifuge and Freezing Calorimeter Methods for Measuring Free water in snow

NBSIR 79-1604

April 1979 
JONES, R. N.; HUNTLEY, L. E.

A Precision, High Frequency Calibration Facility for Coaxial Capacitance Standards

NBS Tech. Note 386

March 1970

JUDISH, R. M.

Quality Control of Measurements--Measurement Assurance

Proc., IEEE Spec. Issue on Radio Meas. Methods and Standards,

Vol. 74, No. 1, pp. 23-25

January 1986

On-Line Accuracy Assessment for the Dual Six-Port ANA: Statistical

Methods for Random Errors

Dig., 1986 CPEM, 23-27 June, 1986, NBS/Gaithersburg, MD,

p. 237

1986

JUDISH, R. M.; ENGEN, G. F.

On-Line Accuracy Assessment for the Dual Six-port ANA: statistical

Methods for Random Errors

IEEE Trans. on Instrum. and Meas., Vol. IM-36, No. 2,

pp. 507-513

June 1987

JUDISH, R. M.; JONES, R. N.

A Generalized Method for the Calibration of Four-Terminal-Pair Type

Digital Impedance Meters

NBSIR 84-3016

August 1984

JUROSHER, J.R.

On-Iine Accuracy Assessment for the Dual Six-Port ANA: Experimental Results

Dig., 1986 CPEM, 23-27 June, 1986, NBS/Gaithersburg, MD, p. 240

1986

IEEE Trans. on Instrum. and Meas., Vol. IM-36, No. 2, pp. 520-523

June 1987

A study of Measurement of Connector Repeatability Using Highly Reflecting Loads

IEEE Trans. on Microwave Theory and Techniques, Vol. MTT-35, No.4, pp. $457-460$

April 1987

JUROSHER, J. R.; HOER, C. A.

A Dual Six-port Network Analyzer Using Diode Detectors

IEEE Trans. Microwave Theory Technol., Vol. MTT-32, No. 1, pp. 78-82

$$
\text { January } 1984
$$


JUROSHEK, J.R.; HOER, C. A. (cont.)

A High-Power Automatic Network Analyzer for Measuring the RF Power Absorbed by Biological samples in a TEM Cell

IEEE Trans. Microwave Theory Technol., Vol. MTT-32, No. 8, pp. 818-824

August 1984

A Technique for Extending the Dynamic Range of the Dual Six-port Network Analyzer

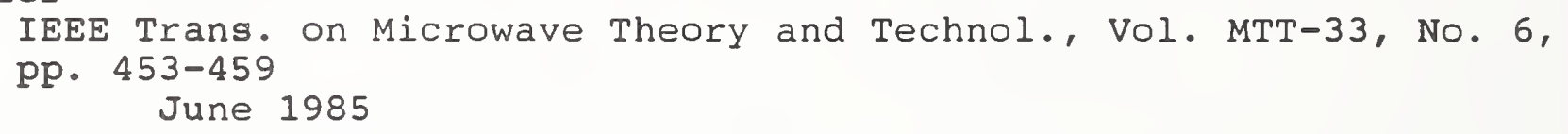

JUROSHEK, J.R.; HOER, C. A.; KAISER, R. K. F.

Calibrating Network Analyzers with Imperfect Test Ports IEEE Trans. on Instrum. and Meas., Vol. 38, No. 4, pp. 898-901

August 1989

RAMPER, R. A.

The National Electromagnetic Measurement system NBSIR 75-936

June 1977

Status of RF and Microwave Calibration Services at NBS

Nat. Conf. of Standards Laboratories Newsletter, Vol. 18, No. 3 , p. 40

December 1978

Current Trends in NBS Calibration Services

Nat. Conf. of Standards Laboratories Newsletter, Vol. 22,

No. 1 , pp. 38-39

March 1982

KAMPER, R. A.; HOER, C. A.

Millimeter Wave Standards at the National Bureau of Standards (NBS)

Proc., The Int. Soc. for Optical Engineering (SPIE),

23-24 August, 1983, San Diego, CA, Vol. 423, pp. 144-146 1983

KANDA, M.; MAY, W. G.

A Millimeter Wave Reflection Beam Isolator

IEEE Trans. Microwave Theory Technol., Vol. MTT-23, No. 6, pp. 506-508

June 1975

RERNS, D. M.

Definitions of $v, i, Z, Y, a, b, \Gamma$, and $s$

Proc., IEEE, Special Issue on Radio Meas. Methods and Standards,

Vol. 55, No. 6, pp. 892-900

June 1967

KOMAREK, E. I.

An Application of the Power Equation Concept and Automation Techniques

to Precision Bolometer Unit Calibration

Proc., 1974 IEEE S-MTT Int. Microwave Symp., 12-14 June, 1974,

Atlanta, GA, Microwave Symposium Digest, pp. 263-265 1974 
KOMAREK, E. L. (cont.)

An Automated Broadband System for Measurement of One-Port Microwave Parameters

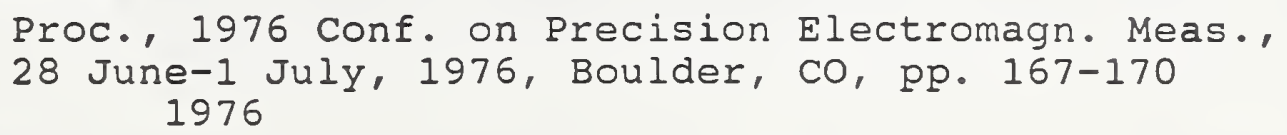

An Application of the Six-Port Junction to Precision Measurement of Microwave One-Port Parameters

Proc., 1977 IEEE-MTT-S Int. Microwave Symp.,

21-23 June, 1977, San Diego, CA, pp. 56-57 1977

Performance Characteristics of an Automated Broad-Band Bolometer Unit Calibration System

IEEE Trans. Microwave Theory, Vol. MTT-25, pp. 1122-1127 December 1977

Advantages of the Six-port Reflectometer for RF/Microwave Power Measurement in Operational systems

Government Micro-Circuit Applications Conf. Dig. 1978

KOMAREK, E. L.; TRYON, P. V.

An Application of the Power Equation Concept and Automation Techniques to Precision Bolometer Unit Calibration

IEEE Trans. Microwave Theory Techn. Part II, 1974 Symp. Issue, Vol. MTT-22, pp. 1260-1267

December 1974

LARSEN, N. T.

A New Self-Balancing DC-Substitution RF Power Meter

Proc., 1976 Conf. on Precision Electromagn. Meas., 28 June-1 July, 1976, Boulder, CO, pp. 203-205 1976

IEEE Trans. Instrum. Meas., Vol. IM-25, pp. 343-347 December 1976

NBS Type IV RF Power Meter Operation and Maintenance

NBSIR 77-866 October 1977

Microwave Power standards at the National Bureau of Standards 1987 NCSL Workshop and Symp., 12-16 July, 1987, Denver, CO, pp. $34-1-34-7$ 1987

LARSON, W.; CAMPBELI, E.

Microwave Attenuation Measurement system (Series substitution)

NBS Tech. Note 647 February 1974

LAWTON, R. A.; ALLRED, C. M.; HUDSON, P. A.

A Wide Range CW Power Measurement Technique

IEEE Trans. Instrum. Meas., Vol. IM-19, pp. 28-34 February 1970 
LITTLE, W. E.; YATES, B. C.

Reflection Coefficient Standards for Automated Network Analyzers

Proc., 1976 Conf. on Precision Electromagn. Meas.,

28 June-1 July, 1976, Boulder, CO, pp. 128-129 1976

LITTLE, W. E.; WAREFIELD, J. P.; HEIM, L.; ALLRED, C. M.; ZAPF。 T. L. An NBS Developed Automatic Network Analyzer

Proc., 1976 Conf. on Precision Electromagn. Meas.,

28 June-1 July, 1976, Boulder, CO, pp. 382-385 1976

LIVINGSTON, E. M.; ADAIR, R. T.

Performance Evaluation of Radiofrequency, Microwave and Millimeter Wave

Power Meters

NBS Tech Note 1310

December 1988

MAJOR, J.R.; LIVINGSTON, E. M.; ADAIR, R. T.

Automatic Frequency Response of Frequency Modulated Generators Using the Bessel Null Method

Dig., 24th Automatic RF Techniques Group Conf., 5-6 December,

1984, Columbia, MD, pp. 131-153 1984

Proc., 1985 Test and Measurement World Expo, 14-16 May, 1985, San Jose, CA, pp. 78-100 1985

NBS Tech. Note 1093

March 1986

MARKS, R. B.

Comments on "Improved Calibration and Measurement of the scattering Parameters of Microwave Integrated Circuits"

IEEE Trans. on Microwave Theory \& Techniques, Vol. 38, No. 4, p. 453

April 1990

Multi-Line Calibration for MMIC Measurement

Digest, 36th ARFTG Conf., 29-30 Nov. 1990, Monterey, CA, pp. 47-55 November 1990

A Multiline Method of Network Analyzer Calibration

IEEE Trans. on Microwave Theory \& Techniques, Vol. 39, No. 7, p. 1205-1215

July 1991

MARKS, R. B.; PHILLIPS, K. R.

Wafer-Level ANA Calibrations at NIST

Digest, 3Ath ARFTG Conf., Nov. 30 - Dec. 1, 1989, Ft. Lauderdale,

FL, pp. 11-25

December 1989 
MARKS, R. B.; WIILIAMS, D. F.

Characteristic Impedance Determination Using Propagation Constant Measurement

IEEE Microwave and Guided Wave Letters, Vol. 1, No. 6, p. 141-143 June 1991

NAHMAN, N. S.

A Note on the Transition (Rise) Time Versus Line Length in Coaxial

Cables

IEEE Trans. Circuit Theory, Vol. CT-20, pp. 165-167 March 1973

ONDREJKA, A. R.

Peak Pulse Voltage Measurement (Baseband Pulse)

Proc., IEEE, Special Issue on Radio Meas. Methods and Standards, Vol. 55, No. 6, pp. 882-885 June 1967

PHILIIPS, R. R.; WILIIAMS, D. F.

MMIC Package Characterization with Active Loads

Digest, 36th ARFTG Conf., 29-30 Nov. 1990, Monterey, CA, pp. 64-72 November 1990

REEVE, G. R.; ARTHUR, M. G.

A standard for RF Modulation Factors

NBS Tech. Note 1016

September 1979

REEVE, G. R.; MILLER, C. K. S .

Current NBS Metrology Capabilities and Limitations at Millimeter Wave Frequencies

Proc., 1985 Meas. Science Conf., 17-18 January, 1985,

Santa Clara, CA, pp. 296-314

1985

REEVE, G. R.; MARKS, R. B.; BLACKBURN, D.

MMIC Related Metrology at the National Institute of standards and Technology.

Record, Instrumentation \& Measurement Technology (IMTC) Conf.;

February 13-15, 1990; San Jose, CA; pp. 196-199. 1990

Microwave Monolithic Integrated Circuit-Related Metrology at the National Institute of Standards and Technology

IEEE Trans. on Instrumentation \& Measurement, Vol. 39, No. 6, pp. 958-961

December 1990

RIES, F. $\mathbf{X}$.

An International Intercomparison of Voltage standards at $1 \mathrm{GHz}$ in Coaxial Transmission Line

IEEE Trans. on Instrum. and Meas., Vol. IM-25, p 4.

September 1976 
ROE, K. C.; HOER, C. A.

A Microwave Vector Voltmeter system

NBSIR 76-844

August 1976

RUMFELT, A. Y.: ELWELU, I. B .

Radio Frequency Power Measurements

Proc., IEEE, Special Issue on Radio Meas. Methods and Standards, Vol. 55, No. 6, pp. 837-850 June 1967

RUSSEIL, D. H.

An Unmodulated Twin-Channel Microwave Attenuation Measurement System; ISA Trans., Vol. 4 , pp. 162-169 April 1965

RUSSELL, D. H.; LARSON, W.

RF Attenuation

Proc., IEEE, Special Issue on Radio Meas. Methods and Standards, Vol. 55, No. 6, pp. 942-959 June 1967

SAULSBERY, I. F.; ADAIR, R. T.

ANA Measurement Results on the ARFTG Traveling Experiment

Conf. Dig., 28th Automatic RF Techniques Group, 4-5 December, 1986, St. Petersburg Beach, FL, pp. 65-78 1987

SCOTT, W. W. Jr.

A New Coaxial RF-DC Ammeter

Proc., 1970 Dig. on Precision Electromagn. Meas. Conf.,

2-5 June, 1970, Boulder, CO, Special Issue CPEM Digest p. 13 1970

SCOTT, W. W., Jr.; FREDERICK, N. V.

The Measurement of Current at Radio Frequencies

Proc., IEEE, Special Issue on Radio Meas. Methods and Standards,

Vol. 55, No. 6 , pp. 886-891 June 1967

SELBY, M. C.

Voltage Measurement at High and Microwave Frequencies in Coaxial Systems Proc., IEEE, Special Issue on Radio Meas. Methods and Standards, Vol. 55, No. 6, pp. 877-882 June 1967

SEQUEIRA, H. B.; YATES, B. C. Approach for Evaluating Effects of Wall Losses on Quarter-Wave Losses on Quarter-Wave Short-Circuit Impedance standards

IEEE Trans. on Microwave Theory and Techniques, Vol. MTT-33,

No. 11, pp. 1106-1109

November 1985 
SHERWOOD, G. V.

Air Gage Size Measurement of Microwave Standards Proc., 1991 Measurement Science Conf. Jan. 31 - Feb. 1, 1991, Anaheim, CA, pp. 1-10 1991

SIMPSON, P. A.

Broadband Pulsed/CW Calibration Signal Standard for Field Intensity

Meter (FIM) Receivers

NBSIR 74-371

June 1974

SIMPSON, P. A.; HUDSON, P. A.

Implementation of the Notch Technique as an RF Peak Pulse Power Standard NBS Tech. Note 682 July 1976

SIMPSON, P. A.: ONDREJKA, A. R.

Improvements to the NBS RF Peak-Pulse Power standard 1970 Instrument Soc. of America Silver Jubilee Int. Conf. and Exhibit, October, 1970, Philadelphia, PA, Paper 709-70, pp. $1-7$ 1970

SLADER, M. J.; JESCH, R. L.

Standardization of Coaxial Connections in the IEC

Proc., IEEE Spec. Issue on Radio Meas. Methods and Standards, pp. $14-18$

$$
\text { January } 1986
$$

WEIDMAN, M. P.

A Semi-Automated Six-Port for Measuring Millimeter Wave Power and Complex Reflection Coefficient

Proc., 1977 IEEE-MTT-S Int. Microwave Symp.,

21-23 June, 1977, San Diego, CA, pp. 58-60 1977

IEEE Trans. Microwave Theory Technol., Vol. MTT-25, pp. 1083-1085

December 1977

WR-10 Single Six-port Measurement system

NBSIR 81-1650

September 1981

Finline Diode Six-Port: Fundamentals and Design Information

NBS Tech. Note 1090

December 1985

WEIDMAN, M. P.; CAMPBELL, E.

A Method for Designing Multi-screw Waveguide Tuners

NBS Tech. Note 393

October 1970

WEIDMAN, M. P.; ENGEN, G. F.

Application of a Non-Ideal sliding short to Two-Port Loss Measurement NBS Tech. Note 644

october 1973 


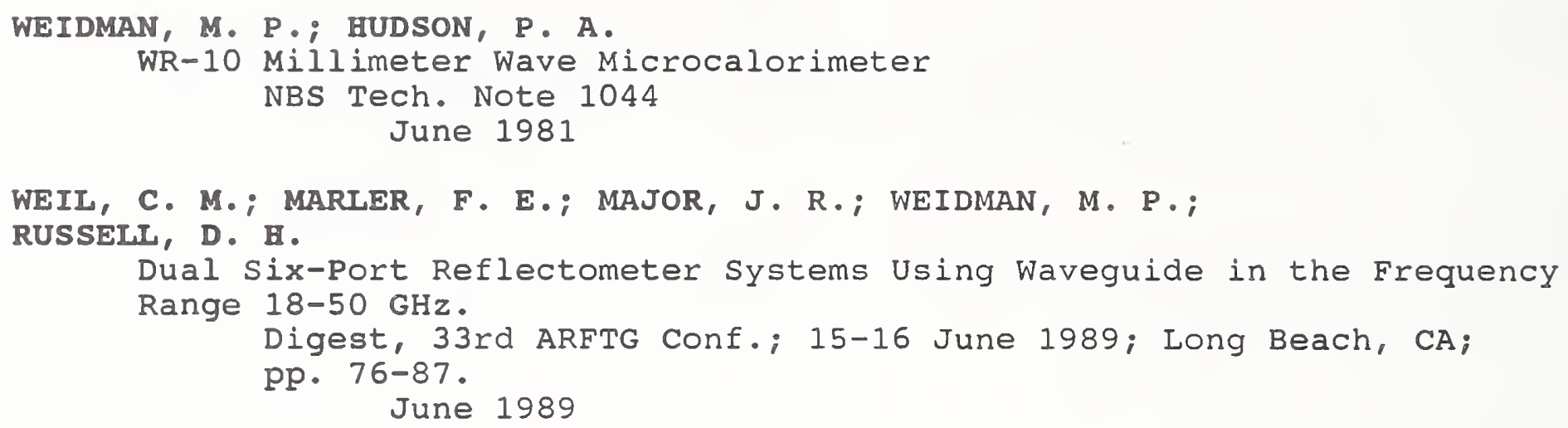

YATES, B. C.; COUNAS, G. J.

Summary of WR15 Flange Evaluation at $60 \mathrm{GHz}$ NBS Tech. Note 642 October 1973

YATES, B. C.; LARSON, W.

Millimeter Attenuation and Reflection Coefficient Measurement system NBS Tech. Note 619

July 1972 
ARTHUR, M. G.

A Precision HF-Noise Power Measurement System

Instr. Soc. Amer. ISA-70 Conf., October, 1971 1971

The Measurement of Noise Performance Factors: A Metrology Guide NBS MN 142 June 1974

BOYLE, D. R.; CLAGUE, F. R.; REEVE, G. R.; WAIT, D. F.; KANDA, M.

An Automated Precision Noise Figure Measurement system at $60 \mathrm{GHz}$ IEEE Trans. Instrum. Meas., Vol. IM-21, No. 4, pp. 543-549 November 1972

COUNAS, G. J.

NBS $2.0 \mathrm{GHz}$ to $4.0 \mathrm{GHz}$ Automated Radiometer Operation and Service Manual NBSIR 84-1697 January 1984

COUNAS, G. J.; BREMER, T. H. NBS 30/60 Megahertz Noise Measurement System Operation and Service Manual

NBSIR 81-1656

December 1981

DAYWITT, W. C.

A Reference Noise Standard for Millimeter Waves IEEE Trans. Microwave Theory Technol., Vol. MTT-21, No. 12, pp. $845-847$

December 1973

Error Equations Used in the NBS Precision G/T Measurement System NBSIR 76-842

september 1976

A Precision Earth-Terminal system for Accurate C/KT, G/T, and EIRP Measurements with a Calibrated Radio Star

Proc., 1977 URSI Int. Symp. On Meas. in Telecommunications, 3-7 october, 1977, Lannion, France, pp. 1-4 1977

Error Equations Used in the NBS Earth-Terminal Measurement system NBSIR 78-869

December 1977

Atmospheric Propagation Equations Used in the NBS Earth Terminal

Measurement system

NBSIR 78-883

April 1978

An Error Analysis for the Measurement of Satellite EIRP using a Calibrated Radio star

IEEE Trans. Instrum. Meas., Vol. IM-27, No. 3, pp. 253-258 September 1978

Design and Error Analysis for the WR10 Thermal Noise standard NBS Tech. Note 1071

December 1983 
DAIWITI, W. C. (cont.)

An Error Analysis for the Use of Presently Available Lunar Radio Flux

Data in Broadbeam Antenna-system Measurements

NBS Tech. Note 1073

February 1984

Proc., 1984 Antenna Applications Symp., 19-21 september, 1984, University of Illinois, Urbana-Champaign, IL, pp. 1-26 1984

A Coaxial Noise standard for the $1 \mathrm{GHz}$ to $12.4 \mathrm{GHz}$ Frequency Range NBS Tech. Note 1074 March 1984

A Preliminary Investigation into using the sun as a Source for G/T Measurements NBSIR $84-3015$ August 1984

A Derivation for the Noise Temperature of a Horn-type Noise standard International Journal of Scientific Metrology, Metrologia, 21 pp. 127-133 1985

Broadband Noise Source Applications

Proc., 1985 Instrum. and Meas. Technol. Conf.,

20-22 March, 1985, Tampa, FL, pp. 165-166 1985

10-60 GHz G/T Measurements Using the Sun as a Source--A Preliminary study

NBSIR $86-3046$

April 1986

A Simple Technique for Determining Joint Losses on a Coaxial Line from Swept-Frequency Reflection Data

Dig., 1986 CPEM, 23-27 June, 1986, NBS/Gaithersburg, MD, p. 40 1986

IEEE Trans. on Instrum. and Meas., Vol. IM-36, pp. 468-473 June 1987

Complex Admittance of a Lossy Coaxial Open Circuit with a Hollow Center Conductor

Int. J. of Scientific Metrology, Metrologia, 24, pp. 13-22 1987

A Simple Technique for Investigating Defects in Coaxial Connectors IEEE Trans. on Microwave Theory and Techniques, Vol. MTT-35, No. 4 , pp. 460-464 April 1987

Radiometer Equation and Analysis of systematic Errors for the NIST Automated Radiometers

NIST Tech Note 1327

March 1989

First Order Principal Mode Fields and Distributed Line Parameters for a Slightly Lossy Coaxial Transmission Line.

Digest, CPEM; June 11-14, 1990; Ottawa, Canada; pp. 404-405. June 1990 
DAYWITT, W. C. (cont.)

First Order Symmetric Modes for a Slightly Lossy Coaxial Transmission Iine

IEEE Trans. on Microwave Theory and Techniques, Vol. 38, no. 11. pp. $1644-1650$ November 1990

DAYWITT, W. C.; COUNAS, G. J . Measuring Adapter Efficiency Using a Sliding Short Circuit. IEEE Trans. on Microwave Theory and Techniques, Vol. 38 (No. 3), pp. 231-237 March 1990

DAYWITT, W. C.; RANDA, M.

G/T Measurement Errors with Radio Stars

Proc., 1975 IEEE Int. Antennas and Propagat. Symp.,

2-4 June, 1975, Urbana-Champaign, IL, Session 20, pp. 460-463 1975

DAYWITT, W. C.; FOOTE, W. J.; CAMPBELL, E.

WR15 Thermal Noise Standard

NBS Tech. Note 615

March 1972

ENGEN, G. F.

A New Method of Characterizing Amplifier Noise Performance

IEEE Trans. Instrum. Meas., Vol. IM-19, pp. 344-349 November 1970

Mismatch Considerations in Evaluating Amplifier Noise Performance

IEEE Trans. Instrum. Meas., Vol. IM-22, pp. 274-278 September 1973

ESTIN, A. J.; DAYWITT, W. C.

Evaluation of Signal Plus Noise Detection Error in an Envelope Detector with Logarithmic Compression

Proc., 1978 Conf. on Precision Electromagn. Meas.,

26-29 June, 1978, Ottawa, Canada 1978

NBSIR 79-1614(R)

August 1979

IEEE Trans. Inf. Theory, Vol. IT-17, No. 5, pp. 663-664 September 1981

GEYER, R. G .

Magnetostatic Measurements for Mine Detection

NISTIR 88-3098

October 1988

HALFORD, D.

Infrared-Microwave Frequency Synthesis Design: Some Relevant Conceptual Noise Aspects

Proc., 1971 Frequency Standards and Metrology Seminar,

30 August - 1 september, Quebec, Canada, pp. 431-466 1972

Comparing Frequencies

Physics Today, Vol. 26, No. 2, p. 15

February 1973 
HALFORD, D. (cont.)

Transparent Metrology of Signal to Noise Ratios of Noisy Band-limited Digital signals

NBS Tech. Note 1077

June 1985

KANDA, M.

A Measure for the stability of solid state Noise sources

Proc., 1975 IEEE Int. Microwave Theory and Technique Symp.,

12-14 May, 1975, Palo Alto, CA, pp. 315-317 1975

Study of Errors in Absolute Flux Density Measurements of Cassiopeia A NBSIR 75-822

october 1975

IEEE Trans. Instrum. Meas., Vol. IM-25, No. 3, pp. 173-182 September 1976

An Improved Solid state Noise Source

Proc., 1976 IEEE MTT-S Microwave Symp., 14-16 June, 1976,

Cherry Hill, NJ, pp. 224-226 1976

IEEE Trans. Instrum. Meas., Vol. IM-25, No. 3, pp. 173-182 September 1976

RANDA, M.; LARSON, T. R.

Stability of Silicon Avalanche Noise Diodes at $K$ and Ka Bands

Proc., 1976 Conf. on Precision Electromagn. Meas.,

28 June-1 July, 1976, Boulder, CO

1976

MILIER, C. K. S.; DAYWITT, W. C.

The NBS Switching Radiometers

NBSIR 84-3004

May 1984

The Reference Noise Standards NBS WR62 and WR90

NBSIR 84-3005

May 1984

MILLER, C. K. S.; DAYWITT, W. C.; ARTHUR, M. G.

Noise Standards, Measurements, and Receiver Noise Definitions

Proc., IEEE, Special Issue on Radio Meas. Methods and Standards, Vol. 55, No. 6, pp. 865-877 June 1967

PERERA, $\mathbf{S}$.

Noise Temperature Measurements at the National Bureau of standards

Proc., 1985 Instrum. and Meas. Technol. Conf.,

20-22 March, 1985, Tampa, FL, pp. 159-160

1985

A Simple Noise Calibration Radiometer.

Digest, CPEM; June 11-14, 1990; Ottawa, Canada; pp. 32-33. June 1990

WAIT, D. F.

Considerations for the Precise Measurement of Amplifier Noise

NBS Tech. Note 640

1973 
WAIT, D. F. (cont.)

Earth Terminal Measurement system Operations Manual NBSIR 78-879 April 1978

Precision Measurement of Antenna System Noise Using Radio stars Dig., 1982 Conf. on Precision Electromagn. Meas., 28 June-1 July, 1982, Boulder, CO, p. F-17 1982

IEEE Trans. Instrum. Meas., Vol. IM-32, No. 1, pp. 110-116 March 1983

Earth Terminal Measurement system Operations Manual (Revised) NBSIR 83-1679(R) January 1983

The Impact of Automation on NBS Noise Temperature Measurements Proc., IEEE Spec. Issue on Radio Meas. Methods and Standards., pp. $117-120$ 1986

Comments Concerning On-Wafer Noise Parameter Measurements Digest, 36th ARFTG Conf., Nov. 29-30, 1990, Monterey, CA, pp. 5-15 November 1990

WAIT, D. F.; DAYWITT, W. C.

Preliminary Examination of $20 \mathrm{GHz} \mathrm{G} / \mathrm{T}$ Measurements of Earth Terminals NBSIR 83-1686 March 1983

Intercomparison of NBS Noise Calibration Services CPEM Dig., 7-10 June, 1988, Tsukuba Science City, Japan, pp. $209-210$ 1988

WAIT, D. F.; ENGEN, G. F.

Application of Radiometry to the Accurate Measurement of Amplifier Noise IEEE Trans. on Instrumentation and Measurement, Vol. 40, No. 2, pp. $433-437$ April 1991

WAIT, D. F.; COUNAS, G. J.; KESSEL, W.; BUCHHOLZ, F. IM. PTB - NIST Bilateral Comparison of Microwave Noise Power in Coaxial Transmission Line.

Digest, CPEM; June 11-14, 1990; Ottawa, Canada; pp. 34-35. June 1990

IEEE Trans. on Instrumentation and Measurements, Vol. 40, No. 2, pp. 449-454 April 1991

WAIT, D. F.; RANDA, M.; DAYWITT, W. C.; MILLER, C. K. S .

A Study of the Measurement of G/T Using Cassiopeia A NBSIR 74-382

october 1974

WAKEFIELD, J. P.

Addendum to Earth Terminal Measurement System Maintenance Manual

NBSIR 81-1641

October 1981 
BELSHER, D. R.

Feasibility study on the use of a Microwave system for the

Nondestructive Evaluation of Historic Adobe Structures NBSIR 79-1610 July 1979

BELSHER, D. R.; MCLAUGHLIN, R. G.; REPJAR, A. G.; BUSSEY, H. E. Detection of Lost Wells and Unknown Water-filled Voids in Coal Mines through Development of an Experimental Microwave System NBSIR 84-3017 September 1984

BEREUTER, W. A.; CHANG, D. C. Electromagnetic Remote Sensing of Inhomogeneous Media NBSIR 76-851 January 1977

BOYNE, H. S.; ELLERBRUCH, D. A. Microwave Measurements of Snow Stratigraphy and Water Equivalence Proc., The Western snow Conference April 1979

CHANG, A. T. C.; SHIUE, J. C.; BOYNE, H. S . ; ELLERBRUCH, D. A.; COUNAS, G. J . Preliminary Results of Passive Microwave snow Experiment During February and March 1978

$$
\begin{gathered}
\text { NASA-TP-1408, Rept-7802-F22, p. } 114 \\
1979
\end{gathered}
$$

CHEW, H.

Modeling of Oil Shale Retorts for Electromagnetic Sensing Techniques NBSIR 81-1653 November 1981

Electromagnetic Modeling of oil shale Retorts for Remote sensing Purposes

IEEE Trans. Geosci. \& Remote sensing, Vol. GE-20, No. 4, pp. 510-517

October 1982

COLLIER, R. S.; ELLERBRUCH, D. A.

RF (Radiofrequency) Total Mass Gauging in Large storage Containers:

Empty Tank Modes

NBSIR 73-346

October 1973

COLLIER, R. S.; ELLERBRUCH, D. A.; CRUZ, J. E.; STOKES, R. W.; LUFT, P. E.

Mass Quantity Gauging by RF Mode Analysis

NBSIR 73-318

June 1973

CRUZ, J. E.; ROGERS, E. H.; HIESTER, A. E.

Continuous Liquid Level Measurements with Time-Domain Reflectometry Advances in Cryogenic Engineering, Vol. 18,

pp. 323-327 (Paper $\mathrm{H}-4$ )

1973

ELIERBRUCH, D. A.

Electromagnetic Attenuation Properties of Clay and Gravel Soils NBSIR 74-381

August 1974 
ELLERBRUCH, D. A.; ADAMS, J. W.

Microwave Measurement of Coal Layer Thickness

NBSIR 74-387

September 1974

ELLERBRUCH, D. A. ; BELSHER， D. R.

FM-CW Electromagnetic Technique of Measuring Coal Layer Thickness NBSIR 76-840

May 1976

Electromagnetic Technique of Measuring Coal Layer Thickness

IEEE Trans. Geosci. Electron., GE16, No. 2, pp. 126-133

April 1978

ELLERBRUCH, D. A.; JESCH, R. L.; JONES, R. N.; BUSSEY, H. E.; BOYNE, H. S.

Electromagnetic scattering Properties of Soils and Snow

Proc., 1978 Int. Symp. on Remote Sensing of Environment (12th),

20-26 April, 1978, Ann Arbor, MI, Vol. 2, pp. 957-974 1978

ELLERBRUCH, D. A.; JOHNSON, R. B.; BELSHER, D. R.; YAGHJIAN, A. D.;

STEPPE, M. C.; FLEMING R. W.

High Resolution Sensing Techniques for Slope Stability Studies

Federal Highway Administration Report, FHWA-7-3-0001 March 1979

HILI, D. A.

Radio Propagation in a coal Seam and the Inverse Problem

NBS J Res., Vol. 89, No. 5, pp. 385-394

September-October 1984

Proc., 1985 Int. Symp. on Antennas and EM Theory,

26-28 August, 1985, Beijing, China, pp. 422-427 1985

Electromagnetic Wave Propagation in a Symmetrical coal seam

IEEE Trans. Antennas Propagat., Vol. AP-34, No. 2, pp. 244-247 February 1986

Fields of Horizontal Currents Located Above the Earth

IEEE Trans. on Geoscience and Remote Sensing, Vol. 26, No. 6, pp. $726-732$

November 1988

Magnetic Dipole Excitation of a Long Conductor in a Lossy Medium

IEEE Trans. on Geoscience and Remote Sensing, Vol. 26, No. 6, pp. 720-725

November 1988

Magnetic Dipole Excitation of an Insulated Conductor of Finite Length. IEEE Trans on Geoscience and Remote Sensing; Vol. 28(No. 3): pp. 289-294.

May 1990

HILI, D. A.; ANDERSON, L. R.

Propagation Along a Two-Wire Line Located at the Air-Earth Interface. IEEE Trans. On Geoscience and Remote Sensing; Vol. 28(No. 3): pp. 400-402.

May 1990 
MONTGOMERY, J. P.; CHANG, D. C.

Electromagnetic Boundary-Value Problems Based Upon a Modification of Residue Calculus and Function Theoretic Techniques NBS MN 164

June 1979

ROE, R. C.; WITTMANN, R. C.

Improved Coal Interface Detector

NBSIR 82-1663

May 1982

STOLTENBERG, R. E.

Detection of Human Intruders by Low Frequency Sonic Interferometric Techniques NBSIR 74-364

May 1974 
ADAMS, J. W.; ONDREJKA, A. R.; MEDLEY, H. W.

Time-Domain System for Indentification of the Natural Resonant

Frequencies of Aircraft Relevant to Electromagnetic Compatibility

Testing

NBSIR 87-3077

November 1987

ADAMS, J. W.; ONDREJKA, A. R.; CAVCEY, K. H.; CRUZ, J. E.; MEDLEY, H. W.; GROSVENOR, J. H.

Recent Improvements in Time-Domain EMC Measurement system;

NISTIR 89-3927

November 1989

ANDREWS, J. R.

Impulse Generator Spectrum Amplitude Measurement Techniques

IEEE Trans. Instrum. Meas., Vol. IM-25, No. 4, pp. 380-384 December 1976

ANDREWS, J. R.; BALDWIN, E. E.

Baseband Impulse Generator Useful to $5 \mathrm{GHz}$

Proc., 1975 IEEE Int. Symp. on Electromagn. Compat.,

7-9 October, 1975, San Antonio, TX, pp. 1-4 1975

ANDREWS, J. R.; GANS, W. L .

Time Domain Automatic Network Analyzer

L'Onde Electrique, Vol. 55(10), pp. 569-574

December 1975

GANS, W. L.; ANDREWS, J. R.

Time Domain Automatic Network Analyzer for Measurement of RF and Microwave Components

NBS Tech. Note 672

september 1975

GANS, W. L.; GEYER, R. G.; KLEMPERER, W. K.

Suggested Methods and Standards for Testing and Verification of

Electromagnetic Buried Object Detectors

NISTIR 88-3915

March 1990

GEYER, R. G .

Magnetostatic Measurements for Mine Detection;

NISTIR 88-3098.

October 1988

LAWTON, R. A.; ONDREJKA, A. R.

Standards for the Measurement of Impulsive Fields Radiated by a TEM Horn Antenna

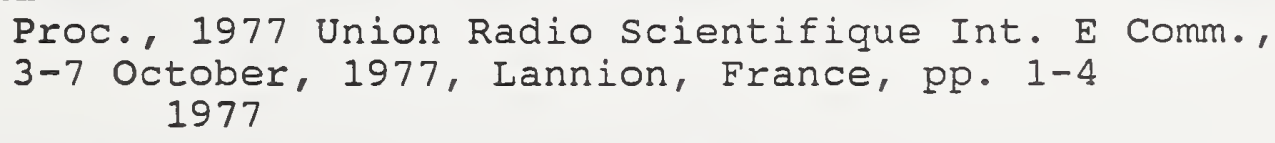

LAWTON, R. A.; RIAD, S. M.; ANDREWS, J.R. Pulse and Time Domain Measurements

Proc., IEEE, Special Issue on Radio Meas. Methods and Stds,

Vol. 74, No. 1, pp. 77-81

January 1986 
Time Domain (cont.)

NAHMAN, N. S.; JICKLING, R. M.

Frequency Domain Measurement of Baseband Instrumentation NBSIR 73-330

July 1973

NAHMAN, N. S.; JICKLING, R. M.; HOLT, D. R.

Reference-Waveform Generation Using Debye Dielectric Dispersion NBSIR 73-304

December 1972 


\section{WAVEFORM METROLOGY}

ANDREWS, $J$. R.

Improved Bias Supply for Tunnel-Diode Picosecond Pulse Generators IEEE Trans. Instrum. Meas., IM-19, pp. 171-175 August 1970

Horizontal Time Base Sweep Generator for a Traveling Wave oscilloscope IEEE Trans. Nucl. Sci., NS-18, pp. 3-18 october 1971

An Interfacing Unit for a 28 psec Feedthrough Sampling oscilloscope Rev. Sci. Instrum., Vol. 42, pp. 1882-1885 December 1971

A Frequency Calibrator for UHF Using an Avalanche Transistor

Q S T, Vol. 56, pp. 16-18 May 1972

Random Sampling oscilloscope Time Base NBSIR 73-309

June 1973

Random Sampling Oscilloscope for the Observation of Mercury Switch Closure Transition Times

IEEE Trans. Instrum. Meas., IM-22, pp. 375-381 December 1973

Inexpensive Laser Diode Pulse Generator for Optical Waveguide studies Rev. Sci. Instrum., Vol. 45 , pp. 22-24 January 1974

Precision Picosecond-Pulse Measurements Using a High Quality Superconducting Delay Iine

Proc. Conf. on Precision Electromagn. Meas., 1-5 July, 1974, London, England, pp. 316-318 1974

IEEE Trans. Instrum. Meas., IM-23, pp. 468-472 December 1974

Directional-Coupler Technique for Triggering a Tunnel Diode

IEEE Trans. Instrum. Meas., IM-24, pp. 275-277 september 1975

Impulse Generator Spectrum Amplitude Measurement Techniques CPEM Dig., pp. 23-24 1976

Measurement on Pulses and Pulse Transmission Media, Circuits and Components

URSI Review of Radio science, p. 9 1975-1977

The Estimation of the Pulse Waveform in the Calibration of Impulse Generators

Dig. of Papers, URSI/U. S. Nat. Radio Sci. Meeting, January, 1981, Boulder, CO, p. 87 1981 
ANDREWS, J. R. (cont.)

Pulse Reference Waveform Standards Development at NBS

Proc., ATE Seminar/Exhib., January, 1981, Pasadena, CA, p. IV.13-IV. 19

$$
1981
$$

ANDREWS, J. R.; BALDWIN, E. E.

Amplitude Calibrator for Oscilloscopes

NBSIR 81-1646

April 1981

ANDREWS, J. R.; GANS, W. L.

Pulsed Wavemeter Timing Reference for Sampling Oscilloscope Calibration IEEE Trans. Instrum. Meas., IM-24, p. 82 March 1975

ANDREWS, J.R.; LAWTON, R. A.

Picosecond Pulse Research at NBS

Proc., Joint Meas. Conf., 12-14 November, 1974, Gaithersburg, MD, pp. $123-140$

1974

Electrically strobed Optical Waveform Sampling Oscilloscope

Rev. Sci. Instrum., Vol. 47, pp. 311-313 March 1976

ANDREWS, J.R.; NAHMAN, N. S.

Electron-Beam Deflection in Traveling-Wave Oscilloscopes

Record of Symp. on Electron, Ion, and Laser Beam Technol. (11th), 12-14 May, 1971, Boulder, CO 1971

The Measurement of Pulse Transition Duration

Proc., Union Radio Scientifique Internationale Comm. Symp.,

3-7 October, 1977, Lannion, France, pp. 159-164 1977

ANDREWS, J. R.; BELI, B. A.; BALDWIN, E. E.

Reference Flat Pulse Generator

NBS Tech. Note 1067

October 1983

ANDREWS, J. R.; NAHMAN, N. S .; BELL, B. A.

Status of Reference Waveform Standards Development at NBS

NBS SP 634, Proc., 1981 Seminar on Waveform Recorder Measurement Needs and Techn. for Evaluation/Calibration,

15 October, 1981, Boulder, CO, pp. 69-88 1982

ANDREWS, J.R.; WHITTEMORE, T.; MCCAA, W. D. Jr.

Survey of Present Waveform Sampling system Iimitations

NBS Rept. 10731

February 1972 
ANDREWS, J. R.; BELL, B. A.; NAHMAN, N. S .; BALDWIN, E. E. Reference Waveform Flat Pulse Generator 1982 CPEM Conf. Dig., June, 1982 1982

IEEE Trans. Instrum. Meas., Vol. IM-32, No. 1, pp. 27-32 March 1983

BOUILLE, R.; ANDREWS, J.R.

Measurement of Broadening of Pulses in Glass Fibers

Electron. Lett., Vol. 8, pp. 309-310

June 1972

ERSTROM, M. P.; MCCAA, W. D. Jr.; NAHMAN, N. S.

The Measured Time and Frequency Response of a Miniature Superconducting Coaxial Line

IEEE Trans. Nucl. Sci., NS-18, pp. 18-25

October 1971

GANS, W. L.

Present Capabilities of the NBS Automatic Pulse Measurement system

CPEM Dig., pp. 25-26 1976

IEEE Trans. Instrum. Meas., IM-25, pp. 384-388 December 1976

The Measurement and Deconvolution of Time Jitter in Equivalent-Time Waveform Samplers

IEEE Trans. Instrum. Meas., Vol. IM-32, No. 1, pp. 126-133 March 1983

Picosecond Pulse Measurements at NBS

Proc., 1985 Instrum. and Meas. Technol. Conf.,

20-22 March, 1985, Tampa, FL, pp. 142-144 1985

Picosecond Pulse Waveform Error Analysis at NBS

Proc., IEEE Spec. Issue on Radio Meas. Methods and Standards, pp. 86-90

January 1986

Dynamic Calibration of Oscilloscopes and Waveform Recorders Using Pulse Standards.

Record, Instrumentation \& Measurement Technology (IMTC) Conf.;

February 13-15, 1990; San Jose, CA; pp. 246-250. February 1990

GANS, W. L.; NAHMAN, N. S.

Pulse Testing of $R F$ and Microwave Components NBSIR 1973

July 1973

Shielded Balanced and Coaxial Transmission Lines - Parametric Measurements and Instrumentation Relevant to Signal Waveform Transmission in Digital Service NBSIR 81-1042

June 1981 
HOLT, D. R.; NAHMAN, N. S.

Coaxial Line Pulse-Response Error Due to a Planar Skin Effect Approximation

Proc., 1972 Conf. on Precision Electromagn. Meas.,

26-29 June, 1972, Boulder, CO, pp. 1-2 1972

IEEE Trans. Instrum. Meas., IM-21, pp. 515-519 November 1972

HONDA, T.; NABMAN, N. S.

A Dye Modelocked Nd+3 Glass Laser for Generating Electrical Reference Waveforms

NBSIR $74-360$

September 1972

Application of Ultrashort Optical Pulses to Electrical Pulse Measurements

Proc. Symp. on New Instrum., 28-29 January, 1974, IEE of Japan, Hokkaido University, pp. 29-38 1974

HUDSON, P. A.; ANDREWS, J. R.; BLANK, W.; ONDREJKA, A. R .

Investigation and Evaluation of Methods for Pulse Rise-Time Measurement Tech Report RADC-TR-68-207

October 1968

KANDA, M.

Time Domain Sensors and Radiators

Nat. Radio Science Meeting, January, 1982, University of Colorado, Boulder, CO 1982

LAWTON, R. A.

NBS SP 634 (Editor), Proc., 1981 Seminar on Waveform Recorder Measurement Needs and Techniques for Evaluation/Calibration, 15 October, 1981, Boulder, CO 1982

Precision Picosecond-Microsecond Electromagnetic Waveform Measurement at NBS

NBS SP $628 \mathrm{pp} .392-407$

June 1982

Performance Standards for Waveform Recorders

IEEE Trans. Nucl. Sci., Vol. NS-30, No. 1, pp. 263-266

February 1983

Photoconductive Switches Used for Waveform Generation at the National Bureau of standards

Proc., 1983 Picosecond Optoelectronics Conf., SPIE - The

International society for Optical Engineering, 24-26 August, 1983,

San Diego, CA, Vol. 439, pp. 88-94 1983 
LAWTON, R. A. (cont.)

An Efficient Antialiasing Filter

Dig., 1984 Conf. on Precision Electromagn. Meas., 20-24 August, 1984, Delft, The Netherlands, pp. 104-105 1984

IEEE Trans. on Instrum. and Meas., Vol. IM-34, No. 4, pp. 570-573

December 1985

Pulse Waveform Standards for Electro-optics

Proc., 1985 Topical Meeting on Picosecond Electronics and Opto-Electronics, 13-15 March, 1985, Lake Tahoe, NV,

pp. 205-206

1985

Status Report Transient Waveform Recorder Standard

Proc., 1985 Instrum. and Meas. Technol. Conf.,

20-22 March, 1985, Tampa, FL, pp. 154-155 1985

LAWTON, R. A.; ANDREWS, J. R.

Pulsed-Laser Application to Sampling Oscilloscope

Electron. Lett., Vol. 11, pp. 138

April 1975

Electrical Strobing of Photoconductor Cuts Sampling Oscilloscope's Risetime
Laser Focus, pp. 62-65
November 1976

LAWTON, R. A.; MEYER, K.

Waveform Standards for Electro-optics: A Pulse Duration Comparison

IEEE Trans. on Microwave Theory and Techn., Vol. MTT-35,

No. 4, pp. 450-453

April 1987

LAWTON, R. A.; NAHMAN, N. S .

Pyroelectric Detector Application to Baseband Pulse Measurements

Electron. Lett., Vol. 8, pp. 318-330

June 1972

LAWTON, R. A.; NAHMAN, N. S.; BIGELOW, J. M.

A Solid State Reference Waveform Standard

Dig., Instrum. and Meas. Technol. Conf., 17-18 January, 1984, Long

Beach, CA, pp. 74-76 1984

IEEE Trans. Instrum. Meas., Vol. IM-33, No. 3, pp. 201-205 September 1984

Reference Waveform Standard

Dig., IEEE Trans. Instrum. Meas., Vol. IM-33, No. 3,

pp. 201-205

September 1984 
LAWTON, R. A.; SCAVENNEC, A.

Photoconductive Detector of Fast-Transition Optical Waveforms Electron. Lett., Vol. 11, pp. 74-75 February 1975

LAWION, R. A.; YOUNG, M. Laser-Mode Beating Used for Detector Frequency-Response Measurements Appl. Opt., Vol. 16, pp. 2703-2705 October 1977

MCCAA, W. D. Jr.; NAHMAN, N. S .

Generation of Reference Waveforms by Uniform Lossy Transmission Lines IEEE Trans. Instrum. Meas., IM-19, pp. 382-390 November 1970

NABMAN, N. S. The Measurement of Baseband Pulse Rise Times of Less than $10^{-9}$ Second Proc., IEEE, Special Issue on Radio Meas. Methods and Standards, Vol. 55, No. 6, pp. 855-864 June 1967

Picosecond Domain Waveform Measurements (Japanese translation) Nikkei Electron., Nikkei-MCGraw Hill April 1979

Error Criteria and the Use of Reference Waveforms Proc. ATE Seminar/Exhib., January, 1981, Pasadena, CA, pp. IV.21-IV.28 1981

Error Criteria and the Use of Reference Waveforms Electron. Test, Vol. 4, No. 2, pp. 72-76 February 1981

Some Generic Waveform Recorder Problems NBS SP 634, Proc., 1981 Seminar on Waveform Recorder Measurement Needs and Techn. for Evaluation/Calibration, 15 October, 1981, Boulder, CO, pp. 1-5 1982

Picosecond Domain Waveform Measurements; Status and Future Directions IEEE Trans. Instrum. Meas., Vol. IM-32, No. 1, pp. 117-124 March 1983

Software Correction of Measured Pulse Data NATO ASI Series on Fast Electrical and Optical Meas., Vol 1, Series E, No. 108, pp. 351-417 1986

Picosecond-Domain Waveform Measurements

Proc., IEEE, Vol. 66, pp. 414-423 April 1978

NABMAN, N. S.; GUILLAUME, M. E.

Deconvolution of Duration Limited Waveforms

Dig. of Papers, URSI/U. S. National Radio Sci. Meeting, January, 1981, Boulder, CO, p. 86 1981 
NABMAN, N. S.; HOLT, D. R.

Transient Analysis of Coaxial Cables Using the Skin Effect Approximation $A+B$ (the square root of $s$ )

IEEE Trans. Circuit Theory, CT-19, pp. 443-451

September 1972

NAHMAN, N. S.; EKSTROM, M. P.; MCCAA, W. D. Jr.

Measured Time and Frequency Response of a Miniature Superconducting

Coaxial Line

Applied Superconductivity Conf., June, 1970, Boulder, Co 1970

PAULTER, N. G.; MAJUMDAR, A.

A New Proposed Triple Correlator for the Measurement of Ultrashort Laser Pulses

Optics Communications, Vol. 81, No. 1,2, pp. 95-100

February 1991

A New Triple Correlation Technique for Measuring Ultrashort Laser Pulses Review of Scientific Instruments, Vol. 62, No. 3, pp. 567-578 March 1991

RIAD, S. M.

The Deconvolution Problem: An Overview

Proc. of the IEEE, Special Issue on Radio Meas. Methods and

Standards, pp. 82-85

January 1986

RIAD, S. M.; NAHMAN, N. S.

Application of the Homomorphic Deconvolution for the Separation of TDR

Signals Occurring in Overlapping Time Windows

CPEM Dig., pp. 27-29

1976

IEEE Trans. Instrum. Meas., IM-25, pp. 388-391

December 1976

SCAVENNEC, A.; NAHMAN, N. S.

Active and Passive Mode Locking of Continuously Operating Rhodamine 6G

Dye Lasers

NBSIR 73-347

February 1974

YOUNG, M.; LAWTON, R. A.

Measurement of Pulsed-Laser Power

NBS Tech. Note 1010

February 1979 
ARTHUR, M. G.; REEVE, G. R.

Modulation Factor standards

NBS Tech. Note 1016

September 1979

BAIRD, R. C.

RF Measurements of the speed of Light

Proc., IEEE, Special Issue on Radio Meas. Methods and Standards, Vol. 55, No. 6, pp. 1032-1039 June 1967

BENSEMA, W. D.

Personal FM Transceivers

National Institute of Justice Standard-0209.01

September 1985

Mobile FM Transceivers

National Institute of Justice Technology Program, NIJ

Report -210.00

May 1986

BERRY, L. A.; FITZGERRELL, R. G.; VOGLER, L. E.

Investigation of Effect of Antenna Site and Antenna Type on LF

Non-Directional Beacon Performance

FAA-RD-73-174

1973

BOWMAN, $\boldsymbol{R}$. $\mathbf{R}$.

Self-Modulating Transducers

EOS-7039-Final

1968

A Temperature Probe for Radio-Frequency Heated Material

NBSIR 81-1634

January 1981

BRANDENBERGER, H.; HADORN, F.; HALFORD, D.; SHOAF, J . H .

High Quality Quartz Crystal Oscillators: Frequency Domain and Time Domain stability

Proc., 1971 Frequency Control Annual symp. (25th),

26-28 April, 1971, Atlantic City, NJ, pp. 226-234 1971

BUSSEY, H. E.; LARSEN, E. B.

Buried Antenna Performance: Development of Small Resonant Buried Antennas RADC-TR-74-169M, AD 783274

June 1974

CHEW, H.

Modeling of oil shale Retorts for Electromagnetic sensing Techniques NBSIR 81-1653

November 1981

Electromagnetic Modeling of oil shale Retorts for Remote sensing Purposes

IEEE Trans. Geosci. \& Remote Sensing, Vol. GE-20, No.4, pp. 510-517

October 1982 
CLARK, H. E.

Requirements for an Effective National Nonionizing Radiation Measurement System

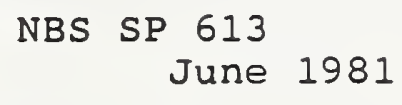

COLIIER, R. S.; CRUZ, J. E.; ELLERBRUCH, D. A.; LOWE, L. T.; WEITZEL, D. B. Instrumentation for Hydrogen Slush Storage Containers NASA-CR-119241 June 1971

NBS Rept. 9793 June 1971

DRIVER, L. D.; RIES, F. X.

A Wideband RF Voltage Comparator

Dig., 1980 Conf. Precision Electromagn. Meas. June 1980

ELLERBRUCB, D. A.

Microwave Methods for Cryogenic Liquid and Slush Instrumentation IEEE Trans. Instrum. Meas., Vol. IM-19, No. 4, pp. 412-416 November 1970

Application of Measurements of Electromagnetic Phenomena to Oceanography Proc., 1972 UJNR/MEC Symp. (1st), Record of the U.S.-Japan UJNR Joint Symp. on Marine Electronics, (Japanese Electrical Industrial Committee, Tokyo, Japan), 9 October, 1972, Tokyo, Japan, pp. 23-30 1972

Test Results for the Mooring Line Data Iine

NBSIR 73-341

October 1973

ELIERBRUCH, D. A.; BOYNE, H. S.

Active Microwave Water Equivalence Measurements

Proc., Ft. Collins snow Workshop 1980

FITZGERRELI, R. G.

Mobile Antennas

National Institute of Justice Standard-0205.01

May 1989

FOOTE, W. J.

A New Flange Design for O-Ring Seals

Rev. Science Instrum.

August 1970

GIBSON, R. A.; MILLER, C. K. S .

Bibliography of the Electromagnetic Fields Division Publications NBSIR 82-1673

August 1982

A Bibliography of the NBS Electromagnetic Fields Division Publications NBSIR 85-3022

April 1985 
GIBSON, K. A.; PAGE, J. M.; MILLER, C. K. S.

A Bibliography of the NBS Electromagnetic Fields Division Publications NBSIR 85-3040

$$
\text { February } 1986
$$

HALFORD, D.

Infrared-Microwave Frequency Synthesis Design: Some Relevant Conceptual Noise Aspects

Proc., 1971 Frequency Standards and Metrology Seminar,

30 August-1 September, 1971, Quebec, Canada, pp. 431-466 1972

HALFORD, D.; SHOAF, J. H.; RISLEY, A. S.

Spectral Density Analysis: Frequency Domain Specification and

Measurement of Signal Stability

1973 Annual Symp. on Frequency Control (27th),

12-14 June, 1973, Cherry Hill, NJ, pp. 421-431 1973

HAMILTON, C.; LLOYD, F.; PETERSON, R.; ANDREWS, J.R.

A Superconducting Sampler for Josephson Logic Circuits

Appl. Phys. Lett., Vol. 35, No. 9, pp. 718-719

November 1979

HAYES, R. E.; KANDA, M.; MASCLET, G.; MAY, W. G.

The Application of Semiconductors to Quasi-Optical Isolators for use at Submilimeter Wavelengths

NASA-CR-105980

July 1969

NASA-CR-86379

April 1970

HILL, D. A.

HF Ground Wave Propagation over Forested and Built-up Terrain

NTIA Report 82-114

December 1982

Book Review - Leaky Feeders and Subsurface Radio Communications IEEE Antennas and Propagat. Soc. News., Vol. 25, No. 3, pp. 23-24

June 1983

HILL, D. A.; WAIT, J.R.

Propagation Along a Coaxial Cable with a Helical Shield

IEEE Trans. Microwave Theory Technol., Vol. MTT-28, No. 2, pp. $84-89$

February 1980

Electromagnetic Theory of the Loosely Braided Coaxial Cable: Part II Numerical Results

IEEE Trans. Microwave Theory Technol., Vol. MTT-28, No. 4, pp. 326-331

April 1980 
HILI, D. A.; WAIT, J.R. (cont.)

Ground Wave Attenuation Function for a Spherical Earth with Arbitrary Surface Impedance Radio Science

Radio science, Vol. 15, No. 3, pp. 637-643

May-June 1980

On the Excitation of the Zenneck Surface Wave Over the Ground at $10 \mathrm{MHz}$ Annales des Telecommunications, Vol. 35, Nos. 5-6, pp. 1-4 May-June 1980

Electromagnetic Characteristics of a Coaxial Cable with Periodic slots IEEE Trans. Electromagn. Compat., Vol. EMC-22, No. 4, pp. 303-307 November 1980

HF Ground Wave Propagation over sea Ice for a Spherical Earth Model

IEEE Trans. Antennas Propagat., Vol. AP-19, No. 3, pp. 525-527 May 1981

HF Ground Wave Propagation over Mixed Land, Sea, and Sea-Ice Paths IEEE Trans. Geosci. \& Remote Sensing, Vol. GE-19, No. 4, pp. 210-216 October 1981

HF Radio Wave Transmission over Sea-Ice and Remote Sensing Possibilities IEEE Trans. Geosci. \& Remote Sensing, Vol. GE-19, No. 4, pp. 204-209

October 1981

Ground Wave Propagation over a Mixed Path with an Elevation Change IEEE Trans. Antennas Propagat., Vol. AP-30, No. 1, pp. $139-141$ January 1982

JESCH, R. L.

Evaluation of Low-Loss/Low-Reflection Two-Port Devices or Adapters by Automated Measurement Techniques NBSIR 78-870 December 1977

Dielectric Measurements of Oil Shale as Functions of Temperature and Frequency NBSIR 83-1683 January 1983

Measured Vehicular Antenna Performance

IEEE Trans. Veh. Technol., Vol. VT-34, No. 2, pp. 97-107 May 1985

Personal/Mobile FM Transceivers

National Institute of Justice Technology Program, NIJ Report-0224.00 May 1986

Fixed and Base Station FM Transmitters National Institute of Justice Standard - 0201.01 September 1987 
JESCH, R. L. (cont.)

Fixed and Base Station FM Receivers

National Institute of Justice Standard-0206.01 July 1988

JESCH, R. L.; BERRY, I. S. Batteries used with Law Enforcement Communications Equipment NBS Rept. 10722 October 1971

JESCH, R. L.; HOER, C. A.

Characterization of a High Frequency Probe Assembly for Integrated Circuit Measurements

NBS Tech. Note 663

January 1975

JESCH, R. L.; BAILEY, R. A.; TAUSCH, H. J .

Characterization of A H.F. Probe for Integrated Circuits Measurements Proc., Government Micro-Circuit Applications Conf.,

25-27 June, 1974, Boulder, CO, pp. 120-121 1974

JICKLING, R. M.; SHAFER, J.F.

Repeaters for Law Enforcement Communication Systems-Law Enforcement Standard Program

Law Enforcement Standards Laboratory RPT-0206.00

October 1974

FM Repeater Systems

National Institute of Law Enforcement and Criminal Justice, STD -0213.00 November 1977

JONES, R. N.

A Comparison of Centrifuge and Freezing Calorimeter Methods for Measuring Free Water in Snow NBSIR 79-1604

April 1979

Evaluation of Three-Terminal and Four-Terminal Pair Capacitors at High Frequencies

NBS Tech. Note 1024

September 1980

RANDA, M.

Non-Reciprocal Devices Using Solid State Magnetoplasmas at Millimeter and Submillimeter Wavelengths NASA-CR-122923

August 1971

KANDA, M.; MAY, W. G.

Hollow-Cylinder Waveguide Isolators for use at Millimeter Wavelengths NASA-CR-140760

November 1974

Reflection Beam Isolator for Submillimeter Wavelength NASA-CR-140761

June 1975 
RERNS, D. M.

Scattering-Matrix Description and Near-Field Measurements of

Electroacoustic Transducers

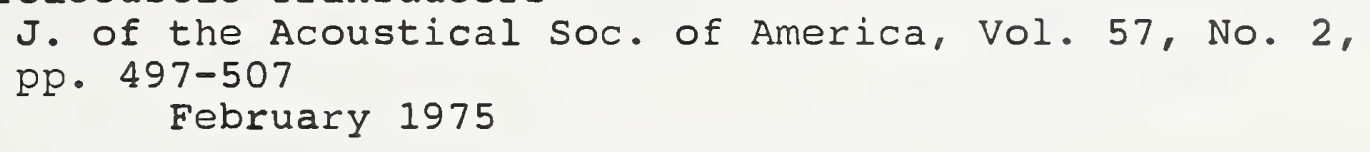

RING, J.; PEISER, H. S.; SANGSTER, R. C.

Guidelines for Specification and Procurement of Measurement

Instrumentation

NBSIR $78-891$

June 1978

KUFFEL, J.; MALEWSKI, R.; VAN HEESWIJK, R.; LAWTON, R. A.

Dynamic Performance of Digital Recorders Used for Monitoring High

Voltage Impulse Tests

Proc., 1985 Instrum. and Meas. Technol. Conf.,

20-22 March, 1985, Tampa, FL, pp. 211-215

1985

LARSEN, N. T.; VECCHIA, D. F.; SUGAR, G . R.

VOR Calibration Services

NBS Tech. Note 1069

April 1985

LAWTON, R. A.; ANDREWS, J. R.

Optically Strobed Sampling Oscilloscope

IEEE Trans. Instrum. Meas., 25, pp. 56-60

March 1976

LEWIS, R. L.

The Wave-Hop Fields for an Inclined Dipole over a Spherical Earth with an Anisotropic Ionosphere

OT-ITR-RR5

October 1970

Spherical Scanning Data Processing: An Algorithm for Halving the Data Processing Effort When the Radiation into the Back Hemisphere is Negligible

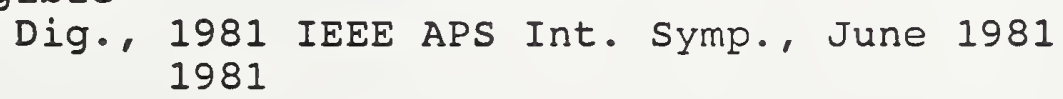

IITTLE, W. E.

Automated Computer Controlled Measurements

Proc., 1974 Conf. on Precision Electromagn. Meas., 1-5 July, 1974, London, England 1974

LYONS, R. M.; GIBSON, K. A.

A Bibliography of the NIST Electromagnetic Fields Division Publications NISTIR 89-3920

September 1989

A Bibliography of the NIST Electromagnetic Fields Division Publications NISTIR 3945

August 1990 
MANNEY, C. H.

Applicability of Speech Bandwidth Compression Techniques in Mine

Electromagnetic Communications

NBS Rept. 10728

February 1972

MILLER, C. K. S.

Millimeter Wave Metrology Capabilities at NBS

Proc., 1974 Millimeter Waves Techniques Conf.,

26-28 March, 1974, San Diego, CA, p 11. 1974

A Bibliography of Publications in the NBS Electromagnetic Fields Division

NBSIR 80-1635

November 1980

MONTGOMERY, J. P. ; CHANG, D. C .

Electromagnetic Boundary-Value Problems Based Upon a Modification of

Residue Calculus and Function Theoretic Techniques

NBS MN 164

June 1979

NAHMAN, N. S.; ALLRED, C. M.; ANDREWS, J. R.; HOER, C. A.; LAWTON, R. A. Radar Absorber Measurement Techniques at Frequencies Above $20 \mathrm{GHz}$ NBSIR 79-1613

August 1979

NELSON, R. E.

A Guide to Voice Scramblers for Law Enforcement Agencies

NBS SP $480-8$

December 1976

NELSON, R. E.; JICKLING, R. M.

Control Cable Assemblies Used with Mobile FM Receivers

National Institute of Justice, NIJ Std-0216.00

December 1981

REIDY, A. R.; GIBSON, K. A.

A Bibliography of NIST Electromagnetic Fields Division Publications NISTIR 88-3900

September 1988

ROE, R. C.; WITTMANN, R. C.

Improved Coal Interface Detector

NBSIR 82-1663

May 1982

ROGERS, G. J.; SAWYER, D. E.; JESCH, R. L.

Semiconductor Measurement Technology: Measurement of Transistor

Scattering Parameters

NBS SP 400-5

January 1975 
SANGSTER, R. C.

Relevancy of Measurements by a systems Approach

Proc., 1972 Joint Meas. Conf., 21-23 June, 1972, Boulder, Co, pp. 31-37

1972

Trans. Matrix Description of the National system of Physical

Measurements

NBSIR 75-943

August 1976

Collected Executive Summaries: Studies of the National Measurement

System $1972-75$

NBSIR 75-947

September 1976

Study of the National Measurement system. Final Summary Report, $1972-75$ NBSIR 75-925

December 1976

Collected Executive Summaries: Studies of the National Measurement system

NBSIR 75-947-Rev. S.

February 1978

SCA:YENNEC, A.; NAHMAN, N. S .

A Simple Passively Mode-Locked CW Dye Laser

IEEE J. Quantum Electron., Vol. QE-10, pp. 95-96 January 1974

scoTT, W. W., Jr.

New Coaxial RF-DC Ammeter

IEEE Trans. Instrum. Meas., Vol. IM-19, No. 4, pp. 318-323 November 1970

Batteries Used with Law Enforcement Communications Equipment: Chargers and Charging Techniques

NBS Rept. 10732

June 1973

STOLTENBERG, R. E .

RF Null Detector NBS/SND

NBSIR 73-302

June 1973

Detection of Human Intruders by Low Frequency Sonic Interferometric

Techniques

NBSIR $74-364$

May 1974

STOLTENBERG, R. E.; WITTMANN, R. C.

Acoustical Interferometer Wader AIW Final Report of Advanced Development Test and Evaluation

NBSIR 82-167(R)

June 1982 
TAGGART, H. E.; WORKMAN, J. L.; NELSON, R. E.

Emergency Locator Transmitters: Effective Radiated Power Levels and Techniques of Determining Effective Radiated Power NBS Rept. 9769

February 1971

VANZURA, E. J.

Creating CSUBs written in FORTRAN That Run in BASIC Proc., INTEREX Technical Computer Users Conf., 7-12 August, 1988, Orlando, FL, paper 20, pp. 1-18 1988

Creating cSUBs in BASIC, Part I HP Design and Automation Magazine, pp. 18-21 october 1988

Creating CSUBs in Basic, Part II

HP Design and Automation Magazine, p. 25 November 1988

WACKER, P. F.; CORD, M. S .; BURKHARD, D. G.; PETERSEN, J. D.; KUKOL, R. F. Microwave spectral Tables, Volume III, Polyatomic Molecules with Internal Rotation NBS MN 70, Vol $3.3, p .276$ June 1969

WAIT, D. F.; BEATTY, R. W.

The 1973 Int. Microwave Symp.

IEEE Trans. Microwave Theory Technol., Vol. MTT-21, No. 12, pp. 747-751

December 1973

WAIT, J.R.; HILI, D. A.

Fields of a Horizontal Loop of Arbitrary Shape Buried in a Two-Layer Earth

Radio Science, Vol 15, No. 5, pp. 903-912

September-October 1980

WAKEFIELD, J. P.

Addendum to Earth Terminal Measurement System Maintenance Manual NBSIR 81-1641

October 1981

WEIDMAN, M. P.; CAMPBELI, E.

A Method for Designing Multi-Screw Waveguide Tuners NBS Tech. Note 393

October 1970

WEITZEL, D. H.; LOWE, L. T.; ELLERBRUCH, D. A.; CRUZ, J. E.; SINDT, C. F. Hydrogen Slush Density Reference System

NBS Rept. 9796

June 1971

NASA-CR-124764

June 1974 
WHARTON, M. J.; FRUSH, C. L.; NAHMAN, N. S.

A Video Recorder for Coherent Doppler Radar

IEEE Trans. Geosci. Electron., Special Issue on Radio Metrology, GE-17, No. 4, pp. 171-178

October 1979

WIIDHACK, W. A.; MASON, H. L.; POWERS, R. S. Jr.

Accuracy Charts for RF Measurements

Proc., IEEE, Special Issue on Radio Meas. Methods and Standards, Vol. 55, No. 6, pp. 1056-1063

June 1967

WYSS, J. C.; ANSON, W. J.; ORR, R. D.

Building Penetration Project

NBSIR 84-3009

September 1984

WYSS, J. C.; STWALLEY, W. C.; KOCH, M. E.; VERMA, K. K.

Laser Fluorescence Diagnostics of Lithium Vapor for Inertial confinement Applications

Topical Meeting on Inertial Confinement Fusion, February 1980, San Diego, CA 1980

YAGHJIAN, A. D.

Theory of Adjoint Reciprocity for Electroacoustic Transducers

NBSIR 73-329

February 1974

Direct Integration of the Field Equations for Electroacoustic

Transducers

IEEE Letters, Vol. 62, No. 6, pp. 858-859

June 1974

A Direct Approach to the Derivation of Electric Dyadic Green's Functions AP-Symposium Dig., October, 1976, pp. 76-156 October 1976

NBS Tech. Note 1000

January 1978

Electric Dyadic Green's Functions in the Source Region

Proc., IEEE, Vol. 68, No. 2

February 1980

Augmented Electric- and Magnetic-Field Integral Equations

Dig., Int. URSI Symp. on EM Waves, Munich Germany August 1980

Radio Science, Vol. 16, No. 6, pp. 987-1001

November-December 1981

Reply to Criticism on Electric Dyadic Functions in the Source Region Proc., IEEE, Vol. 69, No. 2 February 1981 
YAGHJIAN, A. D. (cont.)

A Delta-Distribution Derivation of the Electric Field in the source Region

Dig., 1981 IEEE/AP-S Symp.

YOUNG, M.; LAWTON, R. A.

Saturation of Optical Detectors at High Modulation Frequency

Proc., Annual Meeting Opt. Soc. of America, 12 october, 1977, Toronto, Canada, Vol. $67, \mathrm{p} .1398$ 1977

ZAPF, T. L.; HARVEY, M. E.; LARSEN, N. T.; STOLTENBERG, R. E.

Ultrasonic Calorimeter for Beam Power Measurements from 1 to 15 Megahertz

NBS Tech. Note 686

September 1976

Proc., 1976 Ultrasonics Symp., 29 September-1 October, 1977, Annapolis, MD, IEEE Cat 76, CH1120-5SU, pp. 573-576

1977 
ADAIR, R. T. ADAMS, J. W. AGEE, D. A. $A G Y, D$. L. ALLRED, C. M. ALSPACH, W. J . ANDERSON, $\mathrm{L}$. $R$ 。 ANDERSON, $W$. T. ANDREWS, $J$. R. ANSON, $W$. $J$. ARTHUR, M. G. BABJI, $T$. BACHMAN, D. D. BAILEY, R. A. BAIRD, R. C. BAKER-JARVIS, J . BALDWIN, E. E. BEAN, J . L. . BEATTY, R. W. BELL, B. A. BELSHER, D. R. BENNETT, W. S. BENSEMA, $W$. D. BEREUTER, W. A. BERRY, I. S. BERRY, L. A. BIGELOW, J. M. BLACKBURN, D. BLANK, $W$. BORSERO, $M$. BOUILLE, R. BOWMAN, $R$. $R$. BOYLE, D. R. BOYNE, H. S.

BRANDENBERGER, $\mathrm{H}$. BREMER, T. H. BUCHHOLZ, F. IM. BUDLONG, A. ' BUSSEY, H. E. CAMELL, D. G. CAMPBELL, E. CANALES, $S$. CAVCEY, K. H. CHANG, A. T. C. CHANG, D. C. CHEW, $\mathrm{H}$. CLAGUE, F. R. CLARK, H. E. COLLIER, R. S. COOK, C. C. CORD, M. S. COUNAS, G. J. CRAWFORD, M. L. CRUZ, J. E. DAY, G. W.
$24, \dot{26}, 33^{\circ}, 39,40,45,46,48,49,54,66,68$ $24,26,33,39,40,45,46,48,49,52,77,79$ 54,60 $54,55,58,61,65,66,94$ $\cdot . \cdot . \cdot . . .0 .25$

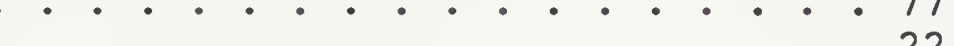
$10,2 \dot{5}, 4 \dot{1}, 4 \dot{2}, 7 \dot{9}, 8 \dot{1-85}, \dot{90}, \dot{93}, 94$ . . . . . . . . . 18, 27, 97 $25,43,67,71,74,88$ ............... . . . 16,48

. . . . . . . . . . . . . . 21 92 $\dot{3}, \dot{5}, \dot{14}, \dot{15}, \dot{25}, 88$ $\cdot \cdot \cdot \cdot \cdot 20$ $25,42,79,82,83$ $\therefore \quad . \quad 54,96$ - . 82,83 $25,40,76,77$ $3 . \bullet \cdot \bullet \cdot \bullet-\bullet 0$ $3,24,26,40,41,44,48,88$ 92 88 85 67 84 41 $26,27, \dot{33}, \dot{50}, 88$ . . . . . 71 $21,76,77,89$ 88 71 75 24 96 $3,20-22,76,77,88$ $3,27,42$
$65,69,73,96$ $65,69,73,96$ $7,27,79$ . . . . . . . . . . . . . . 76 $6,9,17,42,44,48-50,52,76,78,94$ - 76,88 $54,55,71$ - 27,89 76,89 
DAYWITT, W. C.

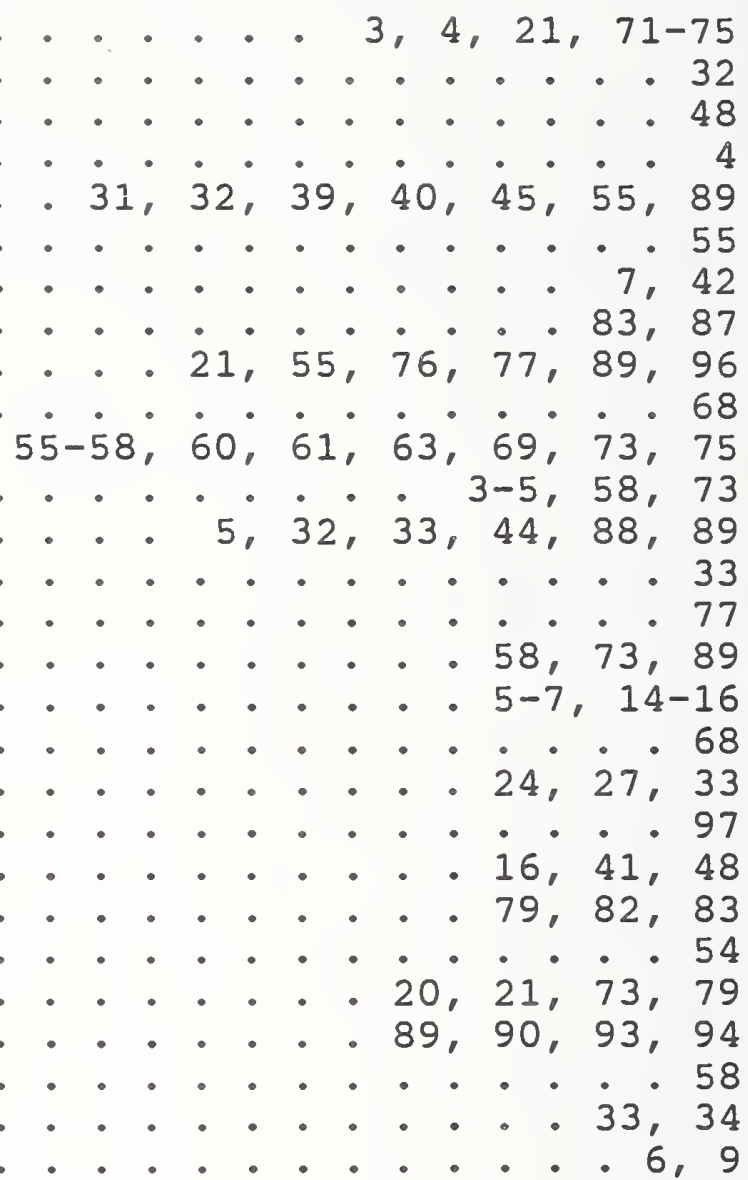

DECKER, W. F.

DOBROSKI, H. 48

DOUGHERTY, H. T.

DRIVER， L. D.

EBBESEN, H.

EHRET, R. L.

EKSTROM， M. P.

ELLERBRUCH, D. A.

ELWELL, L. B.

ESTIN, A. J.

FITZGERRELL，R. G.

FLANIGAN, W. F. Jr.

FLEMING R. $W$.

FOOTE, W. J.

FRANCIS, M. H.

FREDERICK, N. V.

FRIDAY, D. S.

FRUSH, C. L.

GALLIANO, P. G.

GANS, W. L. .

GATTERER, L.

GIBSON, K. A.

GINLEY, R. A.

GREENE, F. M.

GRIMM, K. R.

GROSVENOR, J. H.

GUERRIERI， J. R.

GUILLAUME, M. E.

HADORN, F.

HALFORD, D.

HAMILTON, C.

HARVEY, M. E.

HAYES, R. E.

HEIM, L.

HIESTER, A. E.

HILL, D. A.

HOER, C. A.

- 14

HOLT, D. R.

22,79

6,14

HONDA, T.

HUDSON, P. A.

HUNTER, R. D.

HUNTLEY, L. E.

JANEZIC, M. D.

JESCH, R. L.

JICKLING, R. M.

JOHNSON, R. B.

JONES, R. N.

JUDISH, R. M.

JUROSHEK, J.R.

KAISER, R. K. F.

KAMPER, R. A.

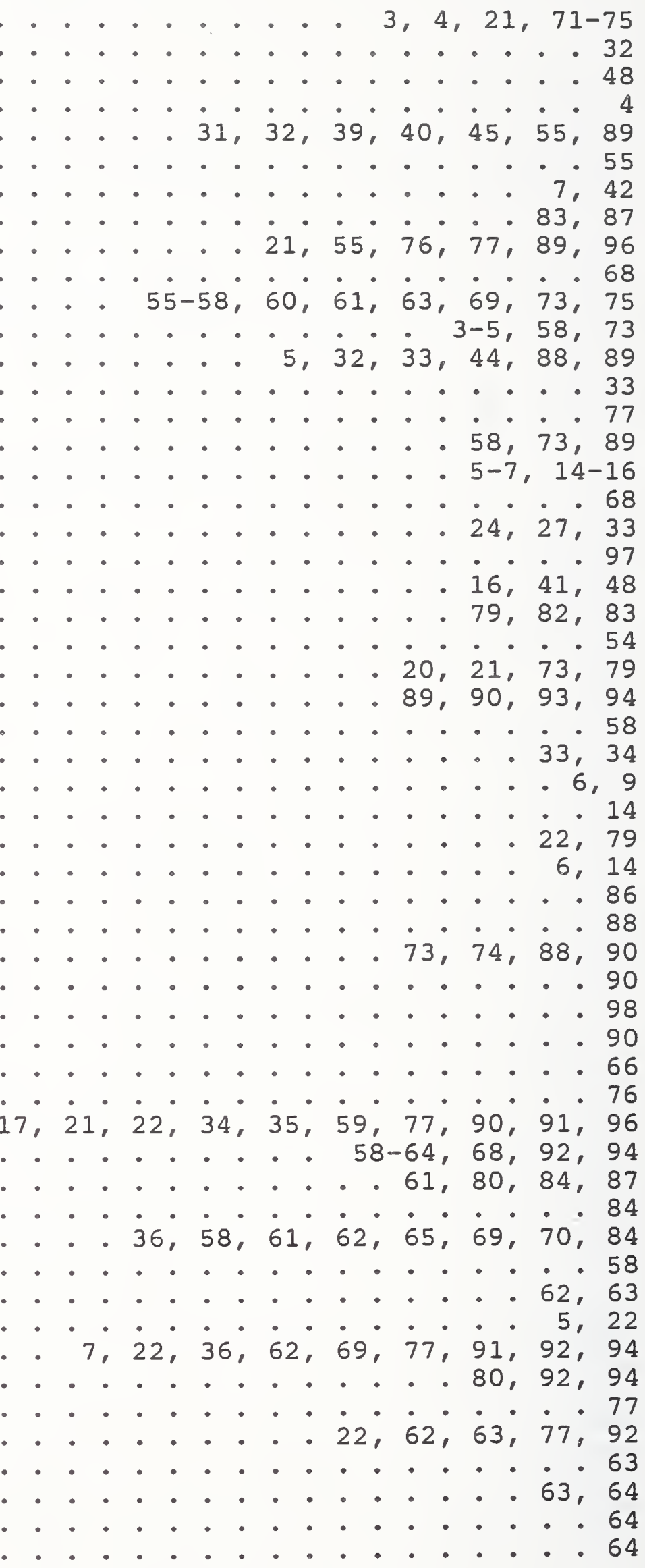


KANDA, M. . . 4, 6-9, 18, 22, 24, 26, 31, 32, 36-41, 44-47, 52, 53, 64, 71,

KERNS, D. M.

KESSEL, W.

KING, J .

KISSICK, W. A.

KLEMPERER, W. K

$\mathrm{KOCH}, \mathrm{M}$. E.

KOEPKE, G. H.

KREMER, D. P .

KUFFEL, J.

KUKOL, R. F.

LADBURY, J. M.

LARSEN, E. B.

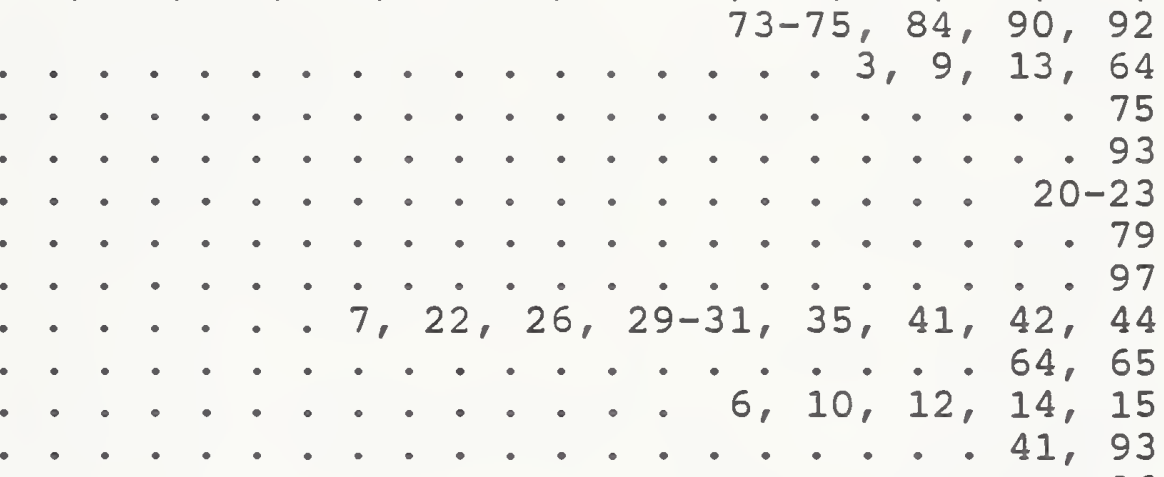

LARSEN, N. T.

LARSON, T. R.

LARSON, W.

LEWIS, R. L.

LITTLE, $W . E$.

LIU, B. H.

LIVINGSTON, E. M.

$\cdot \cdot \cdot \cdot \cdot \cdot \cdot \cdot 30,31,52$

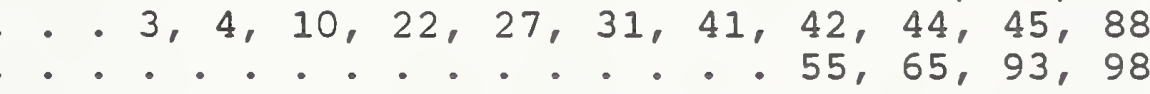

LLOYD, F.

LOWE, I. T.

LOWELL, W. R.

LUFT, P. E.

LYONS, R. M.

MA, M. T.

MACREYNOLDS, $K$.

MAJOR, J. R.

MAJUMDAR, A.

$10,2 \dot{2}, 4 \dot{1}, 4 \dot{2}, 6 \dot{5}, 7 \dot{9}, 8 \dot{2}, 84-87,93,94,98$

MALEWSKI, R.

MANNEY, C. H.

MARKS, R. B.

MARLER, F. E.

$21,22,66,93$

MARTZLOFF, F. D .

MASCLET, G.

MASON, H. I.

MASTERSON, K. D

MAY, W. G. •

MCCAA, W. D. Jr.

i1, $i 7, \dot{1}, \dot{1}, 41-4 \dot{4}, 4 \dot{8}, 5 \dot{0}-52$

MCFARLANE, E. J.

MCLAUGHLIN, R. G

MEDLEY, H. W.

MELQUIST, D. G .

METZKER, R. F.

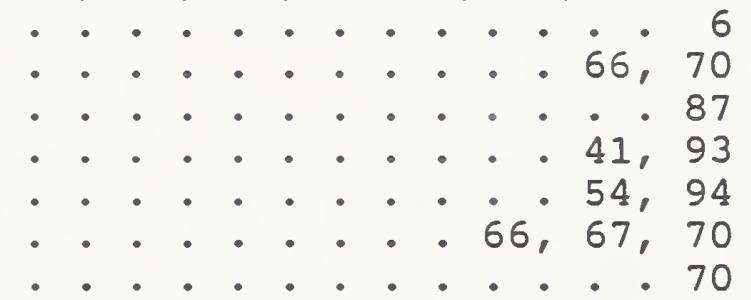

MEYER, $K$.

MIERS, T. - .

MILLER, C. K. S.

MONTGOMERY, J. P.

MORGAN, W. L.

MORRIS, D.

MUTH, L. A.

. . . . 44

44
90

NAHMAN, N. S.

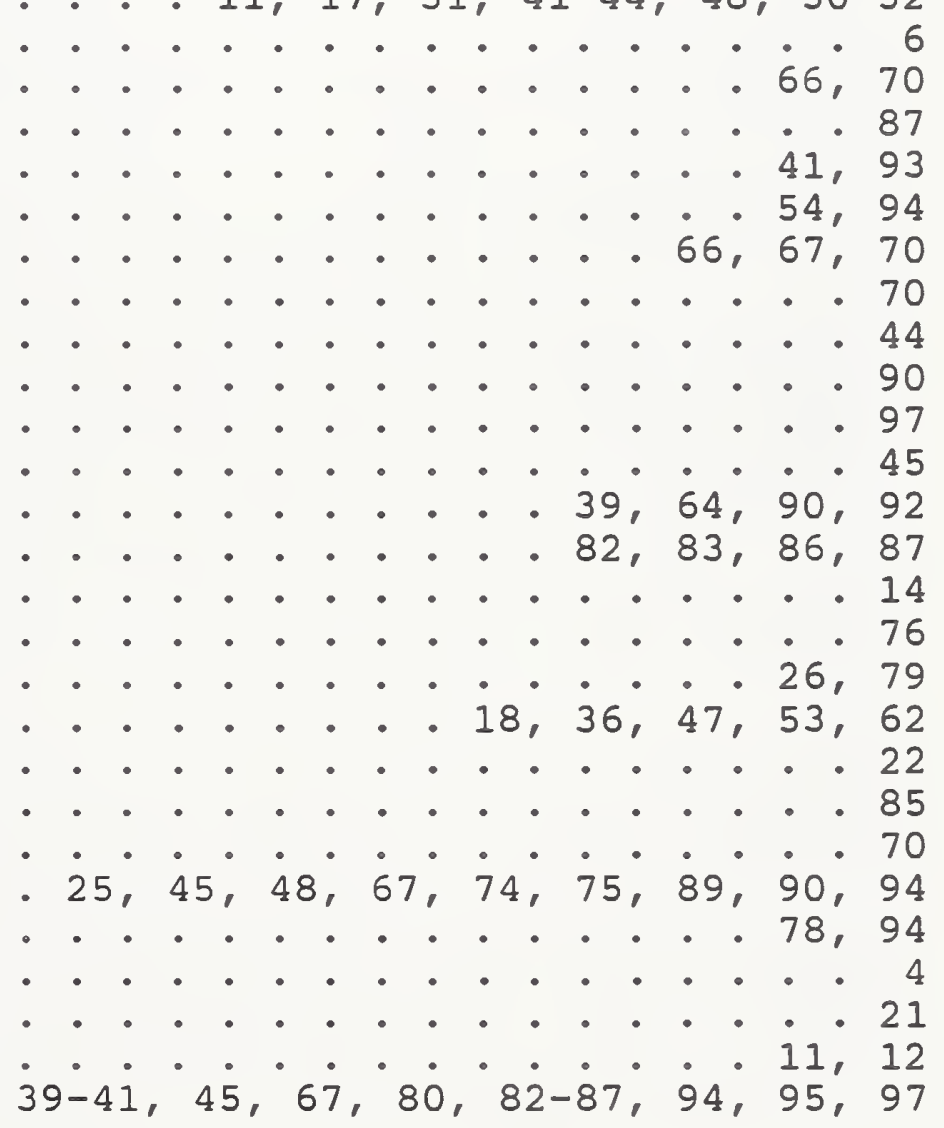


NELSON, R. E.

NEWELI, A. C.

NORGARD, J. D.

ONDREJKA, A. R.

ORR, R. D.

PAGE, J. M.

PAULTER, N. G.

PEISER, H. S.

PERERA， $S$.

PERSINGER, $R$. R.

PETERSEN, J. D.

PETERSON, R.

PHILIIPS, K. R.

POWERS, R. S. Jr.

RANDA, J. P.

REBULDELA, G.

REEVE, G. R.

REIDY, A. R.

REPJAR, A. G.

RIAD, S. M. '

RIDDLE，B. F.

RIES, F. X.

RISLEY, A. S.

ROE, K. C.

ROGERS, E. H.

ROGERS, G. J.

ROGERS, J. E.

RUMFELT, A. Y.

RUSSELL, D. H.

SANGSTER, R. C.

SAULSBERY, L. F.

SAWYER, D. E.

SCAVENNEC, A.

SCOTT, W. W., Jr.

SEGA, R. M.

SELBY, M. C.

SEQUEIRA, H. B.

SHAFER, J. F. .

SHEERAN, S.

SHERWOOD, G. V.

SHIUE, J. C.

SHOAF, J. H.

SIMPSON, P. A.

SINDT, C. F.

SLADEK, M. J.

SMART, G. R.

SPAULDING, A. D.

SPECIALE, R. A.

SPIESS, W.

SREENIVASIAH, I.

STEPPE, M. C.

STILES, J. A.

STOKES, R. W.

STOLTENBERG, R. E.

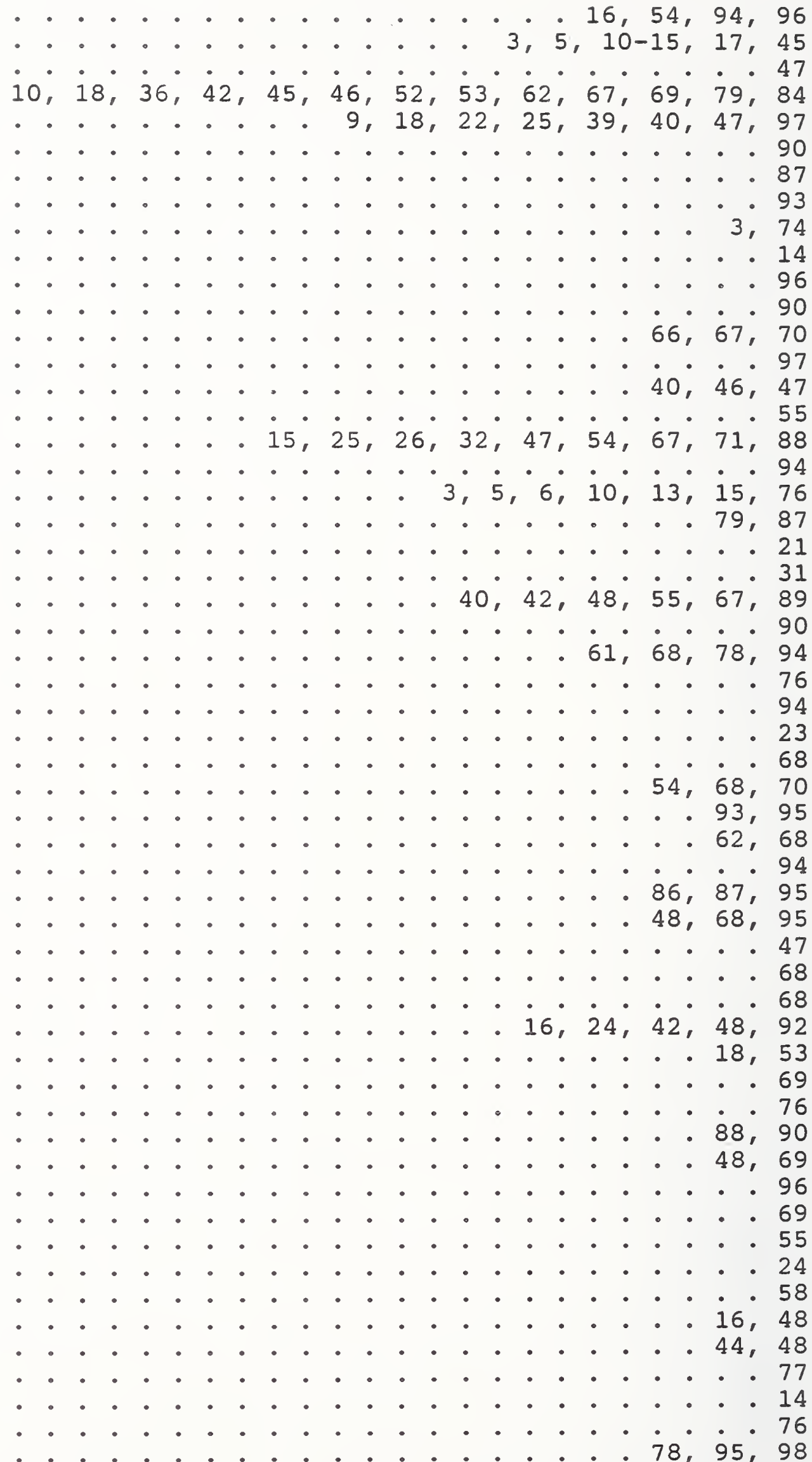


Author Index (cont.)

Name

Page Ref.

STUBENRAUCH, C. F. . . . . . . . . . . . . . . . 3-6, 13-16, 18, 48

STWALLEY, W. C. . . . . . . . . . . . . . . . . . . . . . . . . . 97

SUGAR, G. R. . . . . . . . . . . . . . . . . . . . . . . . . . 93

TAGGART, H. E. . . . . . . . . . . . . . . . 16, 20, 24, 48, 49, 96

TAMURA, D. T. . . . . . . . . . . . . . . . . . . . . . . . . . 15

TAUSCH, H. J. . . . . . . . . . . . . . . . . . . . . . . . . 92

THOMAS, C. L. . . . . . . . . . . . . . . . . . . . . . . . . 30, 31

TIPPET, J. C. . . . . . . . . . . . . . . . . . . . . . . . . . 49

TOMOEDA, N. C. . . . . . . . . . . . . . . . . . . . . . . . . . . 24

TREADO, M. J. . . . . . . . . . . . . . . . . . . . . . . . . . . 16

TRYON, P. V. . . . . . . . . . . . . . . . . . . . . . . . . 65

VAN HEESWIJK, R. • . . . . . . . . . . . . . . . . . . . . . . 41, 93

VANZURA, E. J. . . . . . . . . . . . . . . . . . . 20, 23, 24, 49, 96

VECCHIA, D. F. . . . . . . . . . . . . . . . . . . . . . . . . 93

VERMA, K. K. . . . . . . . . . . . . . . . . . . . . . . . . . . . . 97

VOGLER, L. E. . . . . . . . . . . . . . . . . . . . . . . . . 88

WACKER, P. F. . . . . . . . . . . . . . . . 14, 16, 17, 49, 50, 96

WAINWRIGHT, A. E. . . . . . . . . . . . . . . . . . . . . 15, 47

WAIT, D. F. . . . . . . . . . . . . . . . . . 3, 17, 71, 74, 75, 96

WAIT, J. R. . . . . . . . . . . . . . . 7, 17, 35, 59,90,91,96

WAKEFIELD, J. P. • . . . . . . . . . . . . . . . . . 66, 75 , 96

WEIDMAN, M. P. . . • • . . . . • . . . . . . . . . . 69, 70, 96

WEIL, C. M. . . . . . . . . . . . . . . . . . . . 21, 22, 70

WEITZEL, D. H. . . . . . . . . . . . . . . . . . . . . . 89, 96

WERNER, P. E. . . . . . . . . . . . . . . . . . . . . . . . 36, 62

WHARTON, M. J. . . . . . . . . . . . . . . . . . . . . . . . . . 97

WHITTEMORE, T. . . . . . . . . . . . . . . . . . . . . . . . . . 82

WILDHACK, W. A. . . . . . . . . . . . . . . . . . . . . . . 97

WILLIAMS, D. F. . . . . . . . . . . . . . . . . . . . . 67, 70

WILSON, P. F. . . . . . . . . . . . . . . . . . . 17, 44, 50-52

WILSON, W. A. . . . • . . . . . . . . . . . . . . . . . . . . 32

WITTMANN, R. C. . . . . . . . . . . . . . . . 11, 18, 19, 78, 94, 95

WOODRUFF, J. J. . . . . . . . . . . . . . . . . . . . . . . . . . 4

WORKMAN, J. I. . . . . . . . . . . . . . . . . . 16, 30, 31, 96

WU, D. I. . . . . . . . . . . • . . . . . . . . . . . . 24, 52

WU, Y. • . . . . . . . . . . . . . . . . . . . . . . . . . . . . 24

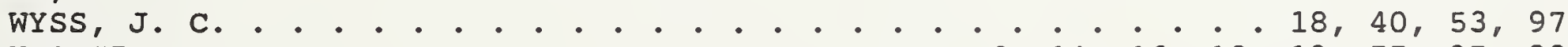

YAGHJIAN, A. D. . . . . . . . . . . . . 6, 14, 16, 18, 19, 77, 97, 98

YATES, B. C. . . . . . . . . . . . . . . . . . 55, 66, 68, 70

YODOSHIMA, I. . . . . . . . . . . . . . . . . . . . . . . . . . 41

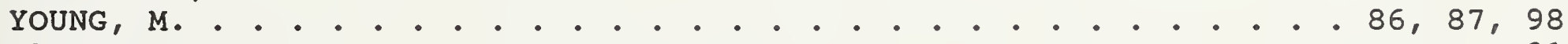

ZALTSMAN, E. B. . . . . . . . . . . . . . . . . . . . . . . . . . 21

ZAPF, T. L. . . . . . . . . . . . . . . . . . . . . .66, 98 


\section{BIBLIOGRAPHIC DATA SHEET}

2. PERFORMING ORGANIZATION REPORT NUMBE

3. PUBLCATION DATE

4. TITLE AND SUBTITLE

A Bibliography of the NIST Electromagnetic Fields Division Publications

5. AUTHOR(S)

Ruth Marie Lyons; Kathryn A. Gibson (Editors)

6. PERFORMING ORGANIZATION (IF JOINT OR OTHER THAN NIST, SEE INSTRUCTIONS) U.S. DEPARTMENT OF COMMERCE NATIONAL INSTITUTE OF STANDARDS AND TECHNOLOGY BOULDER, COLORADO 80303-3328

7. CONTRACT/GRANT NUMBER

8. TYPE OF REPORT AND PERIOD COVERED

9. SPONSORING ORGANIZATION NAME AND COMPLETE ADDRESS (STREET, CITY, STATE, ZIP)

10. SUPPLEMENTARY NOTES

Supersedes NISTIR 3945

11. ABSTRACT (A 200-WORD OR LESS FACTUAL SUMMARY OF MOST SIGNIFICANT INFORMATION. IF DOCUMENT INCLUDES A SIGNIFICANT BIBLIOGRAPHY OR LITERATURE SURVEY, MENTION IT HERE.)

This bibliography lists the publications by the staff of the Electromagnetic Fields Division of the National Institite of Standards and Technology for the period January 197 through July 1991. It supersedes NISTIR 3945, which Iisted the publications of the Electromagnetic Fields Division from January 1970 through July 1990. Selected earlier publications from the Division's predecessor organizations are included.

12. KEY WORDS (6 TO 12 ENTRIES; ALPHABETICAL ORDER; CAPITALZE ONLY PROPER NAMES; AND SEPARATE KEY WORDS BY SEMICOLONS) antennas; dielectric measurements; electromagnetic interference; microwave metrology; microwave power, impedance, attenuation; near-field antenna measurements; noise; non-ionizing radiation; radiation hazards; standards; time domain; waveform metrology

13. AVAILABILITY

\section{$\mathrm{X}$ UNLIMITED}

FOR OFFICIAL DISTRIBUTION. DO NOT RELEASE TO NATIONAL TECHNICAL INFORMATION SERVICE (NTIS).

ORDER FROM SUPERINTENDENT OF DOCUMENTS, U.S. GOVERNMENT PRINTING OFFICE, WASHINGTON, DC 20402.

$X$ ORDER FROM NATIONAL TECHNICAL INFORMATION SERVICE (NTIS), SPRINGFIELD, VA 22161.
14. NUMBER OF PRINTED PAGES

108 




(16) 
